WSRC-TR-2006-00458

M\&O-PUD-2006-00101

Revision 0

Revision 0

\title{
Pu Immobilization - Induction Melting and Offgas Testing
}

\author{
T.M. Jones, J.R. Zamecnik, D.H. Miller, D.T. Herman, and J.C. Marra
}

November 2006

Process Science \& Engineering

Savannah River National Laboratory

Aiken, SC 29808

Prepared for the U.S. Department of Energy Under Contract Number 


\title{
DISCLAIMER
}

This report was prepared by Washington Savannah River Company (WSRC) for the United States Department of Energy under Contract No. DE-AC09-96SR18500 and is an account of work performed under that contract. Neither the United States Department of Energy, nor WSRC, nor any of their employees makes any warranty, expressed or implied, or assumes any legal liability or responsibility for the accuracy, completeness, or usefulness, of any information, apparatus, or product or process disclosed herein or represents that its use will not infringe privately owned rights. Reference herein to any specific commercial product, process, or service by trademark, name, manufacturer or otherwise does not necessarily constitute or imply endorsement, recommendation, or favoring of same by WSRC or by the United States Government or any agency thereof. The views and opinions of the authors expressed herein do not necessarily state or reflect those of the United States Government or any agency thereof.

\author{
Printed in the United States of America \\ Prepared For \\ U.S. Department of Energy
}


Key Words: Induction Melter Offgas Sampling LaBS Frit X

Retention: Permanent

\title{
Pu Immobilization - Induction Melting and Offgas Testing
}

\author{
T.M. Jones, J.R. Zamecnik, D.H. Miller, D.T. Herman, and J.C. Marra
}

November 2006

Process Science \& Engineering Savannah River National Laboratory Aiken, SC 29808 
WSRC-TR-2006-00458

M\&O-PUD-2006-00101

Revision 0

Revision 0

\section{REVIEWS AND APPROVALS}

\section{AUTHORS:}

T.M. Jones, Process Science and Engineering Section

Date

J.R. Zamecnik, Process Science and Engineering Section

Date

D.H. Miller, Process Science and Engineering Section

Date

D.T. Herman, Chemical Science and Technology Section

Date

J.C. Marra, Materials Science and Technology Section

Date

\section{TECHNICAL REVIEWER:}

M.E. Smith, Process Science and Engineering Section

Date

\section{APPROVERS:}

R.E. Edwards, Manager, Process Science and Engineering Section

Date

D. A. Crowley, Manager, Stabilization Science Research

Date

D. P. Eisele, NMM Facilities Engineering Customer

Date 


\section{EXECUTIVE SUMMARY}

The Cylindrical Induction Melter (CIM) at the Aiken County Technology Laboratory (ACTL) has been operated by the Savannah River National Laboratory (SRNL) to support the Pu Disposition Conceptual Design (CD-0) development effort. ${ }^{1}$

The primary purpose of this report is to summarize the offgas sampling tests conducted in the CIM to capture and analyze the particulate and vapors emitted from lanthanide borosilicate (LaBS) Frit X with $\mathrm{HfO}_{2}$ as a surrogate for $\mathrm{PuO}_{2}$ and added impurities. In addition, this report describes several initial tests of the CIM for the vitrification of LaBS Frit X with $\mathrm{HfO}_{2}$. The activities required to produce Frit $\mathrm{X}$ from batch chemical oxides for subsequent milling to yield glass frit of nominally 20 micron particle size are also discussed.

The tests with impurities added showed that alkali salts such as $\mathrm{NaCl}$ and $\mathrm{KCl}$ were substantially emitted into the offgas system as the salt particulate, $\mathrm{HCl}$, or $\mathrm{Cl}_{2}$. Retention of $\mathrm{Na}$ and $\mathrm{K}$ in the glass were about 80 and $55 \%$, respectively. Chloride retention was about $35 \%$; chloride remaining in the glass was $0.29-0.37 \mathrm{wt} \%$. Based on a material balance, approximately $83 \%$ of $\mathrm{F}$ fed was retained in the glass at about $0.09 \mathrm{wt} \%$ (F could not be measured directly at this concentration). Transition metals $(\mathrm{Ni}, \mathrm{Cu}, \mathrm{Fe}, \mathrm{Mo}, \mathrm{Cr})$ were also volatilized to varying extents. A very small amount $(<0.1 \mathrm{~g})$ of nickel compounds and $\mathrm{KCl}$ were found in crystals deposited on the melter offgas line. Overall, about $58-72 \%$ of the impurities added were volatilized. Virtually all of the particulate species were collected on the nominal $0.3 \mu \mathrm{m}$ filter. The particulate evolution rate ranged from $2-8 \mathrm{~g} / \mathrm{kg} \mathrm{glass} / \mathrm{h}$. The particulate was found to be as small as $0.2 \mu \mathrm{m}$ and have an approximate median size of $0.5 \mu \mathrm{m}$. The particulate salt was also found to stick together by forming bridges between particles.

Further runs without washable salts are recommended. Measurements of particle size distribution for use in offgas system design and tests of simple impingement devices for particle collection are also recommended for tests in the near future. 


\section{TABLE OF CONTENTS}

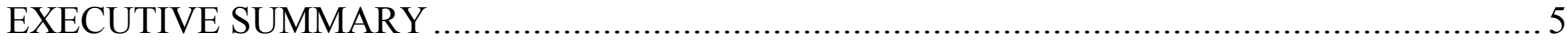

1.0 INTRODUCTION AND BACKGROUND …………

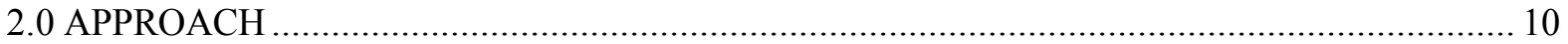

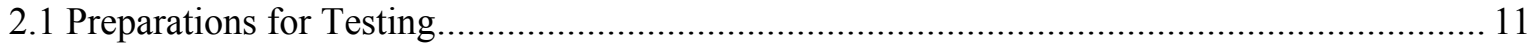

2.1.1 Chemical Procurement and Frit Fabrication ………………………………………..... 11

2.1.2 Surrogate Pu Vitrification Testing in the CIM ........................................................... 12

2.1.3 Offgas System Design, Procurement and Installation for Impurities Testing ..................... 13

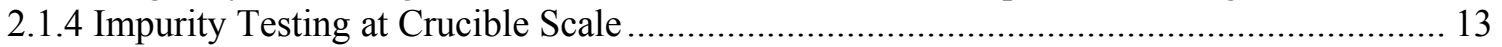

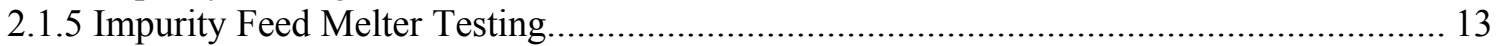

2.2 Cylindrical Induction Melter Testing Details ………....................................................... 13

2.2.1 LaBS Frit X Batch Preparation................................................................................. 13

2.2.2 Melter Process Testing - Process Batch Chemicals to Produce Frit X Cullet .................... 14

2.2.3 Melter Process Testing - Frit X with $\mathrm{HfO}_{2}$ (Molar) Substitution for $9.5 \mathrm{wt} \% \mathrm{PuO}_{2} \ldots \ldots \ldots . .16$

2.2.4 Melter Process Testing - Instrumented Canister Pour ..................................................... 17

2.2.5 Melter Process Testing - Produce Cullet Feed for Offgas Sampling Testing...................... 17

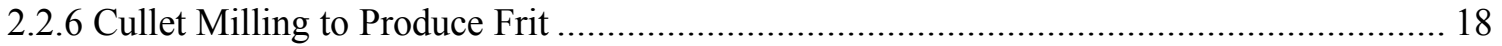

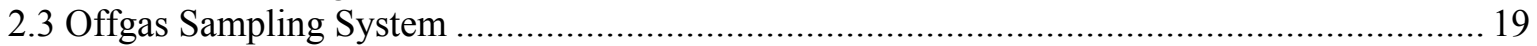

2.3.1 Offgas Sampling System Fabrication ……………………................................... 19

2.3.2 Offgas Sampling System Operation ………………….......................................... 22

2.4 Batching of Frit X, Hafnium Oxide, and Impurities.......................................................... 25

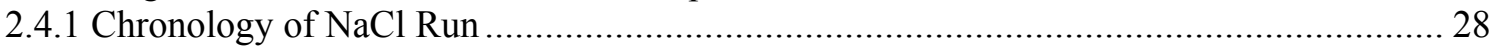

2.4.2 Chronology of Rocky Flats Run............................................................................. 29

2.4.3 Chronology Remelt Run ................................................................................. 30

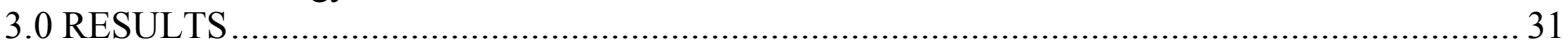

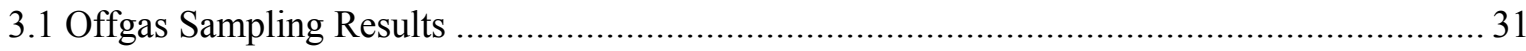

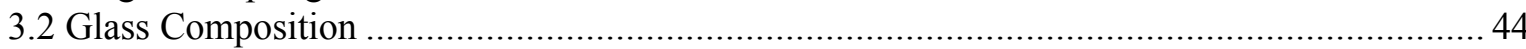

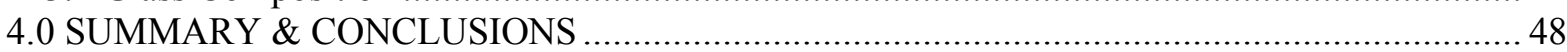

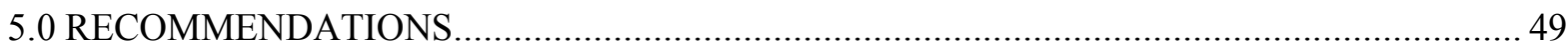

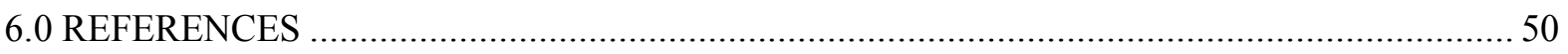

7.0 APPENDIX 


\section{LIST OF FIGURES}

Figure 1 Cylindrical Induction Melter ……................................................................... 12

Figure 2 Typical CIM Heating Profile To Process LaBS Frit X Batch Chemical ........................ 16

Figure 3 Prototype Canister Heating and Cooling Temperature Profile …................................. 17

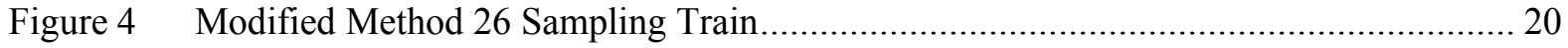

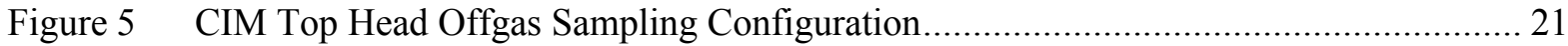

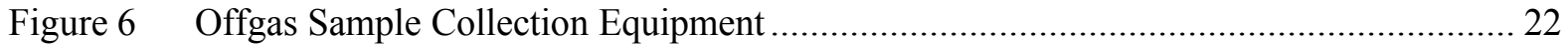

Figure 7 CIM Lexan ${ }^{\mathrm{TM}}$ Shield Barriers and Fume Hood ........................................................ 24

Figure 8 Offgas Emissions Quartz Collection Funnel and Filter .......................................... 25

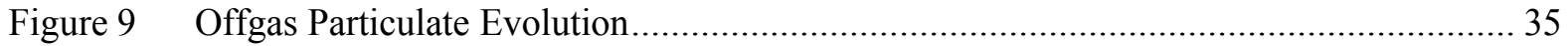

Figure 10 Particulate $\mathrm{K}, \mathrm{Na}, \mathrm{Ni}, \mathrm{Cl}$ and $\mathrm{Cl}, \mathrm{F}$ Vapor Emission Rates for the $\mathrm{NaCl}$ and Rocky

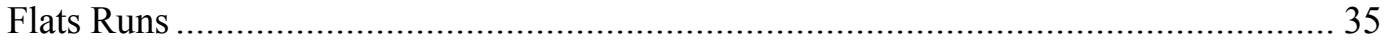

Figure 11 Particulate F, B, Mo, W, Cu and Fe Emission Rates for the Rocky Flats Run............... 36

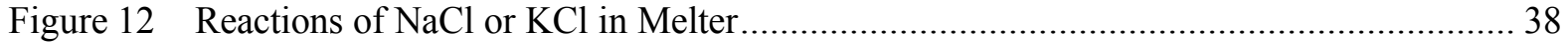

Figure 13 Photographs of Particulate on Filter from the Rocky Flats Run .................................. 39

Figure 14 SEM Photographs 1-5, 8 of Offgas Particulate from the $\mathrm{NaCl}$ Run............................... 40

Figure 15 SEM Photographs 9-11 of Offgas Particulate from the $\mathrm{NaCl}$ Run .............................. 41

Figure 16 SEM Photographs 6-7 of Offgas Particulate from the $\mathrm{NaCl}$ Run ................................ 41

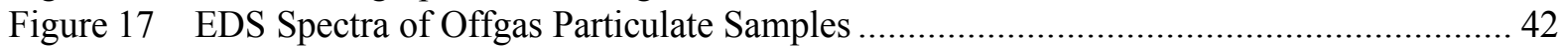

Figure 18 Offgas Line from the Rocky Flats Run Showing Crystalline Buildup and Deposits ....... 43

Figure 19 XRD Spectrum of Offgas Crystal Deposits ........................................................... 43 


\section{LIST OF TABLES}

Table $1 \quad$ Runs Performed To Process LaBS Frit X Materials ............................................... 11

Table 2 Nominal LaBS Frit X Batch Composition.............................................................. 14

Table 3 Ball Milled LaBS Frit X Sieve Analysis .................................................................... 14

Table 4 Initial Batch Quantity and Bed Height within 14-Inch Tall CIM Vessel ....................... 16

Table $5 \quad$ LaBS Frit X Cullet Yield From Batch Chemicals..................................................... 18

Table 6 Typical Particle Size Distribution from Attritor Milled LaBS Frit X Cullet ................... 19

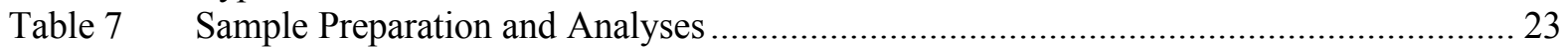

Table $8 \quad$ Feed Compositions for $\mathrm{NaCl}$ and Rocky Flats Runs................................................... 25

Table $9 \quad$ Target and Measured Composition of Frit X.............................................................. 26

Table 10 Comparison of Rocky Flats Run Feed Composition (Actual) and Documented Rocky Flats B5495 Composition (Target)........................................................... 28

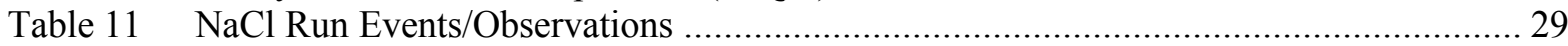

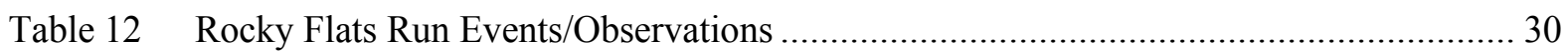

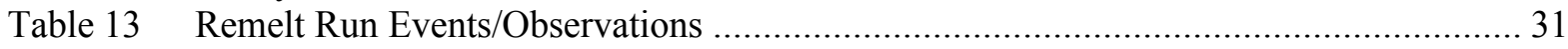

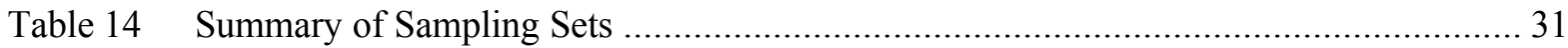

Table 15 Offgas Species Collected from the Rocky Flats Run ................................................ 32

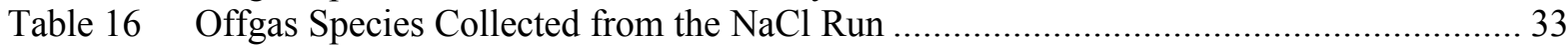

Table 17 Total and Soluble Particulate from the Rocky Flats Run ........................................... 34

Table 18 Alkali and Halides Collected in the Rocky Flats Run............................................. 37

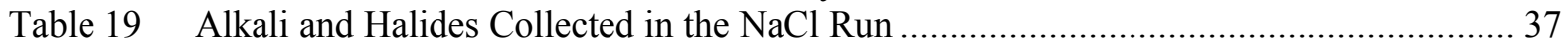

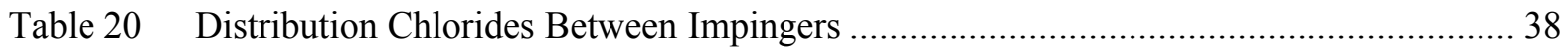

Table 21 Estimated Alkali \& Halide Content of Offgas from the Rocky Flats Run ..................... 38

Table 22 Composition of Offgas Crystals and Offgas Deposits from the Rocky Flats Run........... 44

Table 23 Predicted and Measured Compositions of Glasses Produced from Runs the $\mathrm{NaCl}$

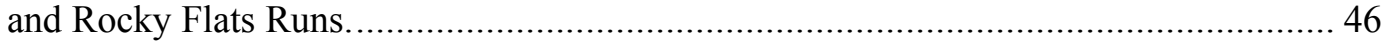

Table 24 Elemental and Oxide Concentrations Predicted and Measured for Glass from the

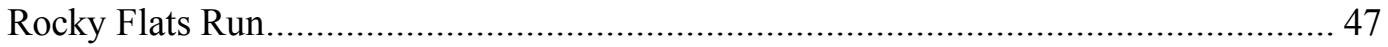

Table 25 Measured Compositions of Glass from the $\mathrm{NaCl}$ and Rocky Flats Runs...................... 48

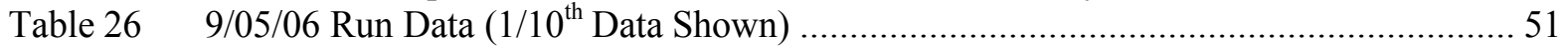




\section{LIST OF ACRONYMS}

ACTL Aiken County Technology Laboratory

$\mathrm{AD}$

Analytical Development

CIM Cylindrical Induction Melter

DF

Decontamination Factor

DOE/EM

Department of Energy Office of Environmental Management

DWPF

Defense Waste Processing Facility

EDS

Energy Dispersive X-Ray Spectroscopy

HLW

High Level Waste

IC

Ion Chromatography

ICP-AES Inductively Coupled Plasma- Atomic Emission Spectroscopy

LaBS Lanthanide Borosilicate (glass)

M\&TE Measuring \& Test Equipment

$\mathrm{Pt} / \mathrm{Rh} \quad$ Platinum/Rhodium

PDP Plutonium Disposition Project

PIP Plutonium Immobilization Project

PSAL Processing Science Analytical Laboratory

scfh standard cubic feet per hour

SEM/EDS Scanning Electron Microscopy / Energy Dispersive X-Ray Spectroscopy

SRNL Savannah River National Laboratory

SRS Savannah River Site

TTR Technical Task Request

VPWF Vitrified Plutonium Waste Form

WSRC Washington Savannah River Company 


\subsection{INTRODUCTION AND BACKGROUND}

The Department of Energy-Environmental Management (DOE-EM) plans to conduct the Plutonium Disposition Project (PDP) at the Savannah River Site (SRS). An important part of this project is to reduce the attractiveness of plutonium scrap by fabricating a durable plutonium glass form and immobilizing this $\mathrm{Pu}$ form within the high level waste (HLW) glass prepared in the Defense Waste Processing Facility (DWPF). In support of the previous Plutonium Immobilization Program (PIP), a glass formulation was developed that was capable of incorporating large amounts of actinides as well as accommodating any impurities that may be associated with $\mathrm{Pu}$ feed streams. The basis for the glass formulation was derived from commercial glasses that had high lanthanide loadings. A development effort $^{2}$ led to a Lanthanide BoroSilicate (LaBS) glass that accommodated significant quantities of actinides, tolerated impurities associated with the actinide feed streams and could be processed using established melter technologies. A Cylindrical Induction Melter (CIM) was developed during the PIP for vitrification of the $\mathrm{Pu}$ LaBS glass. The CIM system consisted of an inductively heated platinum rhodium (Pt-Rh) containment vessel (3" diameter), an induction heating system, a control system and an offgas filtering system. Following the PIP, the CIM melter was extensively studied and refined in support of the $\mathrm{Am} / \mathrm{Cm}$ vitrification development program. ${ }^{3}$

Although significant testing has been conducted on the CIM in support of Am-Cm vitrification, the application to vitrification of $\mathrm{Pu}$ has not been extensively tested. Experimental studies on the vitrification of plutonium oxide surrogates were begun to support the PDP. In these studies, $\mathrm{PuO}_{2}$ surrogate $\left(\mathrm{HfO}_{2}\right)$ feed streams, some containing various impurities, and LaBS glass frit were fed to the CIM to produce the glass product. Thorough evaluation of melter operating parameters and melter performance for this application are required. Testing of the CIM with impurities that are likely to be present in the $\mathrm{Pu}$ feeds is also required to evaluate the effect of the impurities on the glass produced, to quantify the offgases produced during the vitrification process, and to begin the process of testing offgas treatment systems.

\subsection{APPROACH}

Sixteen vitrification runs were completed in the CIM where LaBS Frit X glass was processed (See Table 1). In the initial three runs, raw batch chemicals were measured and pre-blended prior to processing in the CIM to produce LaBS Frit X glass cullet. The cullet produced in the Runs 1-3 was next milled in ball mill jars to a nominal 140 mesh size to resemble frit. For Runs 4-6, LaBS Frit X (from Runs 1-3) was processed with $\mathrm{HfO}_{2}$ added to represent $9.5 \mathrm{wt} \% \mathrm{PuO}_{2}$ on a molar basis. The LaBS Frit X cullet from Runs 4-6 was processed in Run 7 to produce glass that was poured into a prototypical stainless steel canister to measure the temperature on the outer surface of the canister as the can and glass cooled. Runs 8-13 processed raw batch chemicals to produce more LaBS Frit X cullet for future melter and offgas tests. The cullet produced by these runs $(15 \mathrm{~kg})$ was milled using an attritor mill by an outside contractor to size reduce the cullet to the desired nominal 20 micron grain sized frit. Runs 14-16 processed LaBS Frit X with chemical additions blended with the frit to simulate impurities expected to be present in the $\mathrm{PuO}_{2}$ powder to be processed by the plant. The purpose of Run 14 ( $\mathrm{NaCl}$ Run) was to sample the offgas emissions and fumes that are generated during the vitrification of the LaBS Frit X blended with NaCl. Run 15 (Rocky Flats Run) sampled the offgas emitted while vitrifying LaBS Frit X blended with simulated Rocky Flats Can B5495 impurities (see Section 2.4), and Run 16 (Remelt Run) sampled the offgas emitted as the glass produced from Run 15 was reheated to complete the evolution of volatiles. 
Table 1 Runs Performed To Process LaBS Frit X Materials

\begin{tabular}{|c|c|c|}
\hline Date & Run Title & Material Processed in CIM \\
\hline $6 / 29 / 06$ & Run 1 Process Frit X Batch To Produce Cullet & $2170 \mathrm{~g}$ Frit X Batch Chemicals \\
\hline $7 / 11 / 06$ & Run 2 Process Frit X Batch To Produce Cullet & 2193 g Frit X Batch Chemicals \\
\hline $7 / 13 / 06$ & Run 3 Process Frit X Batch To Produce Cullet & $3264 \mathrm{~g}$ Frit X Batch Chemicals \\
\hline $8 / 9 / 06$ & Run 4 Frit X With $\mathrm{HfO} 2 \mathrm{Sub}$ for $9.5 \mathrm{wt} \% \mathrm{PuO} 2$ & $1849.2 \mathrm{~g}$ Frit $\mathrm{X}(140 \mathrm{mesh})$ with $150.8 \mathrm{~g} \mathrm{HfO} 2$ blended in \\
\hline $8 / 1606$ & Run 5 Frit X With $\mathrm{HfO} 2 \mathrm{Sub}$ for $9.5 \mathrm{wt} \% \mathrm{PuO} 2$ & $1849.2 \mathrm{~g}$ Frit $\mathrm{X}(140 \mathrm{mesh})$ with $150.8 \mathrm{~g} \mathrm{HfO} 2$ blended in \\
\hline $8 / 17 / 06$ & Run 6 Frit X With HfO2 Sub for 9.5 wt $\% \mathrm{PuO} 2$ & 1849.2 g Frit X (140 mesh) with $150.8 \mathrm{~g} \mathrm{HfO} 2$ blended in \\
\hline $8 / 24 / 06$ & Run 7 Fill Canister With LaBS Frit X Glass & $6020 \mathrm{~g}$ LaBS Frit $X$ cullet from Runs 4, 5 and 6 \\
\hline $9 / 5 / 06$ & Run 8 Process Frit X Batch To Produce Cullet & $3000 \mathrm{~g}$ Frit X Batch Chemicals \\
\hline $9 / 6 / 06$ & Run 9 Process Frit X Batch To Produce Cullet & $3100 \mathrm{~g}$ Frit X Batch Chemicals \\
\hline 9/7/06 & Run 10 Process Frit X Batch To Produce Cullet & $2600 \mathrm{~g}$ Frit X Batch Chemicals \\
\hline $9 / 13 / 06$ & Run 11 Process Frit X Batch To Produce Cullet & $2600 \mathrm{~g}$ Frit X Batch Chemicals \\
\hline $9 / 18 / 06$ & Run 12 Process Frit X Batch To Produce Cullet & $3189 \mathrm{~g}$ Frit X Batch Chemicals \\
\hline $9 / 20 / 06$ & Run 13 Process Frit X Batch To Produce Cullet & $3191 \mathrm{~g}$ Frit X Batch Chemicals \\
\hline $10 / 11 / 06$ & $\begin{array}{l}\text { Run } 14 \text { Process Frit X with } \mathrm{NaCl} \text { Impurity Addition } \\
\text { aka "NaCl Run" or "Run 101006" }\end{array}$ & 3000 g Frit X / HfO2 / NaCl blend \\
\hline $10 / 26 / 06$ & $\begin{array}{l}\text { Run } 15 \text { Process Frit X with Rocky Flats B5495 Addition } \\
\text { aka "Rocky Flats Run" or "Run 102606") }\end{array}$ & $\begin{array}{l}2981 \text { g Frit X / HfO2 / Rocky Flats Can B5495 surrogate } \\
\text { blend }\end{array}$ \\
\hline $11 / 1 / 06$ & $\begin{array}{l}\text { Run } 16 \text { Reprocess Run } 15 \text { Cullet Product } \\
\text { aka "Remelt Run" or "Run 110106" }\end{array}$ & $2833 \mathrm{~g}$ glass from Run 15 \\
\hline
\end{tabular}

\subsection{Preparations for Testing}

A number of preparations were required to be completed before initiation of LaBS glass melter testing. These activities included: procurement of chemicals, batching of LaBS frit, fabrication of LaBS frit, and readying the CIM for testing.

\subsubsection{Chemical Procurement and Frit Fabrication}

An inventory of available chemicals was made and chemicals were ordered. It should be noted that hafnium oxide $\left(\mathrm{HfO}_{2}\right)$ was used as a surrogate for plutonium oxide $\left(\mathrm{PuO}_{2}\right)$. As is standard practice when substituting for a radioactive element in glass, the hafnium was substituted for the plutonium on a equimolar basis. Therefore, the weight percent of $\mathrm{HfO}_{2}$ in the glass will not equal the weight percent of $\mathrm{PuO}_{2}$ in a comparable radioactive glass.

Batch sheets were prepared to specify the chemicals and quantities needed to prepare the frit batch. The chemicals were batched in accordance with these batch sheets. The batch sheets were posted in the laboratory notebooks WSRC-NB-2001-00086 ${ }^{4}$ and WSRC-NB-2006-00144 ${ }^{5}$.

The glass frit was fabricated using the CIM. The batch chemicals were added into the CIM and melted. The discharged glass was "fritted" by pouring it from the melter into water. The resulting glass cullet was dried before sizing for final simulant $\mathrm{Pu}$ batch preparation. The composition of the fabricated cullet was verified via chemical analysis in the SRNL Mobile Lab before use in subsequent melter testing. The cullet was initially size reduced using a ball mill to provide nominally -140 mesh (-106 micron) sized frit feed for the melter. Subsequent cullet produced in the CIM to support offgas impurities tests was milled by an outside vendor utilizing an attritor mill to attain 20 micron sized frit. 


\subsubsection{Surrogate Pu Vitrification Testing in the CIM}

The CIM was prepared to support the LaBS glass pour testing. A photo of the CIM at ACTL is shown in Figure 1. For the CIM to be in proper working order, the calibration of process thermocouples had to be performed to ensure that the melting process is prototypical. The CIM also had to be capable of maintaining the glass melt at a temperature of $1500^{\circ} \mathrm{C}$ for 4 hours, then draining the glass product into an appropriate receipt container.

In advance of design and installation of an offgas filtering system, melter testing was conducted in the CIM using an existing fume hood configuration and glass compositions that contained no impurities (i.e. no hazardous species). These tests provided initial data regarding melter operating performance and throughput. Melter feed was batched using LaBS Frit X and $\mathrm{HfO}_{2}$ as a surrogate for $\mathrm{PuO}_{2}$ on an equivalent molar basis. Specific objectives of these tests included evaluation of dry feed (powder) melting behavior, melter operation parameters (power input and temperature), melter pouring behavior, melter cycle time, melter structural behavior, and glass quality produced by the test runs.

Batch sheets were prepared to specify the quantities of frit, hafnium oxide and other additives to be blended to produce the glass batch. The Frit $\mathrm{X}$ and $\mathrm{HfO}_{2}$ were batched in accordance with these batch sheets, which were affixed into the laboratory notebooks, WSRC-NB-2001-00086 and WSRC-NB2006-00144.

Individual run plans were developed for each melter campaign. The run plans specify the specific objectives for each campaign and identify specific test criteria to measure during the test campaign. The run plans and data associated with the campaign are included in the laboratory notebooks, WSRC-NB-2001-00086 and WSRC-NB-2006-00144.

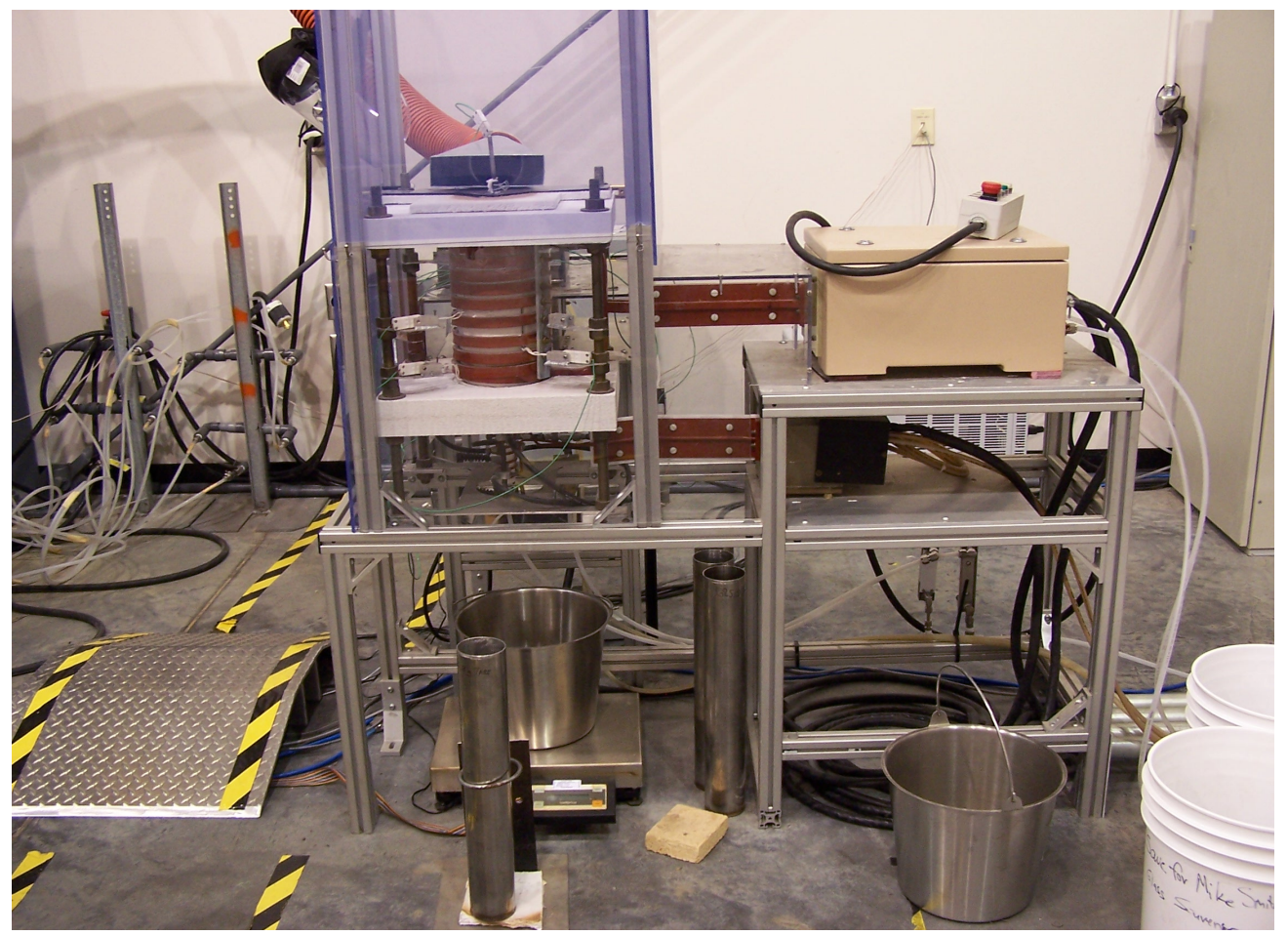

Figure 1 Cylindrical Induction Melter 


\subsubsection{Offgas System Design, Procurement and Installation for Impurities Testing}

Some form an of offgas system will be required for operating the $\mathrm{CIM}$ with $\mathrm{Pu}$ in a glovebox environment. The specific requirements of the offgas system are not known at this time. This subtask evaluated likely requirements for the offgas system in order to provide information to support the design of a suitable offgas system. An offgas sampling system was coupled with the CIM for testing with impurity compositions.

Offgas systems had been previously designed for the CIM for applications in the PIP and Am/Cm vitrification efforts. The system designed for PIP was never fabricated or tested. The PIP offgas system design will be evaluated for applicability to facilitate design for the current application. The requirements for the $\mathrm{Am} / \mathrm{Cm}$ system were different because the $\mathrm{Am} / \mathrm{Cm}$ flowsheet utilized a liquid feed to the melter. However, the design for the $\mathrm{Am} / \mathrm{Cm}$ vitrification system may also provide insight into design aspects for the current dry-feed application.

\subsubsection{Impurity Testing at Crucible Scale}

Impurity testing was conducted at the crucible and smaller scale to provide a basis for the melter scale testing. This work examined the effects of several likely impurities on the glass produced and also estimated the volatility of the impurity species by thermogravimetric analysis. The results of these tests have been documented in a separate report. ${ }^{6}$

\subsubsection{Impurity Feed Melter Testing}

The melter coupled with the offgas sampling system was utilized for impurity feed testing to demonstrate processing of the impurity feed compositions and identify any challenges associated with specific feeds by analysis of the particulate and fume samples collected. Due to the time requirements associated with this task, only very limited impurity feed testing was completed in this initial phase of testing. It is anticipated that extensive follow-on testing will be conducted in a future task.

Melter feed was batched using LaBS Frit X frit, $\mathrm{HfO}_{2}$ as a surrogate for $\mathrm{PuO}_{2}$ on an equivalent molar basis, and impurity components anticipated for the various feed streams. Specific objectives of this testing included evaluation of: melter operation parameters, offgas behavior, melter structural behavior, and glass quality produced from the impurity feeds tested.

Batch sheets were prepared to specify the quantities of frit, hafnium oxide and impurities needed to prepare the glass batch. The frit, $\mathrm{HfO}_{2}$ and impurities were batched in accordance with these batch sheets, and the batch sheets were included in the laboratory notebooks.

A run plan was developed for each melter campaign that specified objectives for the campaign and identified test criteria to measure during the test campaign. The run plans and data associated with the campaign were included in the laboratory notebooks.

\subsection{Cylindrical Induction Melter Testing Details}

\subsubsection{LaBS Frit X Batch Preparation}

\subsubsection{Batch Chemicals Preparation and Processing}

The basic LaBS Frit $\mathrm{X}$ batch used for the CIM runs was produced from raw batch chemical oxides. The nominal LaBS Frit X batch composition is shown in Table 2. After each constituent 
was weighed to comprise a nominal $2 \mathrm{~kg}$ final glass product, the total quantity of materials was blended together in a ball mill to achieve intimate mixing. The blended batch was then heated to $1400^{\circ} \mathrm{C}$ in the CIM, where it was homogenized for three hours by air bubbling prior to draining into water to yield cullet.

\section{Table 2 Nominal LaBS Frit X Batch Composition}

\begin{tabular}{|cc|}
\hline \multicolumn{1}{|c|}{ Oxide } & Mass \% \\
\hline $\mathrm{Al}_{2} \mathrm{O}_{3}$ & 10.00 \\
\hline $\mathrm{B}_{2} \mathrm{O}_{3}$ & 13.00 \\
\hline $\mathrm{Gd}_{2} \mathrm{O}_{3}$ & 13.50 \\
\hline $\mathrm{HfO}_{2}$ & 7.00 \\
\hline $\mathrm{La}_{2} \mathrm{O}_{3}$ & 19.00 \\
\hline $\mathrm{Nd}_{2} \mathrm{O}_{3}$ & 15.00 \\
\hline $\mathrm{SiO}_{2}$ & 20.00 \\
\hline $\mathrm{SrO}$ & 2.50 \\
\hline
\end{tabular}

\subsubsection{Cullet Size Reduction}

The cullet produced by Runs 1-3 was ball milled to a nominal 140 mesh size. 500 g quantities of cullet were ball milled for 2 hours, then sieved with a 30 mesh screen. The material that passed through the 30 mesh screen was bagged as feed stock for the melter. The material larger than 30 mesh was returned to the ball mill with additional un-milled cullet to make up the balance of 500 $\mathrm{g}$, and milled for 2 hours. This process was repeated until all of the available cullet was milled sufficiently to pass through the 30 mesh sieve. The particle size distribution of a sample of the milled material is shown in Table 3.

\section{Table 3 Ball Milled LaBS Frit X Sieve Analysis}

\begin{tabular}{|cc|}
$\begin{array}{c}\text { Sieve Size } \\
\text { Mesh }\end{array}$ & \% Retained \\
\hline 50 & 9.29 \\
\hline 140 & 51.23 \\
\hline 200 & 19.46 \\
\hline 325 & 15.42 \\
\hline 400 & 2.58 \\
\hline 635 & 1.31 \\
\hline Total & $\mathbf{9 9 . 2 9}$ \\
\hline
\end{tabular}

\subsubsection{Melter Process Testing - Process Batch Chemicals to Produce Frit X Cullet}

Nominally 2 to $3 \mathrm{~kg}$ of batch chemical oxides were charged to the empty CIM melter vessel. A 2000 $\mathrm{g}$ charge of batch chemicals resulted in a batch bed height of 7 inches inside the 14 inch tall CIM vessel, and $3 \mathrm{~kg}$ of batch chemicals measured 10 inches. (The batch materials and bed heights for the CIM tests are shown in Table 4.) Then, the vessel cylinder and conical bottom induction heaters were energized at the minimum induction power $(0 / 4095)$ for 30 minutes to ensure that any moisture present within the batch was driven off. (Note: 0/4095 indicates the controller output used. The output can be set to any integer value from 0 to 4095.) 
Additional heating time at minimum induction power input was required when more than $2 \mathrm{~kg}$ of batch chemicals were being processed in the CIM to allow chemically bound water (from the boric acid in the batch) to be driven from the batch bed. Heating larger charges of batch too quickly may cause a significant batch bed expansion as the chemically bound water diffuses through the powders to escape. When a bed expansion occurs, the mass of batch chemicals rises up within the CIM vessel. Continued bed expansion could eventually contact the top insulation cover and in severe cases could spill over onto the top of the CIM upper insulation block.

The emission of the moisture from the batch bed entrained a small amount of batch powder as it vented from the top of the CIM vessel and into the offgas air sweep. This emission of batch solids was not as evident when frit was being processed, probably because the boric acid in the raw batch chemicals oxides had already released the chemically bound water during the first vitrification evolution to make the cullet used to produce the frit.

The induction heating power to the cylinder and cone bottom induction heating coils was then ramped at $10 / 4095$ increments per minute (about $0.25 \% / \mathrm{min}$ output) to achieve a nominal temperature increase of 5 to $10^{\circ} \mathrm{C}$ per minute at the $\mathrm{Pt} / \mathrm{Rh}$ vessel control thermocouple (T4). A batch bed thermocouple (T1), located along the centerline and 1 inch above the bottom of the CIM vessel, was used to monitor the temperature within the batch bed and eventually provided an indication of the molten glass pool temperature. When the glass pool temperature reached $1380^{\circ} \mathrm{C}$, air bubbling through the glass was initiated at $0.75 \mathrm{scfh}$ air flow rate to facilitate mixing. The glass was held at $1400^{\circ} \mathrm{C}$ or greater for 3 hours. Glass pouring was initiated by applying heat to the CIM drain tube. The melter contents were typically discharged into a water-filled stainless steel pail, yielding glass cullet.

The total time required from beginning melter heating to initiation of glass pouring was typically 6 hours 30 minutes. The CIM cool down was achieved by ramping the induction heating power at about 50/4095 increments per minute down to minimum power, then de-energizing the power supplies. The cooling water flow through the induction heating coils was maintained until the indicated vessel temperature was less than $100^{\circ} \mathrm{C}$, at which time the cooling water flow was terminated. The CIM typically cooled to less than $100^{\circ} \mathrm{C}$ within two hours of initiation of the cooling evolution (completion of glass draining). The typical CIM heating profile to process LaBS Frit $\mathrm{X}$ batch chemicals is shown in Figure 2. The CIM temperature and power input data for this run are shown in Table 26 in the Appendix. 
Table 4 Initial Batch Quantity and Bed Height within 14-Inch Tall CIM Vessel

\begin{tabular}{|cccc|}
\hline Run & $\begin{array}{c}\text { Material } \\
\text { Added (g) }\end{array}$ & $\begin{array}{c}\text { Initial Batch } \\
\text { Bed Height } \\
\text { (in) }\end{array}$ & Material Batched \\
\hline 1 & 2170 & 7 & Batch Chemicals \\
\hline 2 & 2193 & 7.75 & Batch Chemicals \\
\hline 3 & 3264 & 11.25 & Batch Chemicals \\
\hline 4 & 2000 & 5 & 140 mesh Frit \\
\hline 5 & 2000 & 5 & 140 mesh Frit \\
\hline 6 & 2039 & 5 & 140 mesh Frit \\
\hline 7 & 6020 & 9.5 & Glass Cullet \\
\hline 8 & 3000 & 10 & Batch Chemicals \\
\hline 9 & 3100 & 10 & Batch Chemicals \\
\hline 10 & 2600 & 8.5 & Batch Chemicals \\
\hline 11 & 2600 & 8.5 & Batch Chemicals \\
\hline 12 & 3189 & 10.25 & Batch Chemicals \\
\hline 13 & 3191 & 10.5 & Batch Chemicals \\
\hline 14 & 3000 & 8.5 & Frit X / HfO $/$ NaCl \\
\hline 15 & 2981 & 8 & Frit X $/$ HfO $/$ Impurities \\
\hline 16 & 2833 & 5.75 & Glass Cullet from Run 16 \\
\hline
\end{tabular}

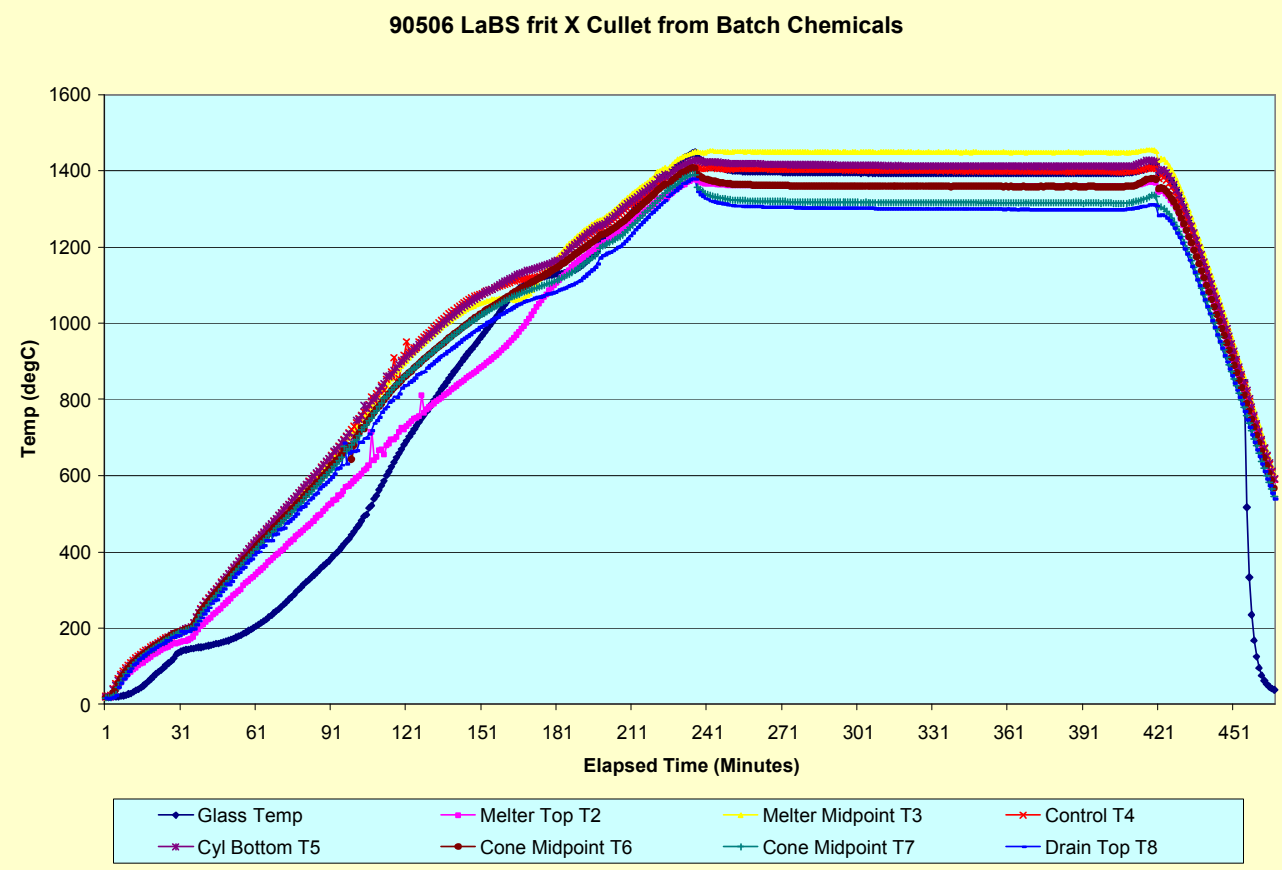

Figure 2 Typical CIM Heating Profile To Process LaBS Frit X Batch Chemical

\subsubsection{Melter Process Testing - Frit $\mathrm{X}$ with $\mathrm{HfO}_{2}$ (Molar) Substitution for $9.5 \mathrm{wt} \% \mathrm{PuO}_{2}$}

In Runs 4-6, an 1850 gram charge of LaBS Frit X from cullet previously milled to a nominal 140 mesh particle size $\left(<100\right.$ microns) was combined with $150 \mathrm{~g}$ of $\mathrm{HfO}_{2}$ powder in a $\mathrm{Braun}^{\mathrm{TM}}$ mixer to yield LaBS glass where $\mathrm{HfO}_{2}$ was substituted for $9.5 \mathrm{wt} \%$ (molar basis) $\mathrm{PuO}_{2}$. The nominal 2000 gram charge was added into the CIM at ambient temperature, and the batch bed height was measured to be 5-inches (total height of the melter vessel is 14-inches). The material was subjected to a 
standard heating schedule for CIM processing of LaBS frit, including 30 minutes initial heating at minimum induction heating power input, followed by a 5 to $10^{\circ} \mathrm{C}$ per minute temperature increase to $1400^{\circ} \mathrm{C}$, and finally 3 hours mixing with an air bubbler while at $1400^{\circ} \mathrm{C}$. The vitrified glass product was discharged into a pail of water, allowed to cool, and then dried. Nominally, $2000 \mathrm{~g}$ of glass was produced in each run.

\subsubsection{Melter Process Testing - Instrumented Canister Pour}

Run 7 was performed to vitrify $6 \mathrm{~kg}$ of LaBS Frit X cullet for the purpose of pouring into a stainless steel canister and measuring the heat emitted by the canister. A $19.5^{\prime \prime}$ by $3^{\prime \prime}$ OD canister $\left(1 / 16^{\prime \prime}\right.$ wall thickness) was instrumented with three type-R thermocouples contacting the outer can wall at the 4", 9" and 13" elevations. $6020 \mathrm{~g}$ of LaBS Frit X cullet (produced from raw batch chemicals in Runs 4-6, with additional $\mathrm{HfO}_{2}$ added to represent $9.5 \mathrm{wt} \% \mathrm{PuO}_{2}$ on a molar basis) was charged into the CIM, resulting in a 9.5" bed height (of 14" total in CIM vessel). The cullet was heated to $1400^{\circ} \mathrm{C}$ in 3 hours 50 minutes and then air bubbling was initiated at $0.75 \mathrm{scfh}$ to homogenize the glass for an additional 2 hours at $1400^{\circ} \mathrm{C}$. Induction heating power was then applied to the drain tube induction heater, and glass pouring was established after a short period (less than 1 minute) of initial glass dripping. The pour stream of 17 minutes duration filled the canister with $13.75^{\prime \prime}$ of glass $(5991.7 \mathrm{~g})$. The peak temperature indicated by the $4 "$ elevation canister thermocouple was $594^{\circ} \mathrm{C}$, and the 9 " elevation thermocouple peaked at $626^{\circ} \mathrm{C}$. The $13^{\prime \prime}$ elevation thermocouple peaked at $440^{\circ} \mathrm{C}$ due to the limited quantity of glass poured only filling the canister to $13.5^{\prime \prime}$ elevation. The goal for completely filling a canister is to pour glass to a 17.5 " elevation, or 2 " from the top of the canister. The can temperatures as the canister cooled were recorded by computer and are shown in Figure 3.

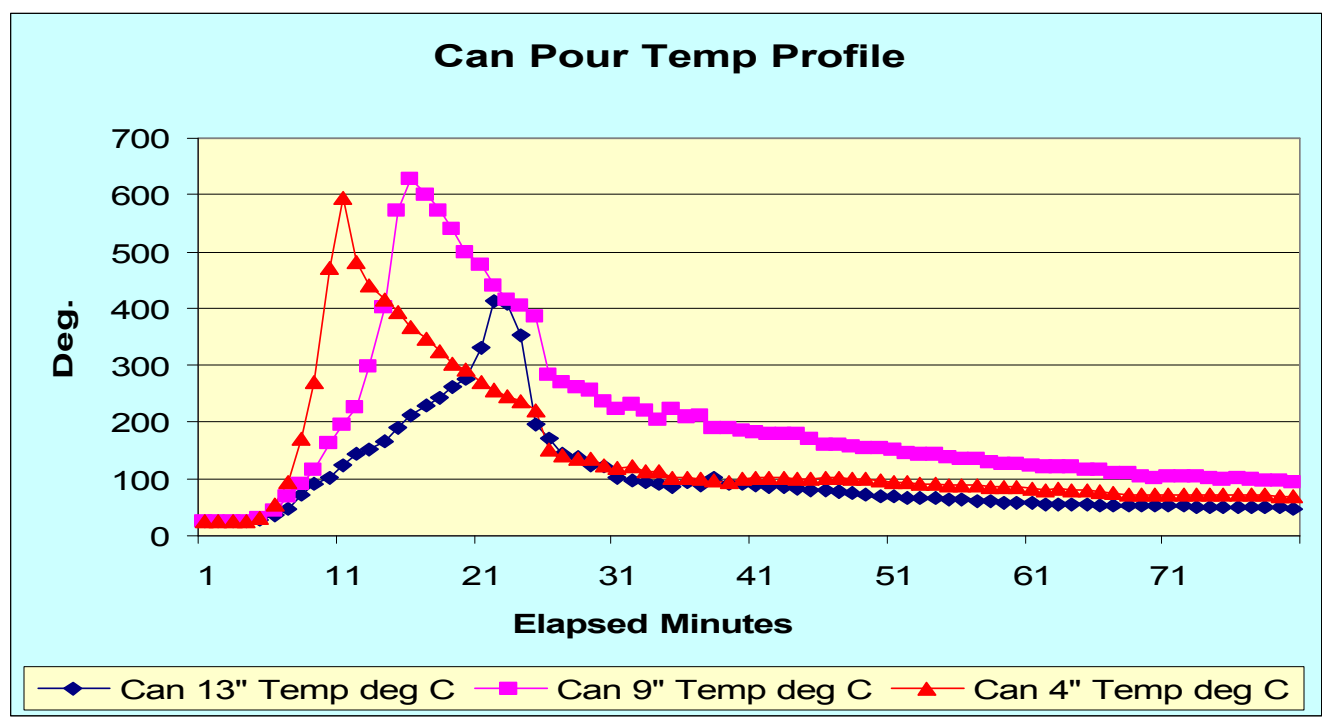

Figure 3 Prototype Canister Heating and Cooling Temperature Profile

\subsubsection{Melter Process Testing - Produce Cullet Feed for Offgas Sampling Testing}

As with Runs 1-3, Runs 8-13 were performed to produce cullet from LaBS Frit X batch chemicals that was milled to nominally 20 microns particle size frit. The resultant frit was used as feed for offgas impurities testing (Runs 14-16). Nominally 2600 to $3200 \mathrm{~g}$ of LaBS Frit X blended/ball milled batch chemical oxides were charged to the empty CIM melter vessel. The yields of these batches are given in Table 5. Again, it should be noted that the use of boric acid as the source of boron for the glass resulted in weight loss during the melting process. (The batch bed heights for the CIM tests are 
shown in Table 4.) Then, the vessel cylinder and conical bottom induction heaters were energized at an initial power input of 0/4095 (minimum induction power) for 30 minutes to ensure any moisture present within the batch is driven off. After the initial heating at minimum induction heating power input, the vessel and cone bottom induction heating power inputs were set to 350/4095 and power ramping initiated at a rate increase of $10 / 4095 /$ minute for both zones. The $\mathrm{Pt} / \mathrm{Rh}$ vessel was heated at a rate of 5 to $10^{\circ} \mathrm{C}$ per minute to $1380^{\circ} \mathrm{C}$. For each run, the glass pool temperature reached the targeted $1380^{\circ} \mathrm{C}$ temperature at the vessel induction heating power input of 2200/4095 (216 volts, 32 amps, $6.91 \mathrm{~kW}$ ) and the cone bottom induction heating power input of 2100/4095 (185 volts, 12 amps, $2.22 \mathrm{~kW}$ ). A Pt/Rh bubbler tube was inserted into the glass pool to a depth of one inch above the bottom of the CIM vessel, and air bubbling was initiated at $0.75 \mathrm{scfh}$ for three hours. Upon initiation of air bubbling, the glass pool temperature very quickly reached isothermal conditions throughout the volume of glass, with the pool thermocouple (T1) indicating $1400^{\circ} \mathrm{C}$. The glass pool temperature gradually increased to $1450^{\circ} \mathrm{C}$ at the constant induction heating power inputs.

At the completion of three hours at $1400^{\circ} \mathrm{C}-1450^{\circ} \mathrm{C}$ with air bubbling, the induction heating power to the drain tube was set to $1000 / 4095(130$ volts, 4 amps, $0.6 \mathrm{~kW})$. Then the drain tube induction heating power was ramped at 50/4095/minute to a target of 1850/4095. Cooling air was applied to the lower drain tube at 50 SCFM to prevent the glass from draining until the upper section of the drain tube was sufficiently heated to assure a clean pouring initiation. When the drain tube induction heating power input reached 1850/4095 (172 volts), the drain cooling air was turned off and glass pouring began quickly thereafter (less than 30 seconds later). The contents of the vessel were poured into stainless steel pails of water to produce cullet. The drain tube was cooled by the application of the drain cooling air to freeze the last of the glass pour to provide a glass plug inside the drain tube for the next CIM run.

At the conclusion of the draining evolution, the drain tube induction heating power was immediately set to OFF. The vessel and cone bottom induction heating power inputs were ramped to 0/4095 at a rate of 50/4095/minute. Once 0/4095 induction heating power input was reached, both power supplies were set to OFF. The cooling water supply to the vessel, cone bottom and drain induction heating coils was maintained until all thermocouples indicated $200^{\circ} \mathrm{C}$ or less. The bubbler assembly and melt pool thermocouple (T1) were extracted from the vessel during the cooling cycle to prevent either from adhering to the interior vessel wall should they have contacted the vessel wall with glass residue present.

Table 5 LaBS Frit X Cullet Yield From Batch Chemicals

\begin{tabular}{|cccc|} 
Run \# & $\begin{array}{c}\text { Batch Chemicals } \\
\text { Processed } \\
(\mathbf{g})\end{array}$ & $\begin{array}{c}\text { Cullet Yield } \\
(\mathbf{g})\end{array}$ & $\begin{array}{c}\text { \% Yield By } \\
\text { Mass }\end{array}$ \\
\hline 8 & 3000 & 2673 & 89.1 \\
\hline 9 & 3100 & 2757 & 88.9 \\
\hline 10 & 2600 & 2326 & 89.4 \\
\hline 11 & 2600 & 2288 & 88.0 \\
\hline 12 & 3189 & 2803 & 87.9 \\
\hline 13 & 3191 & 2791 & 87.5 \\
\hline
\end{tabular}

\subsubsection{Cullet Milling to Produce Frit}

The cullet produced by Runs 8-13 was shipped to Union Process Inc. to be size reduced using an attritor mill. The attritor mill is the preferred technology for mixing and milling for the PDP program. The cullet was divided into batches ranging from 500 to $2000 \mathrm{~g}$ for processing in the attritor mill. A 
model SG-1 attritor mill with tungsten-carbide arms and an alumina bucket liner was used. The grinding media was $3 / 8$ " alumina. The majority of the cullet was fed to the mill after screening through an 8 mesh sieve. The mill was run for approximately 6 minutes and then discharged. The resulting product was screened with a 100 mesh sieve, with the +100 material recycled back into the mill for further size reduction. An example of the typical particle size distribution is shown in Table 6 .

Table 6 Typical Particle Size Distribution from Attritor Milled LaBS Frit X Cullet

\begin{tabular}{|cc|}
$\begin{array}{c}\text { \% Less Than } \\
\text { Indicated Size }\end{array}$ & $\begin{array}{c}\text { Particle Size } \\
\text { (micron) }\end{array}$ \\
\hline 10 & 3.454 \\
\hline 20 & 7.508 \\
\hline 30 & 11.82 \\
\hline 40 & 16.78 \\
\hline 50 & 22.63 \\
\hline 60 & 29.60 \\
\hline 70 & 38.32 \\
\hline 80 & 50.51 \\
\hline 90 & 74.16 \\
\hline 95 & 105.9 \\
\hline
\end{tabular}

The powder from the individual attritor mill batches was blended together. Additional data from the individual attritor mill batches can be found in the trip report from Union Process. ${ }^{7}$

\subsection{Offgas Sampling System}

\subsubsection{Offgas Sampling System Fabrication}

Runs 14-16 (NaCl, Rocky Flats, Remelt Runs) were conducted to sample the offgas emissions that evolve during the vitrification of LaBS Frit X blended with $\mathrm{HfO}_{2}$ (as a surrogate for $\mathrm{PuO}_{2}$ ) and expected impurities. Modifications were made to the CIM to accommodate an EPA gas sampling train. Offgas sampling was performed using a modification of EPA Source Sampling Method 26. This EPA method is applicable for determining emissions of hydrogen halides ( $\mathrm{HX})[\mathrm{HCl}, \mathrm{HBr}$, and $\mathrm{HF}]$ and halogens $\left(\mathrm{X}_{2}\right)\left[\mathrm{Cl}_{2}\right.$ and $\left.\mathrm{Br}_{2}\right]$. Bromine was not present in these tests. A diagram of the offgas sampling system is shown in Figure 4.

The top of the melter was replaced with a $3 / 8$ " thick quartz plate with a 1 " offgas vent hole and two smaller penetrations to accommodate the glass melt thermocouple and the bubbler (see Figure 5). A 1 " thick sheet of M-board insulation was placed on top of the quartz plate. A quartz cylinder was placed into the hole in M-board and quartz plate so that the offgases leaving the melter would not contact the M-board insulation. The offgases were collected by a Pyrex ${ }^{\mathrm{TM}}$ glass sampling funnel that was positioned above the melter vent penetration, and the balance of the glasswork and impinger vessels were positioned in close proximity to the melter by the addition of a new support platform (see Figure 6). 


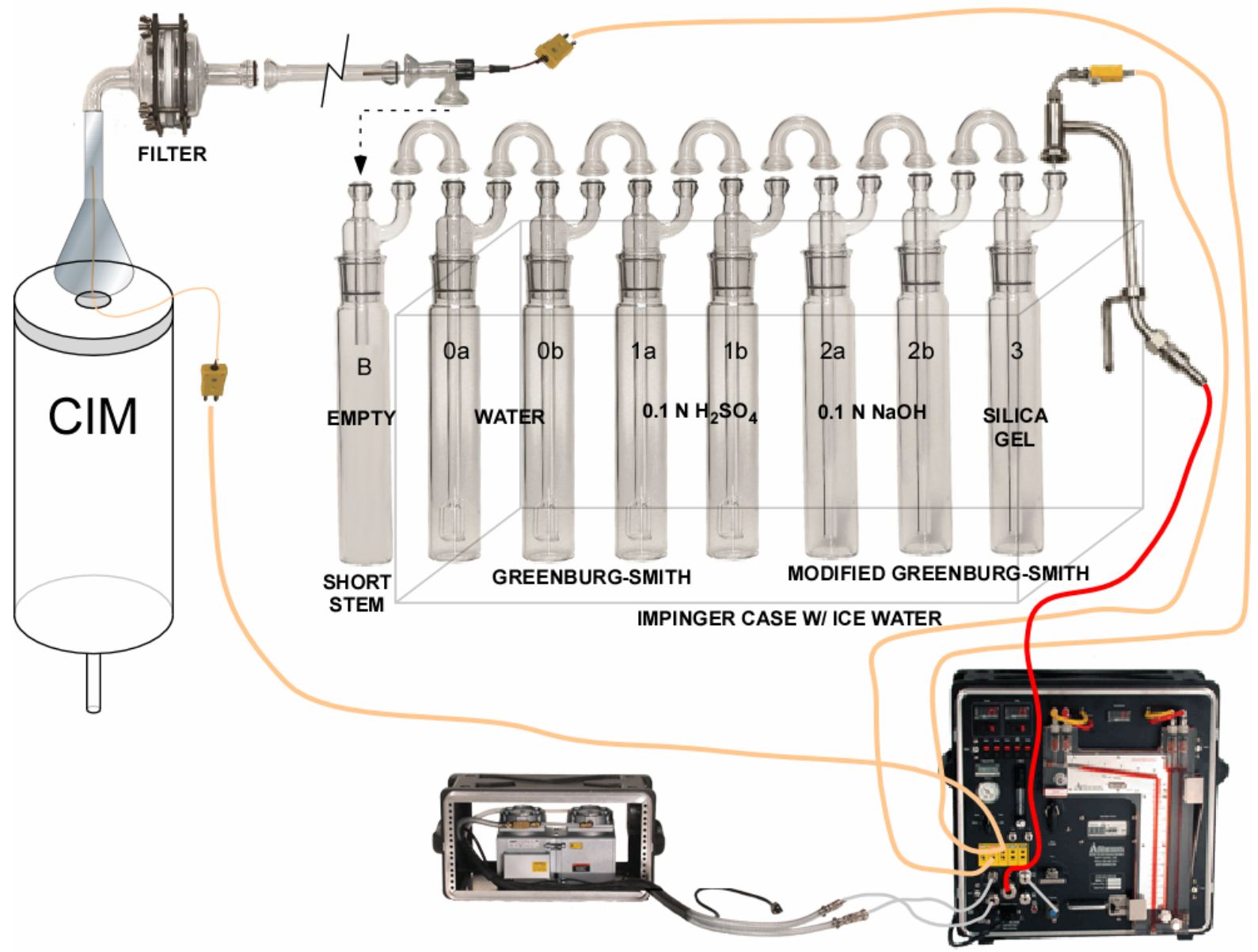

Figure 4 Modified Method 26 Sampling Train 


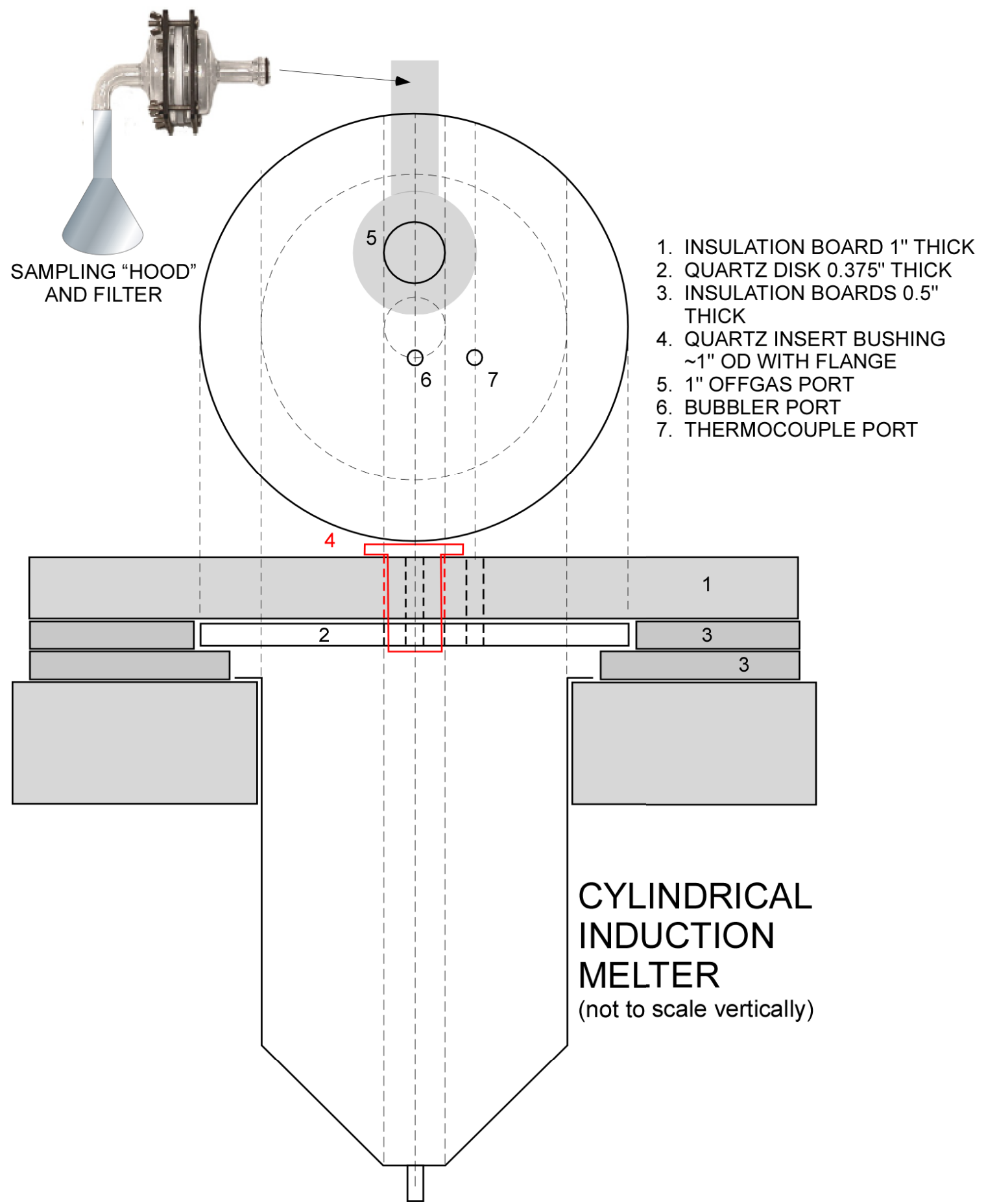

Figure 5 CIM Top Head Offgas Sampling Configuration 


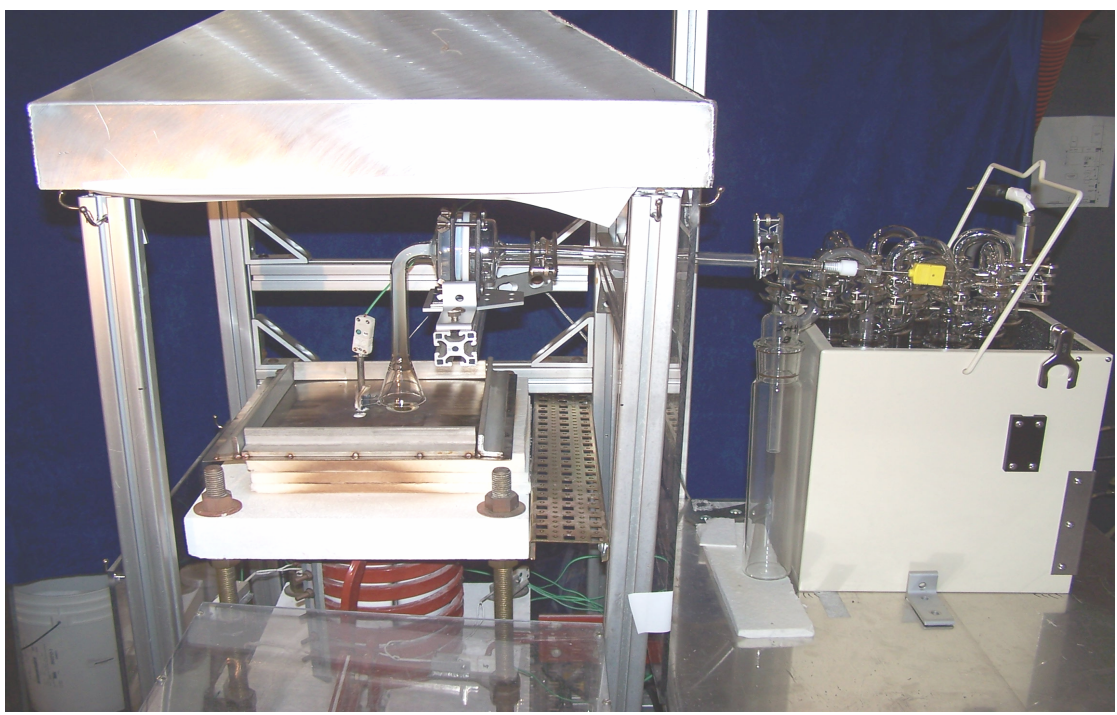

\section{Figure 6 Offgas Sample Collection Equipment}

A 3" diameter quartz fiber on Teflon ${ }^{\mathrm{TM}}$ mesh filter was used to collect particulate. The filter papers have $99.95 \%$ efficiency for dioctyl phthalate (DOP) particles at $0.3 \mu \mathrm{m}$. The offgas was then passed through an empty impinger, two water impingers, two $0.1 \mathrm{~N}(0.05 \mathrm{M})$ sulfuric acid $\left(\mathrm{H}_{2} \mathrm{SO}_{4}\right)$ impingers, two $0.1 \mathrm{~N}$ sodium hydroxide $(\mathrm{NaOH})$ impingers, and then a silica gel impinger to remove any water vapor remaining in the gas. All except the empty impinger were kept at near $0{ }^{\circ} \mathrm{C}$ in an ice bath. The gas flowrate varied from around 0.15 to $0.6 \mathrm{ft}^{3} / \mathrm{min}(\mathrm{cfm})$. The flowrate was measured with an orifice meter and a dry gas meter.

\subsubsection{Offgas Sampling System Operation}

Because the stack sampling system collected the entire offgas from the melter, isokinetic sampling was not required, so control of the sampling rate was not critical so long as all of the offgas was collected. During filter and impinger changes, there were short ( $<5$ minutes) periods where the offgas was not collected.

The particulate matter recovered from the filter and filter inlet were analyzed for halides, other anions, metals, and by SEM/EDS. This analysis is not part of EPA Method 26; these methods quantify only the hydrogen halides and halogens. There is no EPA method for halide salts. The total particulate mass was also measured approximately by weighing filter assembly before and after sampling.

The first empty impinger was used to protect the melter from accidental flow reversal in the sample system that could have resulted in water being sprayed onto the top of the melter. The empty impinger and the outlet of the filter were rinsed with water and analyzed with the water impinger contents.

The water impingers were added to the EPA method to help distinguish between chloride from $\mathrm{HCl}$ vapor and from $\mathrm{NaCl}, \mathrm{KCl}$, or other chloride salt; the EPA method is not designed to look for salts. Increases in the acidity of the water is directly indicative of the amount of $\mathrm{HCl}$ and $\mathrm{HF}$ in the offgas. 
The halides were quantified by Ion Chromatography (IC); nitrate, sulfate, and phosphate were also measured by IC. Metals were quantified by Inductively Coupled Plasma-Atomic Emission Spectroscopy (ICP-AES). Samples containing solids were analyzed for total species by dissolving the solids with a few drops of $\mathrm{HNO}_{3}$ and also for soluble species by first filtering out the solids.

The acid impingers are designed to remove the hydrogen halide vapors, while the basic impingers remove the halogens $\left(\mathrm{Cl}_{2}\right)$. Chlorine has a very low solubility in the acidic solutions and should pass through to the alkaline solution where it is hydrolyzed to form a proton $\left(\mathrm{H}^{+}\right)$, the chloride ion, and hypochlorous acid ( $\mathrm{HClO})$ :

$$
\mathrm{Cl}_{2}+\mathrm{H}_{2} \mathrm{O} \quad \mathrm{H}^{+}+\mathrm{Cl}^{-}+\mathrm{HClO}
$$

Sodium thiosulfate is added to the alkaline solution to assure reaction with the hypochlorous acid to form a second halide ion such that two chloride ions are formed for each molecule of chlorine gas. Table 7 summarizes the sample and analyses performed. All chemical analyses except total acid were performed by the Process Science Analytical Laboratory; the total acid analyses, X-Ray Diffraction (XRD), and Scanning Electron Microscopy coupled with Energy Dispersive Spectroscopy (SEM/EDS) were performed by SRNL- Analytical Development (AD).

Table 7 Sample Preparation and Analyses

\begin{tabular}{|lll|}
\hline Sample & Preparation & Analyses \\
\hline Filter - Particulate & none & total mass \\
& & $\begin{array}{l}\text { XRD } \\
\text { SEM/EDS }\end{array}$ \\
Filter - Particulate & $\begin{array}{l}\text { dilution \& dissolution } \\
\text { (acidification) }\end{array}$ & $\begin{array}{l}\text { IC (except nitrate) } \\
\text { ICP-AES }\end{array}$ \\
Filter - Particulate & dilution \& filtration & IC \\
& & ICP-AES \\
\hline $\begin{array}{lll}\text { Water Impingers } \\
\text { (+ empty impinger) }\end{array}$ & dilution & Total Acid \\
& & IC \\
\hline Acid Impingers & dilution & TCP-AES \\
& & IC (except sulfate) \\
& & ICP-AES (except sulfur) \\
\hline Basic Impingers & dilution & IC \\
\hline Basic Impingers & reaction with sodium & IC (except sulfate) \\
& thiosulfate & \\
\hline
\end{tabular}

Based on results from monitoring by SRNL Industrial Hygiene, an offgas collection hood was fabricated and installed above the existing CIM Lexan ${ }^{\mathrm{TM}}$ shielding barriers to ensure that emissions are captured during the periods when the offgas sampling filters are being replaced (See Figure 7). A Job Hazards Analysis, ${ }^{9}$ Environmental Evaluation Checklist, ${ }^{10}$ and Safety Inspection were completed and approved by management prior to the initial offgas sampling run. 


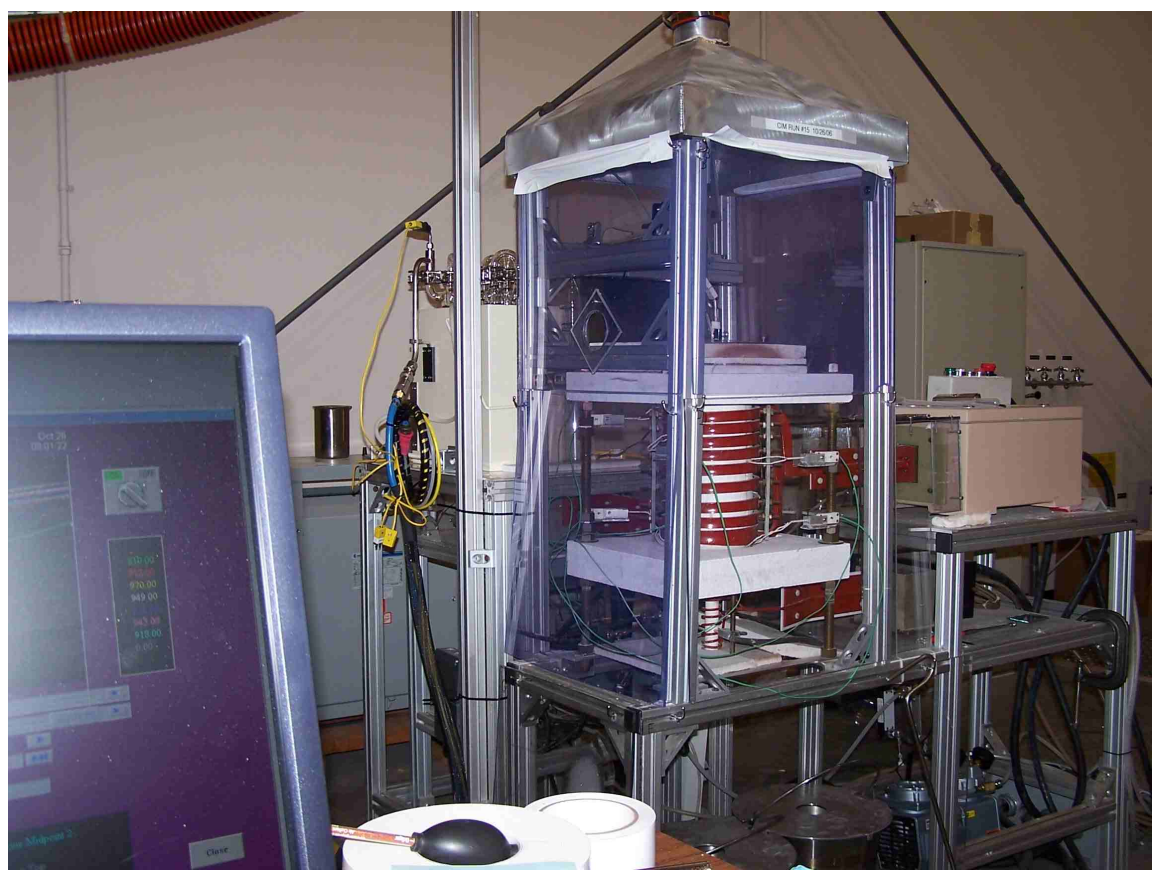

Figure 7 CIM Lexan ${ }^{\mathrm{TM}}$ Shield Barriers and Fume Hood

Three offgas sampling test runs were conducted with the CIM in this initial phase of work. In each run, LaBS Frit $\mathrm{X}$ was blended with impurities additions for the purpose of sampling the particulate and vapors emitted from the melt (see Figure 8). Information obtained from these tests will support the design of the offgas handling system required for the PDP. Information obtained in this phase will also guide follow-on experimental work. 


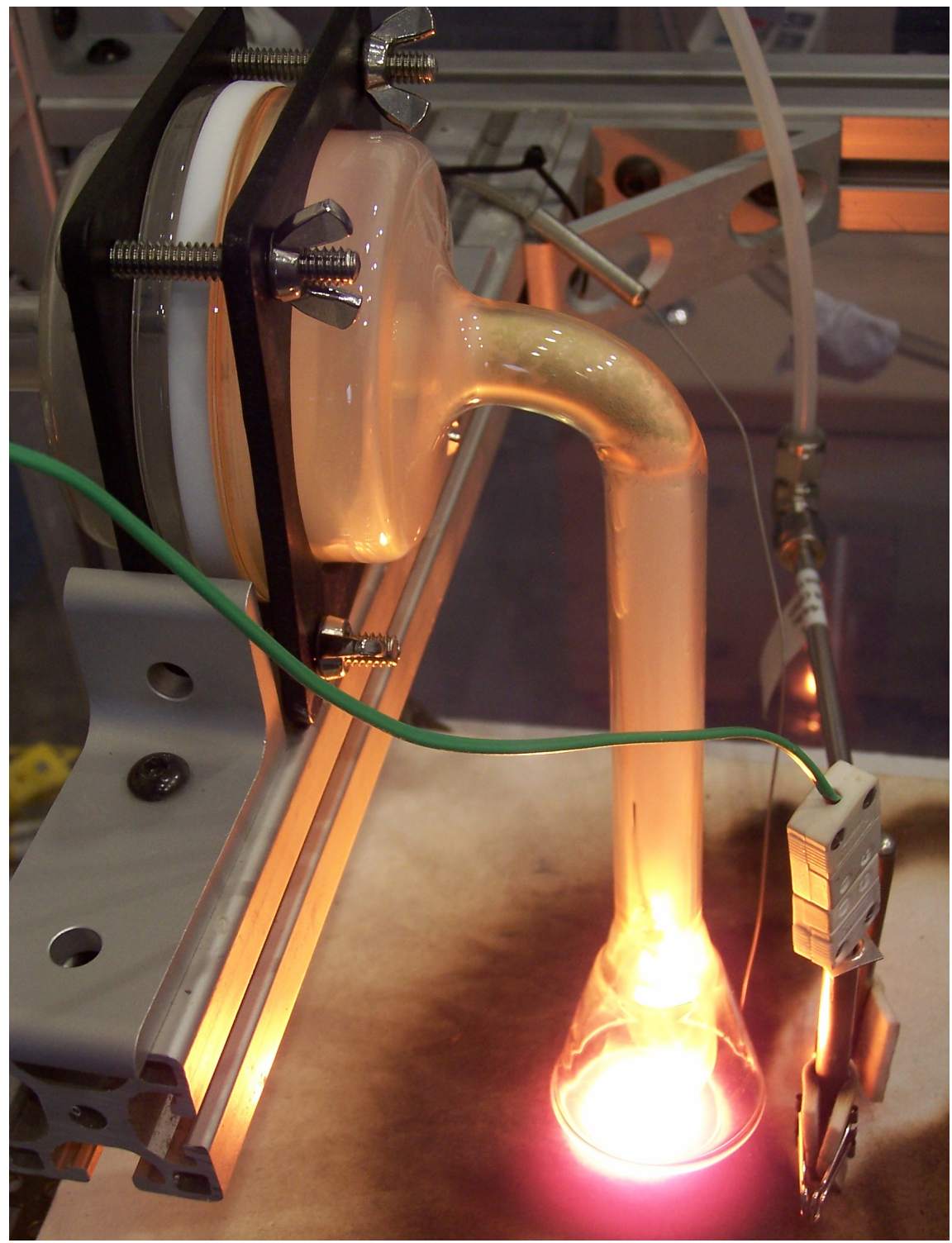

Figure 8 Offgas Emissions Quartz Collection Funnel and Filter

\subsection{Batching of Frit $\mathrm{X}$, Hafnium Oxide, and Impurities}

Three runs (Runs 14-16) of the CIM were performed with Frit $\mathrm{X}, \mathrm{HfO}_{2}$, and impurities. The first impurity run ( $\mathrm{NaCl}$ Run) included only $\mathrm{NaCl}$ as an impurity, while the second run (Rocky Flats Run) included impurities to approximate the composition of Rocky Flats can B5495. ${ }^{11}$ The third run (Remelt Run) re-melted the glass product from the Rocky Flats Run.

The mass of each feed species for the $\mathrm{NaCl}$ and Rocky Flats Runs are shown in Table 8. The total amounts of feed and the final glass mass are also given. The nominal target and measured composition of the Frit X used is shown in Table 9.

Table 8 Feed Compositions for $\mathrm{NaCl}$ and Rocky Flats Runs 


\begin{tabular}{|c|c|c|c|c|c|}
\hline \multirow[b]{2}{*}{ Component } & \multicolumn{2}{|c|}{$\mathrm{NaCl}$ Run } & \multicolumn{2}{|c|}{$\begin{array}{l}\text { Rocky Flats } \\
\text { Run }\end{array}$} & \multirow{2}{*}{$\begin{array}{l}\text { Remelt } \\
\text { Run } \\
\text { Mass } \\
\text { (g) }\end{array}$} \\
\hline & $\begin{array}{l}\text { Mass } \\
(\mathrm{g})\end{array}$ & $\begin{array}{l}\mathrm{Wt} \% \\
\text { in } \\
\text { Feed }\end{array}$ & $\begin{array}{l}\text { Mass } \\
(\mathrm{g})\end{array}$ & $\begin{array}{l}\mathrm{Wt} \% \\
\text { in } \\
\text { Feed }\end{array}$ & \\
\hline $\begin{array}{l}\text { Total Final Glass } \\
\text { (measured) }\end{array}$ & 2927.8 & NA & 2924.9 & NA & 2830.4 \\
\hline Total Initial Feed & $\begin{array}{l}3000 \\
(2981)^{\dagger}\end{array}$ & NA & 2981 & NA & 2833 \\
\hline Frit $\mathrm{X}$ & 2700 & 90.0 & 2733.3 & 91.7 & \\
\hline $\mathrm{HfO}_{2} *$ & 225 & 7.5 & 153.4 & 5.14 & NA \\
\hline$\Sigma$ Impurities & 75.0 & 2.5 & 94.28 & 3.16 & \\
\hline $\mathrm{CaCl}_{2} \cdot 2 \mathrm{H}_{2} \mathrm{O}$ & 0 & 0 & 4.76 & 0.16 & \\
\hline $\mathrm{CaF}_{2}$ & 0 & 0 & 6.56 & 0.22 & \\
\hline $\mathrm{Cr}_{2} \mathrm{O}_{3}$ & 0 & 0 & 5.46 & 0.18 & \\
\hline $\mathrm{CuO}$ & 0 & 0 & 0.304 & 0.01 & \\
\hline $\mathrm{Fe}_{2} \mathrm{O}_{3}$ & 0 & 0 & 2.98 & 0.10 & \\
\hline $\mathrm{KCl}$ & 0 & 0 & 26.93 & 0.90 & NA \\
\hline $\mathrm{MgOHCl}$ & 0 & 0 & 13.68 & 0.46 & \\
\hline $\mathrm{MoO}_{3}$ & 0 & 0 & 0.609 & 0.02 & \\
\hline $\mathrm{NaCl}$ & 75.0 & 2.5 & 26.33 & 0.88 & \\
\hline $\mathrm{NiO}$ & 0 & 0 & 4.47 & 0.15 & \\
\hline $\mathrm{Na}_{3} \mathrm{PO}_{4}$ & 0 & 0 & 0.703 & 0.024 & \\
\hline $\mathrm{WO}_{3}$ & 0 & 0 & 1.49 & 0.05 & \\
\hline
\end{tabular}

* $\mathrm{HfO}_{2}$ is present in the frit and is also used as the surrogate for $\mathrm{PuO}_{2}$.

$\dagger$ Initial mass target was $3000 \mathrm{~g}$; initial mass actually added to melter not measured; assumed to be similar to the Rocky Flats Run

Table 9 Target and Measured Composition of Frit X

Measured Measured

\begin{tabular}{|c|c|c|c|c|c|c|c|}
\hline Element & $\begin{array}{l}\text { Target } \\
\text { (wt\%) }\end{array}$ & $\begin{array}{c}1 \\
(w t \%)\end{array}$ & $\begin{array}{c}2 \\
(w t \%)\end{array}$ & $\begin{array}{l}\text { Mean } \\
(w t \%)\end{array}$ & Oxide & $\begin{array}{l}\text { Target } \\
\text { (wt\%) }\end{array}$ & $\begin{array}{l}\text { Mean } \\
(w t \%)\end{array}$ \\
\hline $\mathrm{Al}$ & 5.29 & 6.08 & 6.27 & 6.18 & $\mathrm{Al}_{2} \mathrm{O}_{3}$ & 10.00 & 11.67 \\
\hline B & 4.04 & 3.89 & 3.93 & 3.91 & $\mathrm{~B}_{2} \mathrm{O}_{3}$ & 13.00 & 12.59 \\
\hline $\mathrm{Gd}$ & 11.71 & 11.60 & 11.60 & 11.60 & $\mathrm{Gd}_{2} \mathrm{O}_{3}$ & 13.50 & 13.37 \\
\hline $\mathrm{Hf}$ & 5.94 & 5.41 & 5.66 & 5.54 & $\mathrm{HfO}_{2}$ & 7.00 & 6.53 \\
\hline $\mathrm{La}$ & 16.20 & 16.10 & 16.10 & 16.10 & $\mathrm{La}_{2} \mathrm{O}_{3}$ & 19.00 & 18.88 \\
\hline $\mathrm{Nd}$ & 12.86 & 12.30 & 12.20 & 12.25 & $\mathrm{Nd}_{2} \mathrm{O}_{3}$ & 15.00 & 14.29 \\
\hline $\mathrm{Si}$ & 9.35 & 9.66 & 9.81 & 9.74 & $\mathrm{SiO}_{2}$ & 20.00 & 20.83 \\
\hline $\mathrm{Sr}$ & 2.11 & 2.08 & 2.06 & 2.07 & $\mathrm{SrO}$ & 2.50 & 2.45 \\
\hline \multirow[t]{2}{*}{$\mathrm{Cu}$} & 0 & 0.04 & NA & 0.04 & $\mathrm{CuO}$ & NA & 0.05 \\
\hline & & & & & TOTA & 100.0 & 100.6 \\
\hline
\end{tabular}

(Cr, Fe, Ni, Ca, K, Mg, Mn, Mo, P, Pb, S, Ti, Zn, Zr all below detection limits) 
The documented composition of the Rocky Flats B5495 is compared to the actual composition of the feed used for the Rocky Flats Run (excluding the Frit X) in Table 10. Some approximations to the actual composition had to be made. The $\mathrm{Pu}$ content is a combination of $\mathrm{PuO}_{2}$ and $\mathrm{PuF}_{4} ; \mathrm{HfO}_{2}$ is used as a surrogate for $\mathrm{PuO}_{2}$ in the simulant tests, but $\mathrm{HfF}_{4}$ was not available. To add more fluorine (F), $\mathrm{CaF}_{2}$ was added, which resulted in the Ca content of the simulant being about 3.6 times higher than the target. The actual frit content of the total feed was $91.7 \mathrm{wt} \%$ versus the target $90.0 \mathrm{wt} \%$. This difference was due to unintentionally leaving out the $\mathrm{Pu}$ from $\mathrm{PuF}_{4}$ and not adding an equivalent amount of $\mathrm{Hf}$ for the $\mathrm{Pu}$. The amount of $\mathrm{HfO}_{2}$ added was equivalent to the amount of $\mathrm{PuO}_{2}$ present on a molar basis.

Magnesium chloride $\mathrm{MgCl}_{2}$ cannot be added in the anhydrous form due to its hygroscopic nature; only the hexahydrate can be used in non-inerted atmospheres. Because this impure $\mathrm{Pu}$ stream has been fired at high temperature, it was deemed likely that the $\mathrm{MgO}$ and $\mathrm{MgCl}_{2}$ could have formed the hydroxychloride $\mathrm{MgOHCl}$, so $\mathrm{MgOHCl}$ was used in place of the $\mathrm{MgO}$ and $\mathrm{MgCl}_{2}$. $\mathrm{MgOHCl}$ is also much easier to handle as it is a refractory non-hygroscopic solid. Use of $\mathrm{MgOHCl}$ resulted in the chloride content of the simulant being about $20 \%$ higher than the target.

Anhydrous sodium phosphate $\mathrm{Na}_{3} \mathrm{PO}_{4}$ was substituted for phosphorus pentoxide $\mathrm{P}_{2} \mathrm{O}_{5}$, again due to the hygroscopic nature of $\mathrm{P}_{2} \mathrm{O}_{5}$. This substitution resulted in $3 \%$ more Na than the target. Calcium chloride dihydrate $\mathrm{CaCl}_{2} \cdot 2 \mathrm{H}_{2} \mathrm{O}$ was used rather than the anhydrous form because the anhydrous material was not available.

Overall, the impurities accounted for about $38 \mathrm{wt} \%$ of the simulated $\mathrm{Pu}$ feed compared to the target value of about $29.4 \mathrm{wt} \%$. The difference is due to the substitutions described above. The Pu stream is assumed to be completely dry, but the actual amount of water associated with it is not known. No additional water was added to the simulant other than any water that was associated with the reagents and any water that may have been adsorbed during handling in the laboratory. 
Table 10 Comparison of Rocky Flats Run Feed Composition (Actual) and Documented Rocky Flats B5495 Composition (Target)

\begin{tabular}{|c|c|c|c|c|}
\hline Feed Component & $\begin{array}{c}\text { Target } \\
\text { Wt\% of } \\
\text { Feed }\end{array}$ & $\begin{array}{c}\text { Actual } \\
\text { Wt } \% \text { of } \\
\text { Feed }\end{array}$ & $\begin{array}{c}\text { Target } \\
\text { Wt } \% \text { of Feed } \\
+ \text { Frit }\end{array}$ & $\begin{array}{c}\text { Actual } \\
\text { Wt } \% \text { of Feed } \\
+ \text { Frit }\end{array}$ \\
\hline $\mathrm{Al}_{2} \mathrm{O}_{3}$ & 0.98 & NA & 0.0982 & NA \\
\hline $\mathrm{CaCl}_{2}$ & 1.18 & NA & 0.118 & NA \\
\hline $\mathrm{CaCl}_{2} \cdot 2 \mathrm{H}_{2} \mathrm{O}$ & $(1.57)^{\mathrm{a}}$ & 1.92 & NA & 0.160 \\
\hline $\mathrm{CaF}_{2}$ & & 2.65 & 0 & 0.220 \\
\hline $\mathrm{CrO}_{3}$ & 2.36 & NA & 0.236 & NA \\
\hline $\mathrm{Cr}_{2} \mathrm{O}_{3}$ & & 2.20 & 0 & 0.183 \\
\hline $\mathrm{CuO}$ & 0.100 & 0.123 & 0.010 & 0.010 \\
\hline $\mathrm{Fe}_{2} \mathrm{O}_{3}$ & 0.98 & 1.20 & 0.098 & 0.100 \\
\hline $\mathrm{KCl}$ & 8.87 & 10.9 & 0.887 & 0.904 \\
\hline $\mathrm{MgO}$ & 2.36 & NA & 0.236 & NA \\
\hline $\mathrm{MgOHCl}$ & NA & 5.52 & 0 & 0.459 \\
\hline $\mathrm{MoO}_{3}$ & 0.20 & 0.246 & 0.020 & 0.020 \\
\hline $\mathrm{NaCl}$ & 8.67 & 10.6 & 0.867 & 0.883 \\
\hline $\mathrm{NiO}$ & 1.47 & 1.81 & 0.147 & 0.150 \\
\hline $\mathrm{P}_{2} \mathrm{O}_{5}$ & 0.100 & NA & 0.010 & NA \\
\hline $\mathrm{Na}_{3} \mathrm{PO}_{4}$ & $(0.231)^{\mathrm{b}}$ & 0.284 & NA & 0.024 \\
\hline $\mathrm{SiO}_{2}$ & 1.57 & NA & 0.157 & NA \\
\hline $\mathrm{WO}_{3}$ & 0.49 & 0.602 & 0.049 & 0.050 \\
\hline $\mathrm{PuF}_{4}$ & 4.43 & NA & 0.443 & NA \\
\hline $\mathrm{PuO}_{2}$ & 66.2 & NA & 6.62 & NA \\
\hline $\mathrm{HfO}_{2}$ & NA & 61.9 & NA & 5.14 \\
\hline Frit X & NA & NA & 90.0 & 91.7 \\
\hline Total Impurities & 29.4 & 38.1 & 2.94 & 3.16 \\
\hline Impurities $+\mathrm{HfO}_{2}$ & 100 & 100 & 10.0 & 8.31 \\
\hline TOTAL & 100 & 100 & 100 & 100 \\
\hline
\end{tabular}

a $\mathrm{CaCl}_{2} \cdot 2 \mathrm{H}_{2} \mathrm{O}$ that would correspond to the $\mathrm{CaCl}_{2}$

b $\mathrm{Na}_{3} \mathrm{PO}_{4}$ that would correspond to the $\mathrm{P}_{2} \mathrm{O}_{5}$

\subsubsection{Chronology of NaCl Run}

The $\mathrm{NaCl}$ Run processed approximately $3000 \mathrm{~g}$ of feed which was charged into the CIM, resulting in a $8.5^{\prime \prime}$ bed height (of 14" total in the CIM vessel). The batch was heated to about $1400^{\circ} \mathrm{C}$ (following the standard heating rate cycle employed when producing LaBS cullet from batch chemicals). Air bubbling was then initiated at $0.75 \mathrm{scfh}$ to homogenize the glass for an additional 3 hours at $1450^{\circ} \mathrm{C}$ (per T1). During glass pouring, glass samples were collected at the initiation of pouring, mid-way into the pour, and as the final glass drips were deposited. The offgas was sampled throughout the entire vitrification run. A detailed account of the offgas sampling results is presented in Section 3.1, and events and observations are listed in Table 11. 
Table 11 NaCl Run Events/Observations

\begin{tabular}{|ccc|l|}
\hline $\begin{array}{c}\text { Elapsed Run } \\
\text { Time } \\
(\mathbf{m i n})\end{array}$ & $\begin{array}{c}\text { Vessel } \\
\text { Temp (T4) } \\
\left.\mathbf{(}^{\mathbf{}} \mathbf{C}\right)\end{array}$ & $\begin{array}{c}\text { Bed Temp } \\
\mathbf{( T 1 )} \\
\mathbf{( { } ^ { \circ } \mathbf { C } )}\end{array}$ & Run Feature / Observation \\
\hline 0 & 18 & 18 & $\sim 3000 \mathrm{~g}$ batch - begin heating at $0 / 4095$ \\
\hline 30 & 248 & 57 & Set induction heating power to $350 / 4095$ \\
\hline 31 & 264 & 60 & Initiate temp ramping at $5-10^{\circ} \mathrm{C} / \mathrm{min}$. \\
\hline 164 & 1129 & 975 & OG emissions visible - captured \\
\hline 194 & 1271 & 1216 & Visible salt deposits in OG collection \\
\hline 226 & 1399 & 1389 & Initiate air bubbler at 0.75 scfh \\
\hline 232 & 1404 & 1445 & $1^{\text {st }}$ OG filter change out \\
\hline 294 & 1407 & 1458 & Impinger set $/ 2^{\text {nd }}$ OG filter change out \\
\hline 398 & 1405 & 1457 & $2^{\text {nd }}$ Impinger set $/ 3^{\text {rd }}$ OG filter change \\
\hline 413 & 1404 & 1457 & Initiate drain tube heating \\
\hline 421 & 1404 & 1461 & Glass pouring began - pour sample $\# 1$ \\
\hline 425 & 1407 & 1463 & Pour sample $\# 2$ collected \\
\hline 426 & 1409 & 1463 & Pour concluded - pour sample $\# 3$ \\
\hline 427 & 1412 & 1463 & OG sampling concluded \\
\hline
\end{tabular}

\subsubsection{Chronology of Rocky Flats Run}

The Rocky Flats Run (Run 15) processed a $2981 \mathrm{~g}$ batch consisting of LaBS Frit X with chemical additions representative of a Rocky Flats Can B5495 composition. The same heating and sampling schedule was followed as was employed with the previous $\mathrm{NaCl}$ addition test. The offgas was sampled throughout the entire vitrification run. Particulate and vapors were still evident by visual observation at the completion of three hours air bubbling at $1450^{\circ} \mathrm{C}$. Part way through the run, the bubbler air flow was reduced to about $0.35 \mathrm{scfh}$ to see if the lower flowrate would visibly change the appearance of the offgas particulate emissions. No noticeable change occurred. During glass pouring, glass samples were collected at the initiation of pouring, mid-way into the pour, and as the final glass drips were deposited. A detailed account of the offgas sampling is presented in Section 3.1, and events and observations are listed in Table 12. 
Table 12 Rocky Flats Run Events/Observations

\begin{tabular}{|ccc|l|}
\hline $\begin{array}{c}\text { Elapsed Run } \\
\text { Time } \\
(\mathbf{m i n})\end{array}$ & $\begin{array}{c}\text { Vessel } \\
\text { Temp (T4) } \\
\mathbf{(} \mathbf{C})\end{array}$ & $\begin{array}{c}\text { Bed Temp } \\
\mathbf{( T 1 )} \\
\mathbf{(} \mathbf{C})\end{array}$ & Run Feature / Observation \\
\hline 0 & 19 & 65 & 2981g batch - begin heating at $0 / 4095$ \\
\hline 30 & 251 & 97 & Set induction heating power to $350 / 4095$ \\
\hline 31 & 267 & 101 & Initiate temp ramping at $5-10^{\circ} \mathrm{C} / \mathrm{min}$. \\
\hline 126 & 899 & 680 & Deposits on OG filter and glass funnel \\
\hline 179 & 1179 & 1125 & Visible dense vapor emission from melter \\
\hline 198 & 1287 & 1231 & $1^{\text {st }}$ OG filter change out \\
\hline 219 & 1382 & 1366 & Initiate air bubbler at 0.75 scfh \\
\hline 227 & 1390 & 1435 & Reduced bubbler flow to 0.35 scfh \\
\hline 230 & 1390 & 1441 & $2^{\text {nd }}$ OG filter change out \\
\hline 283 & 1373 & 1434 & Change out impinger set \\
\hline 345 & 1371 & 1432 & $3^{\text {rd }}$ OG filter change out \\
\hline 380 & 1371 & 1433 & $4^{\text {th }}$ OG filter change out \\
\hline 396 & 1371 & 1432 & Initiate drain tube heating \\
\hline 413 & 1372 & 1434 & Glass pouring began - pour sample \#1 \\
\hline 416 & 1375 & 1435 & Pour sample \#2 collected \\
\hline 419 & 1376 & 1436 & Pour concluded - pour sample \#3 \\
\hline 420 & 1376 & 1436 & OG sampling concluded \\
\hline & & & \\
\hline
\end{tabular}

\subsubsection{Chronology Remelt Run}

The Remelt Run (Run 16) processed the glass produced as the product from the Rocky Flats Run. At the completion of three hours of air bubbling in the glass pool at $1450^{\circ} \mathrm{C}$ in the Rocky Flats Run, particulate and vapors were still being emitted by the melt. Therefore, for the Remelt Run, the glass from the Rocky Flats Run was reheated in the CIM to $1450^{\circ} \mathrm{C}$, mixed by air bubbling at $0.75 \mathrm{scfh}$ for three hours, and offgas emissions sampled throughout the run. During glass pouring, glass samples were collected as with prior offgas sampling test runs. A detailed account of the offgas sampling is presented in Section 3.1, and events and observations are listed in Table 13. 
Table 13 Remelt Run Events/Observations

\begin{tabular}{|ccc|l|}
\hline $\begin{array}{c}\text { Elapsed Run } \\
\text { Time } \\
(\mathbf{m i n})\end{array}$ & $\begin{array}{c}\text { Vessel Temp } \\
\mathbf{( T 4 )} \\
\left(\mathbf{}^{\mathbf{O}} \mathbf{C}\right)\end{array}$ & $\begin{array}{c}\text { Bed Temp } \\
\mathbf{( T 1 )} \\
\mathbf{( { } ^ { \mathbf { } } \mathbf { C } )}\end{array}$ & Run Feature / Observation \\
\hline 0 & 38 & 17 & 2833g glass - begin heating at $0 / 4095$ \\
\hline 30 & 249 & 102 & Set induction heating power to $350 / 4095$ \\
\hline 31 & 266 & 105 & Initiate temp ramping at $5-10^{\circ} \mathrm{C} / \mathrm{min}$. \\
\hline 165 & 1123 & 1058 & Yellow/brown deposits on OG filter \\
\hline 175 & 1177 & 1121 & Visible deposits on OG glass funnel \\
\hline 220 & 1375 & 1386 & Initiate air bubbler at 0.75 scfh \\
\hline 248 & 1390 & 1455 & $1^{\text {st }}$ OG filter change out \\
\hline 350 & 1379 & 1447 & $2^{\text {nd }}$ OG filter change out \\
\hline 400 & 1378 & 1448 & Initiate drain tube heating \\
\hline 400 & 1378 & 1448 & OG emissions greatly reduced \\
\hline 420 & 1378 & 1450 & Glass pouring began - pour sample \#1 \\
\hline 423 & 1381 & 1451 & Pour sample \#2 collected \\
\hline 425 & 1382 & 1450 & Pour concluded - pour sample \#3 \\
\hline 426 & 1382 & 1450 & OG sampling concluded \\
\hline
\end{tabular}

\subsection{RESULTS}

\subsection{Offgas Sampling Results}

The offgas samples were collected and analyzed as described in Section 2.3.2. The results are documented in laboratory notebook WSRC-NB-2006-00030 ${ }^{12}$. For each run, several particulate samples were taken for each of one or two sets of impingers, as summarized in Table 14.

Table 14 Summary of Sampling Sets

\begin{tabular}{|c|c|c|}
\hline Run & $\begin{array}{c}\text { Impinger } \\
\text { Sets }\end{array}$ & $\begin{array}{c}\text { Particulate } \\
\text { Filters }\end{array}$ \\
\hline NaCl Run & 2 & 4 \\
Rocky Flats Run & 2 & 6 \\
Remelt Run & 1 & 3 \\
\hline
\end{tabular}

The amounts of each offgas species (element) collected per $\mathrm{kg}$ of glass produced in the Rocky Flats Run are shown in Table 15. The fraction as $\mathrm{wt} \%$ of each species present in the feed that was evolved to the offgas is also given. Based on the chemical analyses, about $1.72 \mathrm{wt} \%$ of the feed was volatilized to the offgas system; based on the mass loss from the feed to glass (feed mass minus glass mass), the amount volatilized is estimated to be $1.92 \mathrm{wt} \%$. Of the total impurity addition of $3.16 \mathrm{wt} \%$, the offgas species constitute $54-61 \%$ of the impurities. The major constituents in the offgas particulate were $\mathrm{Cl}, \mathrm{K}$, and $\mathrm{Na}$, while $\mathrm{Cl}$ and $\mathrm{F}$ predominated in the offgas scrub solutions. All of the frit components were found in very low concentrations in the offgas. Except for Hf and boron (B), all were less than $0.03 \mathrm{wt} \%$ in the offgas. $\mathrm{Hf}$ is likely to be higher due to physical entrainment of $\mathrm{HfO}_{2}$ particles while boron is higher due to the known volatility of boron at the melter temperatures. To check whether physical entrainment of $\mathrm{HfO}_{2}$ is likely, particle size analysis of the $\mathrm{HfO}_{2}$ will be performed and documented in a future report. The decontamination factors (DF) for the melter to offgas are also given. The sum of the elements for the particulate $(6541 \mathrm{mg} / \mathrm{kg})$ was very close to the particulate mass measured $(6051 \mathrm{mg} / \mathrm{kg})$. 
Table 15 Offgas Species Collected from the Rocky Flats Run

Shaded components are Frit X species

\begin{tabular}{|c|c|c|c|c|c|}
\hline & $\begin{array}{c}\text { Offgas } \\
\text { Particulate } \\
\text { (mg/kg glass) }\end{array}$ & $\begin{array}{c}\text { Offgas } \\
\text { Scrubbers } \\
\text { Total } \\
\text { (mg/kg glass) } \\
\end{array}$ & $\begin{array}{l}\text { Offgas Total } \\
(\mathrm{mg} / \mathrm{kg} \text { glass) }\end{array}$ & $\begin{array}{c}\text { Offgas } / \\
\text { Feed } \\
\left(w t^{\circ} \%\right) \\
\end{array}$ & \begin{tabular}{|c} 
Decontamination \\
Factor
\end{tabular} \\
\hline $\begin{array}{c}\text { Mass Loss } \\
\text { (Feed - Glass) }\end{array}$ & NA & NA & 19146 & 1.92 & NA \\
\hline Mass Measured & 6051 & NA & NA & NA & NA \\
\hline$\Sigma$ Elements & 6541 & 5565 & 12107 & 1.72 & 58.0 \\
\hline $\mathrm{Cl}+\mathrm{F}$ & 3098 & 5510 & 8608 & 62.0 & 1.61 \\
\hline $\mathrm{K}+\mathrm{Na}$ & 2830 & 29.7 & 2860 & 34.2 & 2.93 \\
\hline $\mathrm{Cl}$ & 3086 & 5337 & 8422 & 65.9 & 1.52 \\
\hline $\mathrm{Cu}$ & 47.8 & 0.50 & 48.3 & 58.2 & 1.72 \\
\hline $\mathrm{K}$ & 2101 & 17.8 & 2118 & 43.9 & 2.28 \\
\hline Mo & 32.0 & 1.60 & 33.6 & 24.3 & 4.12 \\
\hline $\mathrm{Na}$ & 730 & 11.9 & 742 & 20.9 & 4.77 \\
\hline $\mathrm{Ni}$ & 241 & 2.71 & 243 & 20.2 & 4.94 \\
\hline $\mathrm{F}$ & 12.2 & 173 & 185 & 17.0 & 5.89 \\
\hline $\mathrm{Fe}$ & 24.4 & 0.45 & 24.8 & 3.48 & 28.7 \\
\hline $\mathrm{Cr}$ & 37.9 & 6.09 & 43.9 & 3.44 & 29.1 \\
\hline W & 5.50 & 0.19 & 5.69 & 1.41 & 71.1 \\
\hline $\mathrm{Ca}$ & 2.10 & 0.20 & 2.30 & 0.52 & 192 \\
\hline $\mathrm{P}$ & 0.09 & 0 & 0.09 & 0.20 & 510 \\
\hline $\mathrm{B} \dagger$ & 52.1 & 7.38 & 59.5 & 0.16 & 614 \\
\hline Hf & 156 & 0.03 & 156 & 0.16 & 615 \\
\hline $\mathrm{Mg}$ & 0.64 & 0 & 0.64 & 0.043 & 2316 \\
\hline $\mathrm{Sr}$ & 5.73 & 0.11 & 5.85 & 0.030 & 3309 \\
\hline $\mathrm{Si} \dagger$ & 0.26 & 4.76 & 5.03 & 0.0055 & $1.81 \mathrm{E}+04$ \\
\hline $\mathrm{Al}$ & 1.33 & 0.24 & 1.57 & 0.0027 & $3.66 \mathrm{E}+04$ \\
\hline $\mathrm{La}$ & 0.59 & 0 & 0.59 & 0.00039 & $2.56 \mathrm{E}+05$ \\
\hline Gd & 0.31 & 0 & 0.31 & 0.00029 & $3.46 \mathrm{E}+05$ \\
\hline $\mathrm{Nd}$ & 0.31 & 0 & 0.31 & 0.00027 & $3.69 \mathrm{E}+05$ \\
\hline $\mathrm{Pb}^{*}$ & 0.54 & 0 & 0.54 & NA & NA \\
\hline S* & 1.11 & 1.78 & 2.89 & NA & NA \\
\hline $\mathrm{Zn} *$ & 3.54 & 0 & 3.54 & NA & NA \\
\hline
\end{tabular}

$*$ not added to feed $\uparrow \mathrm{B} \& \mathrm{Si}$ in scrubbers possibly from glassware

Table 16 shows the offgas species collected in the $\mathrm{NaCl}$ Run. Based on the chemical analyses, about $1.79 \mathrm{wt} \%$ of the feed was volatilized to the offgas system, while the amount volatilized based on the feed and glass masses was $1.82 \mathrm{wt} \%$. These amounts correspond to an impurity loss of $\sim 72 \%$ of the added $2.5 \mathrm{wt} \%$. The losses of $\mathrm{Na}$ and $\mathrm{Cl}$ were similar to the values found for the Rocky Flats Run. The DFs for boron and Sr were again the highest for the frit components. The species with NA for the decontamination factor were not intentionally added to the feed, but some were present nonetheless. The elements $\mathrm{K}, \mathrm{Fe}$, and $\mathrm{Cu}$ were present at higher than expected amounts. The $\mathrm{K}$ may have been an impurity in the $\mathrm{NaCl}$ used. The source of $\mathrm{Fe}$ may be from blending of the frit and $\mathrm{HfO}_{2}$ in ferrous metal equipment or from the $\mathrm{HfO}_{2}$ used (99\% pure). Frit analysis (prior to blending) showed no detectable $\mathrm{Fe}$. The $\mathrm{HfO}_{2}$ has not been analyzed for impurities. The $\mathrm{Cu}$ could have come from frit screening on brass sieves. Brass contains both $\mathrm{Cu}$ and $\mathrm{Zn}$, and $\mathrm{Zn}$ was found in the offgas particulate even though it was not added; the ratio of $\mathrm{Zn}: \mathrm{Cu}$ was 0.25 which is in the range of a typical brass. 
Table 16 Offgas Species Collected from the NaCl Run

Shaded components are Frit X species

\begin{tabular}{|c|c|c|c|c|c|}
\hline & $\begin{array}{c}\text { Offgas } \\
\text { Particulate } \\
\text { (mg/kg glass) }\end{array}$ & $\begin{array}{c}\text { Offgas } \\
\text { Scrubbers } \\
\text { Total } \\
\text { (mg/kg } \\
\text { glass) }\end{array}$ & $\begin{array}{c}\text { Offgas } \\
\text { Total } \\
\text { (mg/kg } \\
\text { glass) }\end{array}$ & $\begin{array}{c}\text { Offgas / } \\
\text { Feed } \\
\left(w t^{0} \%\right)\end{array}$ & $\begin{array}{c}\text { Decontamination } \\
\text { Factor }\end{array}$ \\
\hline $\begin{array}{c}\text { Mass Loss } \\
\text { (Feed - Glass) }\end{array}$ & NA & NA & 18171 & 1.82 & NA \\
\hline Mass Measured & 3354 & NA & NA & NA & NA \\
\hline$\Sigma$ Elements & 6725 & 6041 & 12767 & 1.79 & 55.8 \\
\hline $\mathrm{Cl}$ & 3973 & 6028 & 10001 & 64.4 & 1.55 \\
\hline $\mathrm{Na}$ & 2632 & 0 & 2632 & 26.1 & 3.83 \\
\hline $\mathrm{B} \dagger$ & 42.1 & 5.65 & 47.7 & 0.13 & 756 \\
\hline $\mathrm{Sr}$ & 18.1 & 0.085 & 18.1 & 0.095 & 1052 \\
\hline $\mathrm{Al}$ & 1.00 & 0.100 & 1.10 & 0.0019 & $5.16 \mathrm{E}+04$ \\
\hline $\mathrm{La}$ & 1.59 & 0 & 1.59 & 0.0011 & $9.31 \mathrm{E}+04$ \\
\hline $\mathrm{Nd}$ & 1.07 & 0 & 1.07 & 0.00095 & $1.06 \mathrm{E}+05$ \\
\hline Hf & 1.08 & 0.006 & 1.09 & 0.00093 & $1.07 \mathrm{E}+05$ \\
\hline Gd & 0.826 & 0 & 0.826 & 0.00077 & $1.30 \mathrm{E}+05$ \\
\hline $\mathrm{Si} \dagger$ & 0.234 & 0.128 & 0.363 & 0.00040 & $2.48 \mathrm{E}+05$ \\
\hline $\mathrm{K}$ & 24.7 & 0.178 & 24.8 & NA & NA \\
\hline $\mathrm{Fe}$ & 12.3 & 0.029 & 12.3 & NA & NA \\
\hline $\mathrm{Cu}$ & 8.85 & 0.041 & 8.89 & NA & NA \\
\hline $\mathrm{Zn}$ & 2.30 & 0 & 2.30 & NA & NA \\
\hline $\mathrm{Ca}$ & 1.70 & 0.180 & 1.88 & NA & NA \\
\hline $\mathrm{Ni}$ & 1.08 & 0 & 1.08 & NA & NA \\
\hline $\mathrm{S}$ & 0.905 & 4.31 & 5.21 & NA & NA \\
\hline W & 0.725 & 0.044 & 0.769 & NA & NA \\
\hline $\mathrm{Pb}$ & 0.668 & 0 & 0.668 & NA & NA \\
\hline $\mathrm{Cr}$ & 0.331 & 0.013 & 0.345 & NA & NA \\
\hline Mo & 0.266 & 0.027 & 0.293 & NA & NA \\
\hline $\mathrm{Mg}$ & 0.245 & 0 & 0.245 & NA & NA \\
\hline $\mathrm{P}$ & 0 & 0 & 0 & NA & NA \\
\hline $\mathrm{F}$ & 0 & 2.77 & 2.77 & NA & $\mathrm{NA}$ \\
\hline
\end{tabular}

Elements below $\mathrm{K}$ in table not added to feed. $\quad$ B \& Si in scrubbers possibly from glassware

In Table 17, the total and soluble particulate from the filter samples for the Rocky Flats Run are shown. The species that were mostly insoluble were $\mathrm{Al}, \mathrm{Fe}, \mathrm{Mo}, \mathrm{W}$ and phosphate. The elements $\mathrm{F}$, $\mathrm{Cr}$, and $\mathrm{K}$ were partially soluble, while $\mathrm{Cl}, \mathrm{B}, \mathrm{Cu}, \mathrm{Ni}, \mathrm{Na}$, and $\mathrm{Sr}$ were completely soluble.

The offgas scrub solutions contained primarily $\mathrm{HCl}$ and $\mathrm{HF}$, with a small amount of alkali. Overall, the amount of alkali and other metals found in the scrubbers was very small, indicating that the particulate filter efficiency was high. Subtracting the $\mathrm{Cl}$ and $\mathrm{F}$ from the offgas scrubber total and adding back $\mathrm{Cl}$ equivalent to the $\mathrm{Na}$ and $\mathrm{K}$ present (balance $\mathrm{Na}^{+} \& \mathrm{~K}^{+}$with $\mathrm{Cl}^{-}$) gives about $90 \mathrm{mg}$ "non $\mathrm{HCl}$ or $\mathrm{HF}$ " $/ \mathrm{kg}$ glass in the scrub solutions. This means that other than $\mathrm{HCl}$ and $\mathrm{HF}$, only about $0.8 \%(90 / 11582)$ of the species volatilized were collected in the scrub solutions while $99.2 \%$ were collected on the filter. 
Table 17 Total and Soluble Particulate from the Rocky Flats Run

Total Soluble Particulate Particulate Filtrate/ Solubility in

\begin{tabular}{|c|ccc|l|}
\multicolumn{1}{r}{ Species } & $(\mathrm{g})$ & $(\mathrm{g})$ & Total $(\mathrm{wt} \%)$ & \multicolumn{1}{|c|}{ Water } \\
\hline $\mathrm{Cl}$ & 9.02 & 8.67 & 96.0 & completely \\
\hline $\mathrm{F}$ & 0.0358 & 0.0225 & 62.9 & partially \\
\hline $\mathrm{PO}_{4}^{-3}$ & 1.43 & 0.0805 & 5.6 & insoluble \\
\hline $\mathrm{Al}$ & 0.0039 & 0.0010 & 25.6 & mostly insoluble \\
\hline $\mathrm{B}$ & 0.152 & 0.150 & 98.6 & completely \\
$\mathrm{Ca}$ & 0.0036 & 0.0061 & 171 & completely * \\
\hline $\mathrm{Cr}$ & 0.111 & 0.0745 & 67.3 & partially \\
\hline $\mathrm{Cu}$ & 0.139 & 0.140 & 101 & completely \\
\hline $\mathrm{Fe}$ & 0.0713 & 0.0123 & 17.2 & mostly insoluble \\
\hline $\mathrm{K}$ & 6.14 & 3.71 & 60.4 & partially \\
\hline $\mathrm{Mo}$ & 0.0937 & 0.0122 & 13.0 & mostly insoluble \\
\hline $\mathrm{Na}$ & 2.13 & 2.09 & 97.7 & completely \\
\hline $\mathrm{Ni}$ & 0.529 & 0.704 & 133 & completely $*$ \\
\hline $\mathrm{Sr}$ & 0.0139 & 0.0168 & 121 & completely $*$ \\
\hline $\mathrm{W}$ & 0.0161 & 0.0007 & 4.1 & insoluble \\
\hline
\end{tabular}

* maximum is $100 \%$; values exceed $100 \%$ due to analytical uncertainty

The total offgas particulate and the approximate emission rate for all three runs are shown in Figure 9. The amount of particulate collected at any particular time is very similar for the $\mathrm{NaCl}$ and Rocky Flats Runs even though the composition of the impurities was different. The particulate evolution rate for the Remelt Run, which used the glass product from the Rocky Flats Run, was very close to the ending rate in the Rocky Flats Run $(\sim 0.8 \mathrm{~g} / \mathrm{kg}$ glass $/ \mathrm{h})$. The maximum particulate rate was about $2.6 \mathrm{~g} / \mathrm{kg}$ glass $/ \mathrm{h}$.

The starting temperatures for the first evidence of particulate emission in each run are interesting. The Rocky Flats Run with the variety of impurities began emitting visible particulate at about $680^{\circ} \mathrm{C}$, while the $\mathrm{NaCl}$ Run with only $\mathrm{NaCl}$ began at $980^{\circ} \mathrm{C}$, suggesting that some of the impurities in the Rocky Flats Run may be more volatile than $\mathrm{NaCl}$. The Remelt Run had a longer delay until particulate evolution began at $1170^{\circ} \mathrm{C}$. A higher temperature may have been required to release salts embedded in the glass matrix versus the previous runs where the salts were mixed with the glass frit. Figure 10 and Figure 11 show the emission rates for specific elements and also for the fluoride and chloride vapor ( $\mathrm{HF}, \mathrm{HCl})$. 


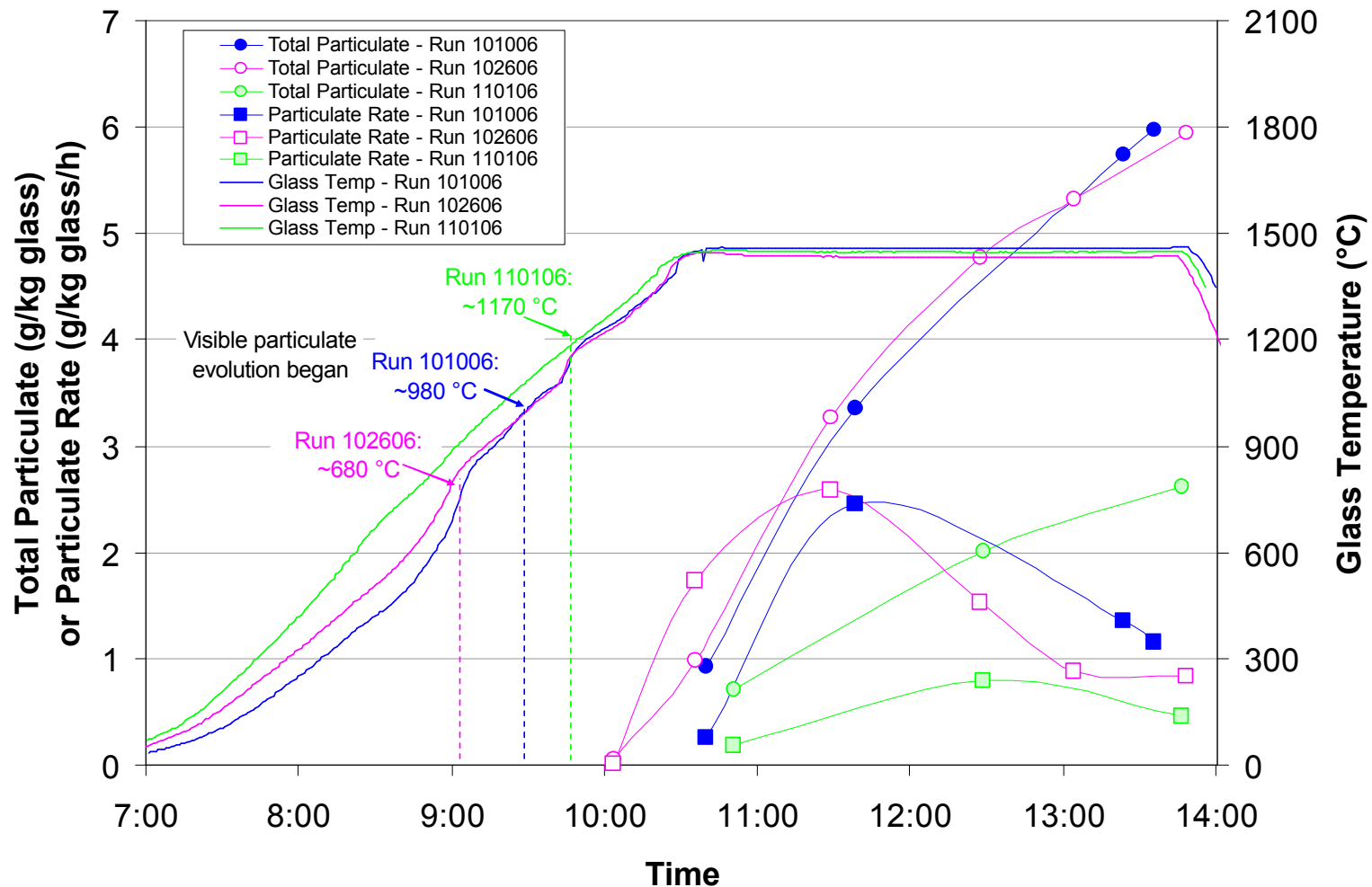

Figure 9 Offgas Particulate Evolution

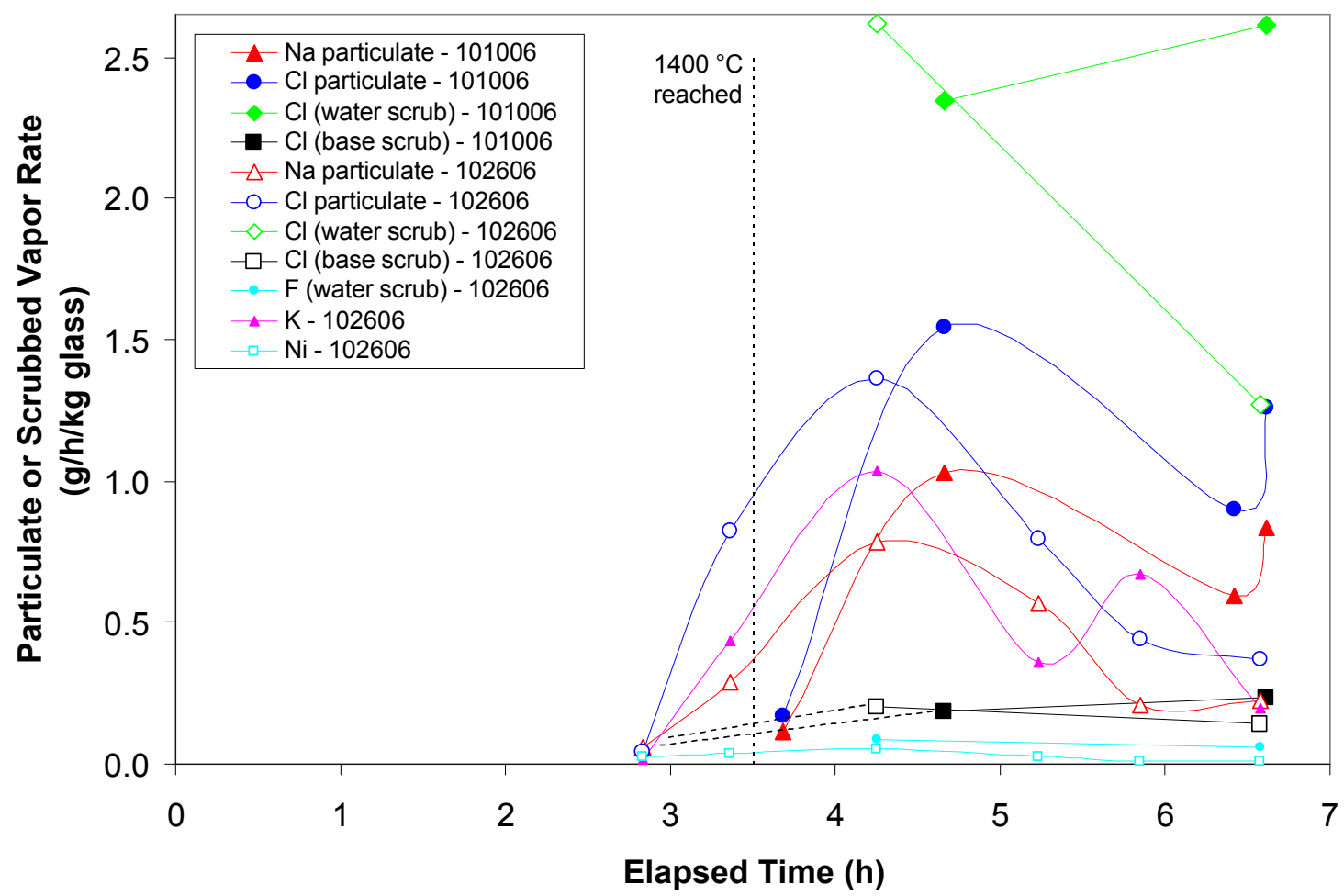

Figure 10 Particulate $\mathrm{K}, \mathrm{Na}, \mathrm{Ni}, \mathrm{Cl}$ and $\mathrm{Cl}, \mathrm{F}$ Vapor Emission Rates for the $\mathrm{NaCl}$ and Rocky Flats Runs 


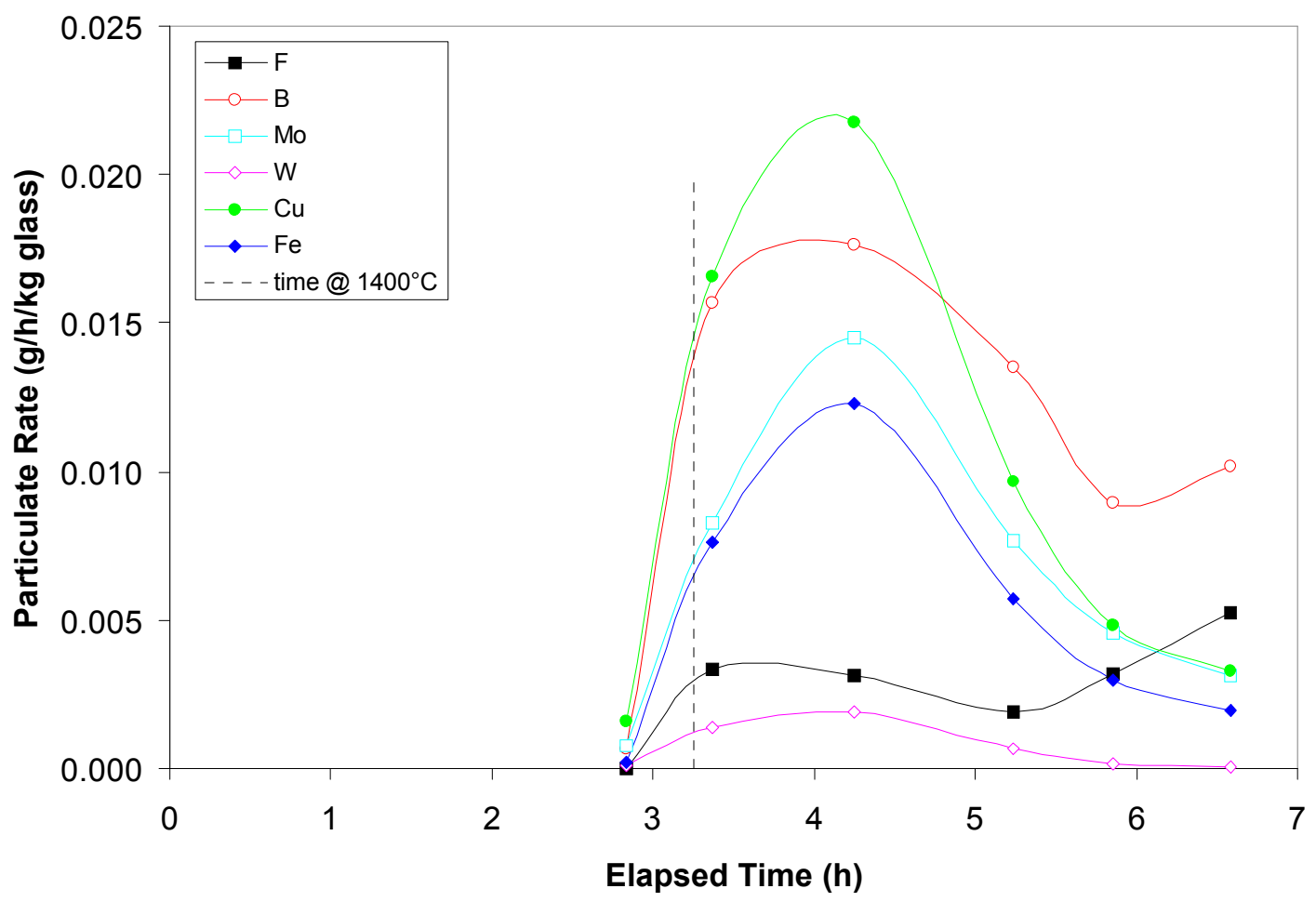

Figure 11 Particulate F, B, Mo, W, Cu and Fe Emission Rates for the Rocky Flats Run

The data in Table 18 show that the total number of moles of alkali $(\mathrm{Na}, \mathrm{K})$ collected on the filter papers for the Rocky Flats Run is equal to the moles of halides $(\mathrm{Cl}, \mathrm{F})$ collected to within $2.4 \%$. This result indicates that there was very little acid $(\mathrm{HCl}$ or $\mathrm{HF})$ on the filter papers. The $\mathrm{pH}$ of the filter paper solutions (3.4-5.3) indicates that the maximum acid concentration was about $2.5 \times 10^{-4} \mathrm{M}$. Both the $\mathrm{pH}$ data and the halide concentrations in the water impingers show that $\mathrm{HCl}$ and $\mathrm{HF}$ were produced in the melter. The very low alkali concentrations for the water impingers show that little salt passed through the filter papers into the water impingers. The data in Table 20 show that the chloride collected from the offgas was approximately the same for both runs. The sampling duration for the second impinger sets was about half the first set, but the chloride collected was greater. The rate during the second impinger sets was 2.4 to 3.5 times higher than during the first impinger sets.

The same results for alkali are shown for the $\mathrm{NaCl}$ run in Table 19. Again the moles of $\mathrm{Na}$ and $\mathrm{Cl}$ are essentially the same for the particulate. The amounts of $\mathrm{Cl}$ and the $\mathrm{pH}$ of the impingers are also similar to the Rocky Flats Run results.

Some salts were observed to pass through an apparent hole in filter $\# 5$, and the amount of $\mathrm{Na}$ in impinger set \#2 (corresponding to filters \#4-6) was about $45 \mathrm{mg} / \mathrm{L}$ versus $\sim 1 \mathrm{mg} / \mathrm{L}$ for set \#1. The presence of $\mathrm{HCl}$ and $\mathrm{HF}$ in the offgas indicates that the $\mathrm{NaCl}, \mathrm{KCl}$, and $\mathrm{CaF}_{2}$ decompose such that some amount the cation $\mathrm{Na}, \mathrm{K}$ or $\mathrm{Ca}$ is retained in the glass, resulting in the $\mathrm{Cl}$ and $\mathrm{F}$ being evolved as $\mathrm{HCl}, \mathrm{Cl}_{2}$, or $\mathrm{HF}$. 
Table 18 Alkali and Halides Collected in the Rocky Flats Run

\begin{tabular}{|c|c|c|c|c|c|c|c|}
\hline \multirow[b]{2}{*}{ Sample } & \multicolumn{6}{|c|}{ Species (mmol) } & \multirow[b]{2}{*}{$\mathrm{pH}^{\mathrm{a}}$} \\
\hline & $\mathrm{Cl}$ & $\mathbf{F}$ & $\mathbf{C l}+\mathbf{F}$ & $\mathbf{K}$ & $\mathbf{N a}$ & $\mathbf{K}+\mathbf{N a}$ & \\
\hline Filter \# 1 & 9.78 & 0 & 9.78 & 3.12 & 2.63 & 5.75 & 4.5 \\
\hline Filter \# 2 & 36.2 & 0.274 & 36.5 & 17.3 & 12.5 & 29.8 & 3.6 \\
\hline Filter \# 3 & 99.3 & 0.427 & 99.7 & 68.3 & 34.1 & 102 & 3.4 \\
\hline Filter \# 4 & 64.5 & 0.289 & 64.8 & 26.7 & 24.7 & 51.4 & 3.8 \\
\hline Filter \# 5 & 22.3 & 0.303 & 22.7 & 31.0 & 9.09 & 40.1 & 4.5 \\
\hline Filter \# 6 & 22.4 & 0.591 & 23.0 & 10.7 & 9.77 & 20.5 & 5.3 \\
\hline Total Filters & 254 & 1.88 & 256 & 157 & 92.8 & 250 & NA \\
\hline Water Impingers & 397 & 26.6 & 424 & 0.823 & 0.908 & 1.73 & $0.2,0.7$ \\
\hline Acid Impingers & 6.20 & 0 & 6.20 & 0.510 & 0.606 & 1.12 & $1.7,1.5$ \\
\hline Base Impingers ${ }^{\mathrm{b}}-\mathrm{Cl}^{-}, \mathrm{F}^{-}$ & 33.4 & 0 & 33.4 & NA & NA & NA & $4.8,12.0$ \\
\hline Base Impingers ${ }^{\mathrm{c}}-\mathrm{Cl}^{-}=2 \times \mathrm{Cl}_{2}$ & 36.7 & NA & 36.7 & NA & NA & NA & NA \\
\hline TOTAL & 695 & 28.5 & 723 & 158 & 94.4 & 253 & NA \\
\hline
\end{tabular}

${ }^{a} \mathrm{pH}$ of filtered solids in $\sim 400 \mathrm{~mL}$ water; or of impinger liquid before dilution (sets $1 \& 2$ )

${ }^{\mathrm{b}} \mathrm{Cl}^{-}$primarily from $\mathrm{Cl}_{2}$ by Eq. 1

${ }^{c}$ measured $\mathrm{Cl}^{-}$after reduction by thiosulfate

Table 19 Alkali and Halides Collected in the NaCl Run

\begin{tabular}{|c|c|c|c|}
\hline \multirow[b]{2}{*}{ Sample } & \multicolumn{2}{|c|}{ Species (mmol) } & \multirow[b]{2}{*}{$\mathbf{p H}^{\mathrm{a}}$} \\
\hline & $\mathbf{C l}$ & $\mathbf{N a}$ & \\
\hline Filter \# 1 & 52.1 & 52.5 & 4.4 \\
\hline Filter \# 2 & 125 & 129 & 6.2 \\
\hline Filter \# 3 & 130 & 132 & 8.2 \\
\hline Filter \# 4 & 20.8 & 21.3 & 8.5 \\
\hline Total Filters & 328 & 335 & NA \\
\hline Water Impingers & 452 & 0 & $0.2,0.9$ \\
\hline Acid Impingers & 2.6 & 0 & $1.8,1.4$ \\
\hline Base Impingers ${ }^{b}-\mathrm{Cl}^{-}, \mathrm{F}^{-}$ & 36.9 & NA & $4.6,10.5$ \\
\hline Base Impingers $^{\mathrm{c}}-\mathrm{Cl}^{-}=2 \times$ & 43.2 & NA & NA \\
\hline TOTAL & 826 & 335 & NA \\
\hline
\end{tabular}

${ }^{\mathrm{a}} \mathrm{pH}$ of filtered solids in $\sim 400 \mathrm{~mL}$ water; or of impinger liquid before dilution (sets $1 \& 2$ )

${ }^{\mathrm{b}} \mathrm{Cl}^{-}$primarily from $\mathrm{Cl}_{2}$ by Eq. 1

${ }^{\mathrm{c}}$ measured $\mathrm{Cl}^{-}$after reduction by thiosulfate 
Table 20 Distribution Chlorides between Impingers

\begin{tabular}{|r|c|c|c|c|}
\hline Impinger & $\begin{array}{c}\text { Racl Run } \\
\text { Chloride (g) }\end{array}$ & $\begin{array}{c}\text { Rocky Flats } \\
\text { Run } \\
\text { Chloride }(\mathrm{g})\end{array}$ & $\begin{array}{c}\text { NaCl Run } \\
\text { Chloride } \\
\text { Rate }(\mathrm{g} / \mathrm{h})\end{array}$ & $\begin{array}{c}\text { Rocky Flats } \\
\text { Run } \\
\text { Chloride } \\
\text { Rate }(\mathrm{g} / \mathrm{h})\end{array}$ \\
\hline Set \#1 Sampling Duration (h) & 4.7 & 4.3 & & \\
\hline Set \#2 Sampling Duration (h) & 2.0 & 2.3 & & \\
\hline Water + Acid Set \#1 & 11.0 & 11.2 & 2.3 & 2.6 \\
\hline Water + Acid Set \#2 & 16.1 & 14.3 & 8.0 & 6.2 \\
\hline Base* Set \#1 & 0.85 & 0.85 & 0.18 & 0.20 \\
\hline Base Set \#2 & 1.31 & 1.20 & 0.66 & 0.52 \\
\hline
\end{tabular}

* does not include contribution from $\mathrm{Cl}_{2}$

The chloride data for the base impingers indicates that these impingers may have collected $\mathrm{HCl}$ that passed through the water and acid impingers. In general, the acid impingers collected much less chloride than expected, given the amount seen in the base impingers. However, an alternative explanation would be that there really was little $\mathrm{HCl}$ entering the basic impingers and that the chloride found was due to the dissolution of $\mathrm{Cl}_{2}$ to form $\mathrm{HCl}$ and $\mathrm{HClO}$ :

$$
\mathrm{Cl}_{2}+\mathrm{H}_{2} \mathrm{O} \quad \mathrm{H}^{+}+\mathrm{Cl}^{-}+\mathrm{HClO} \quad \text { Eq. } 1
$$

It has been calculated that the amount of sodium thiosulfate used to react with $\mathrm{Cl}_{2}$ in the basic impingers may have been significantly lower than needed. These samples will be rerun to determine if this is true and the results documented in a future report. The data in Table 18 indicate about 3.3 mmol of $\mathrm{Cl}^{-}$from $\mathrm{Cl}_{2}$ were found, but the amount of $\mathrm{Cl}^{-}$from $\mathrm{Cl}_{2}$ may have been as high as 33.4 mmol. With this hypothesis, the amounts of $\mathrm{NaCl}, \mathrm{NaF}, \mathrm{HCl}, \mathrm{HF}$, and $\mathrm{Cl}_{2}$ collected are summarized in Table 21. The several reactions of $\mathrm{NaCl}$ and $\mathrm{KCl}$ are summarized in Figure 12. Either salt can decompose to form $\mathrm{Na}_{2} \mathrm{O}$ in the glass, $\mathrm{NaCl}$ in the offgas particulate, and $\mathrm{HCl}$ or $\mathrm{Cl}_{2}$ in the offgas.

\section{Table 21 Estimated Alkali \& Halide Content of Offgas from the Rocky Flats Run}

\begin{tabular}{|c|c|c|c|c|c|c|}
\hline$(\mathrm{mmol})$ & $\mathrm{NaCl}$ & $\mathrm{KCl}$ & $\mathrm{NaF}$ & $\mathrm{HCl}$ & $\mathrm{HF}$ & $\mathrm{Cl}_{2}$ \\
\hline Particulate & 91.0 & 157. & 1.88 & 4.58 & 1 & \\
\hline Acid Scrubbed & 1.51 & 1.33 & 2 & 401. & 26.7 & \\
\hline Base Scrubbed & & & & & & $33.4^{3}$ \\
\hline
\end{tabular}

$$
\begin{aligned}
\stackrel{\mathrm{NaCl}}{(\text { or } \mathrm{KCl})} & \longrightarrow \mathrm{Na}_{2} \mathrm{O}+\mathrm{Cl} \text { in glass } \\
\longrightarrow & \mathrm{NaCl} \text { in offgas particulate } \\
\stackrel{+\mathrm{H}_{2} \mathrm{O}}{\longrightarrow} & \mathrm{Cl}_{2} \text { in offgas } \\
\longrightarrow & \mathrm{HCl} \text { in offgas }
\end{aligned}
$$

Figure 12 Reactions of $\mathrm{NaCl}$ or $\mathrm{KCl}$ in Melter 
An optical photograph of the offgas particulate collected on a filter from the Rocky Flats Run is shown in Figure 13. The particulate was off-white, very fine textured, and was easily broken up. When the particulate, which was mostly $\mathrm{NaCl}$ and $\mathrm{KCl}$, was recovered by washing with water, the particulate balled-up into dark brown globs. When diluted with excess water, the liquid contained gelatinous brownish solids. For analysis for total metals, the laboratory dissolved these suspended solids with a few drops of concentrated nitric acid.

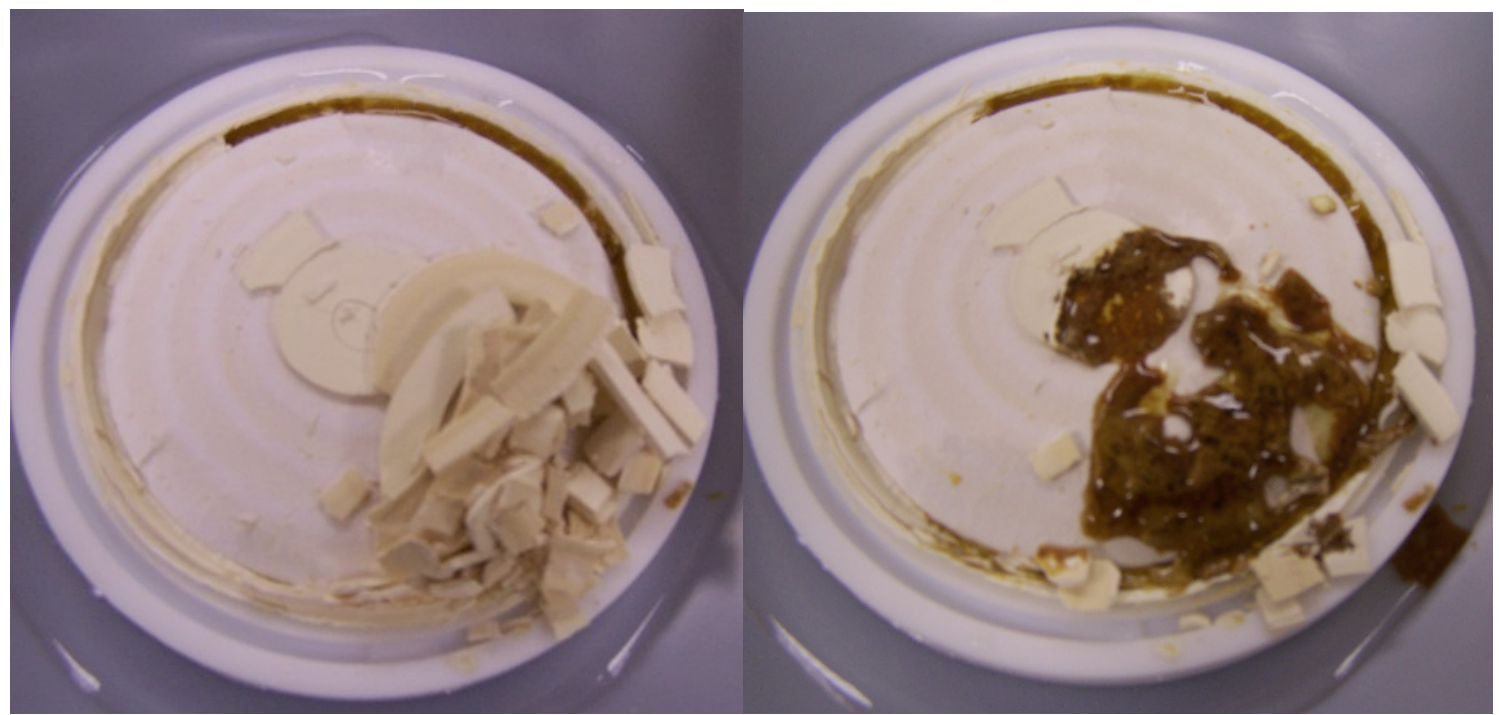

Figure 13 Photographs of Particulate on Filter from the Rocky Flats Run

Offgas particulate collected on the filter from the $\mathrm{NaCl}$ Run was also examined by SEM/EDS. These photographs are shown in Figure 14 through Figure 16. Photo 4 in Figure 14 shows a large particle that is similar to one (spot 3) shown in Figure 16 that was identified by EDS as a glass or frit particle; the EDS spectrum of spot 3 is shown in Figure 17. Photos 8, 9, and 10 show that there were some larger $(\sim 2 \mu \mathrm{m})$ agglomerated particles and cubic particles that suggest entrained $\mathrm{NaCl}$. Almost all of the particles are spherical. As seen in photos 10 and 11, the salt particles were as small as $0.2 \mu \mathrm{m}$ and that they were agglomerated. It appears that a median size may be around $0.5 \mu \mathrm{m}$. Spots 1 and 2 on Photo 2 were also analyzed by EDS, and these results are shown in Figure 17. Spot 1 was a frit or glass particle. Spot 2 was the bulk particulate and was identified as $\mathrm{NaCl}$. 

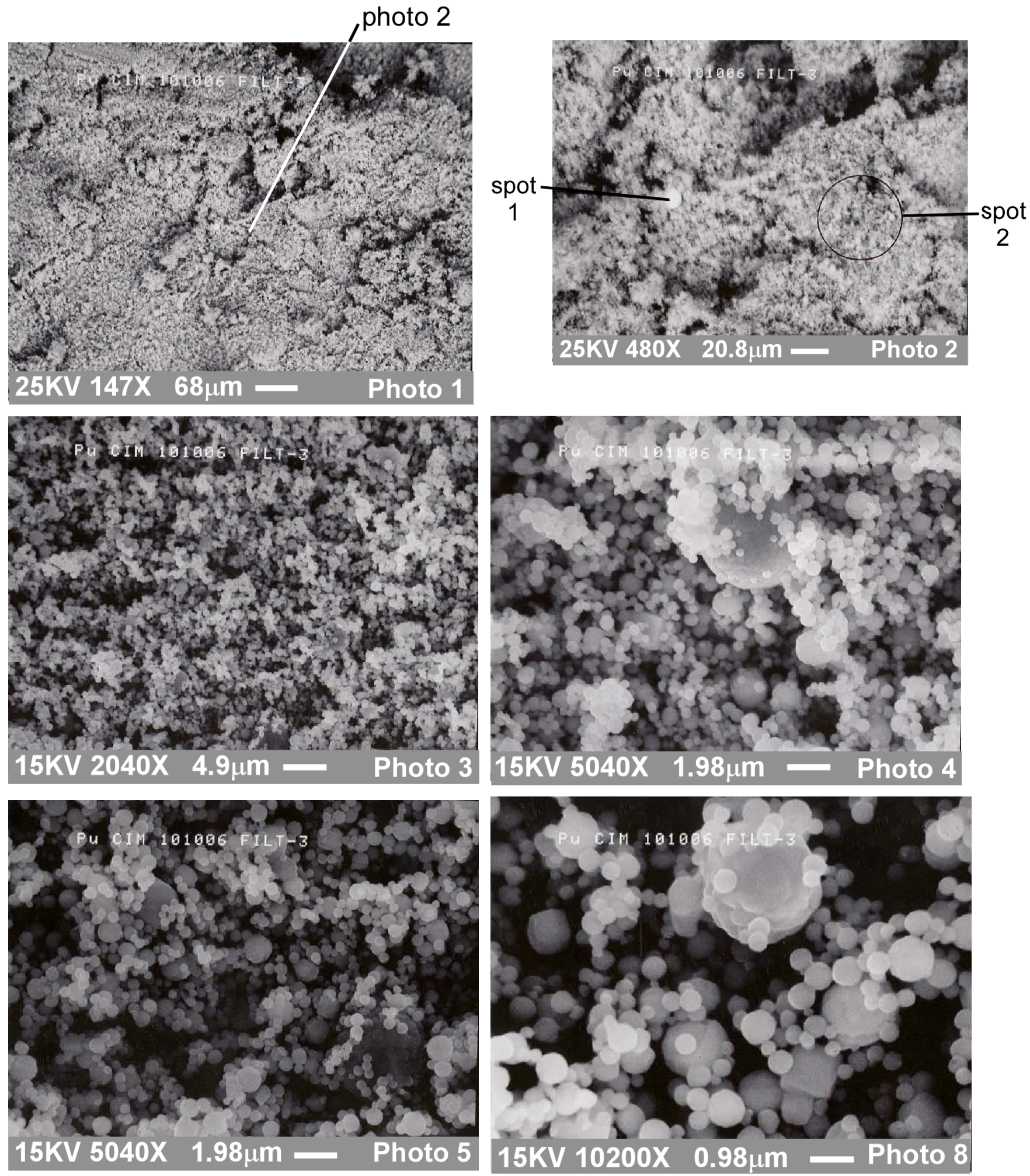

Figure 14 SEM Photographs 1-5, 8 of Offgas Particulate from the NaCl Run 

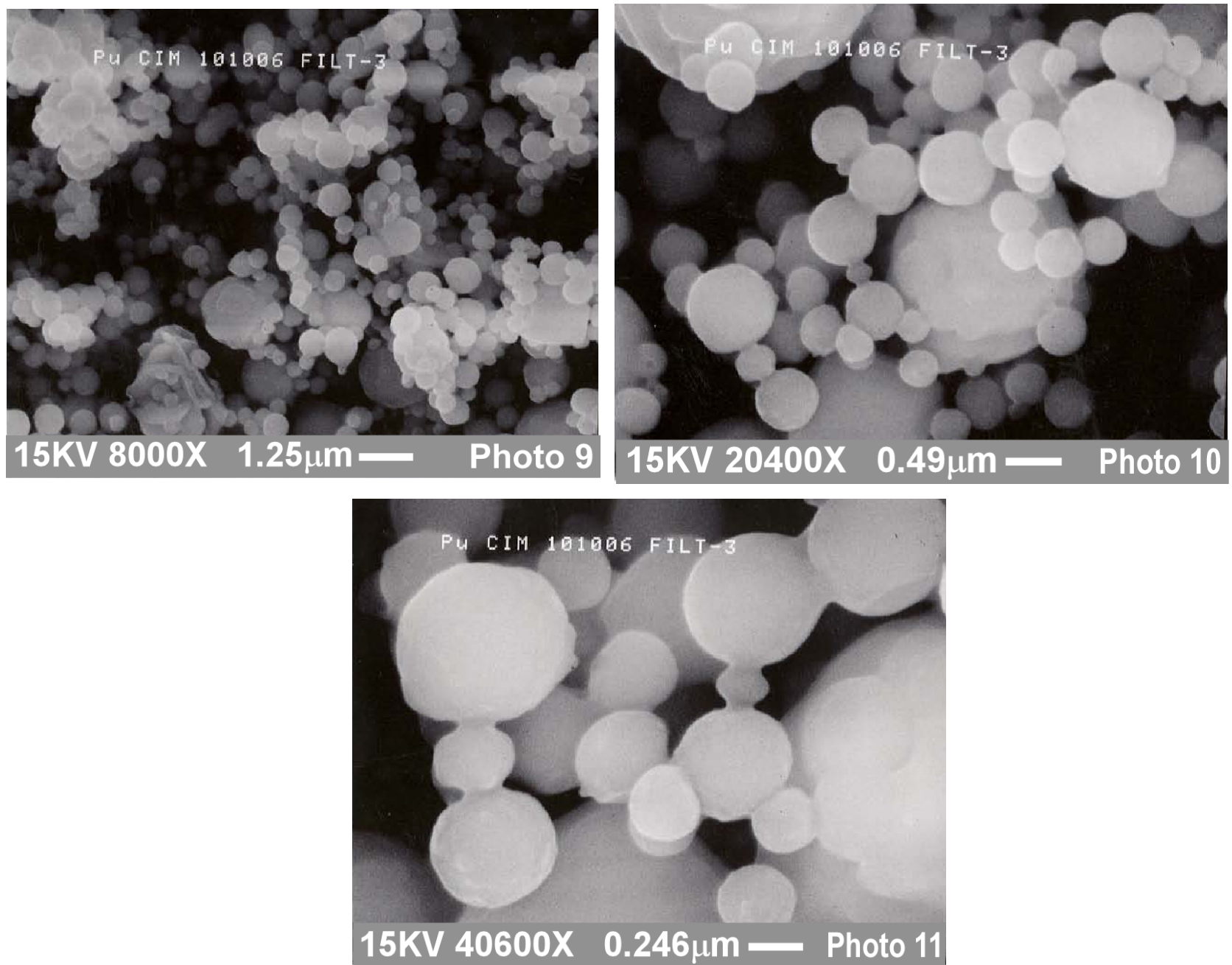

Figure 15 SEM Photographs 9-11 of Offgas Particulate from the NaCl Run
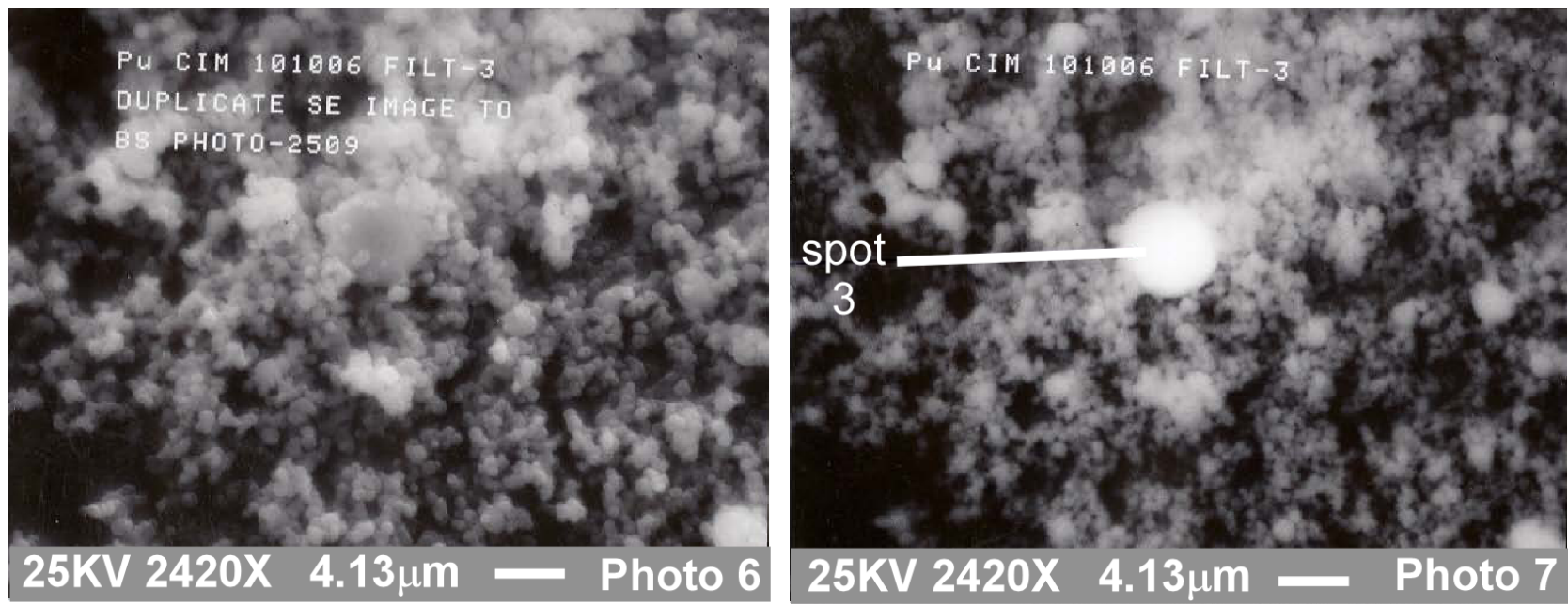

Figure 16 SEM Photographs 6-7 of Offgas Particulate from the NaCl Run 


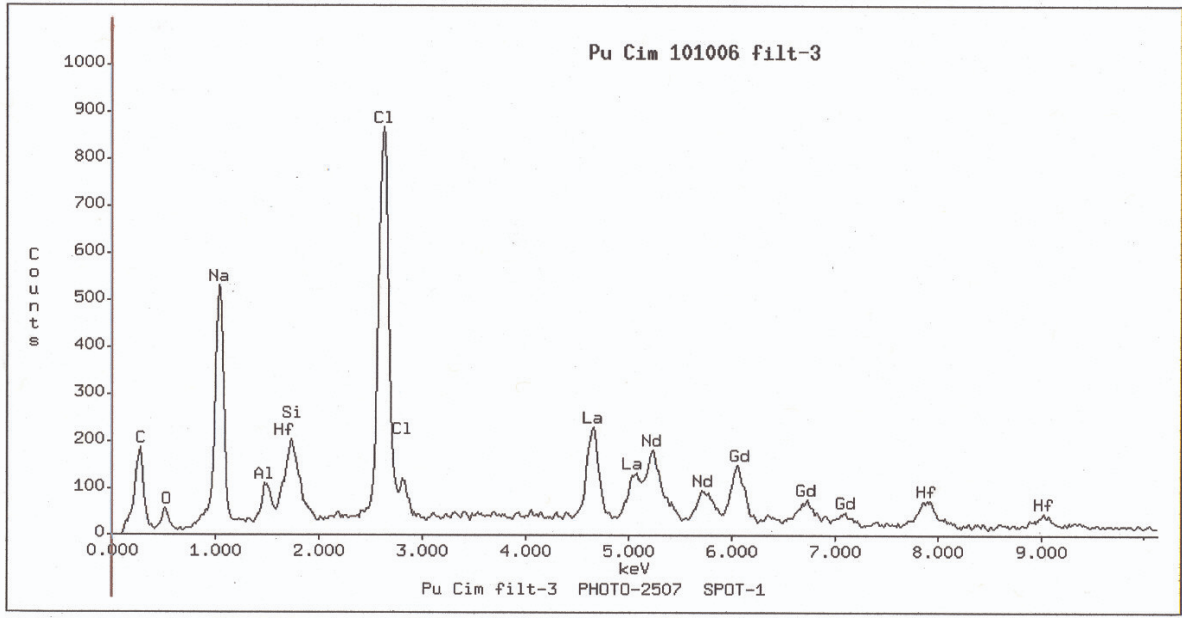

Pu Cim filt-3 PHOTO-2507 SPOT-1

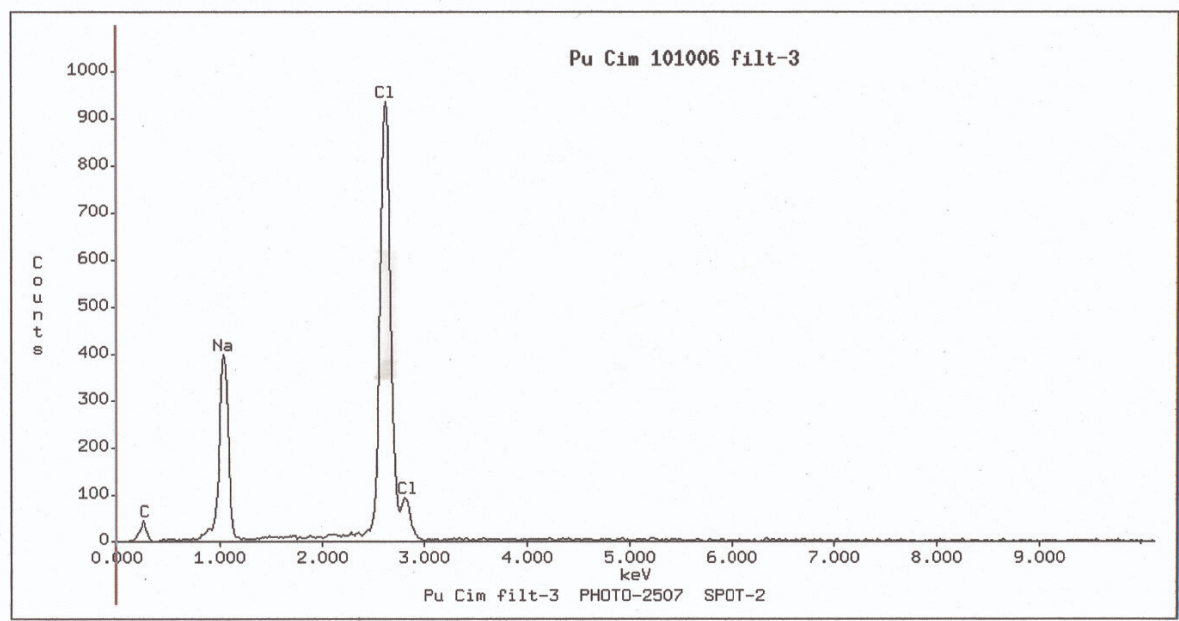

Pu Cim filt-3 PHOTO-2507 SPOT-2

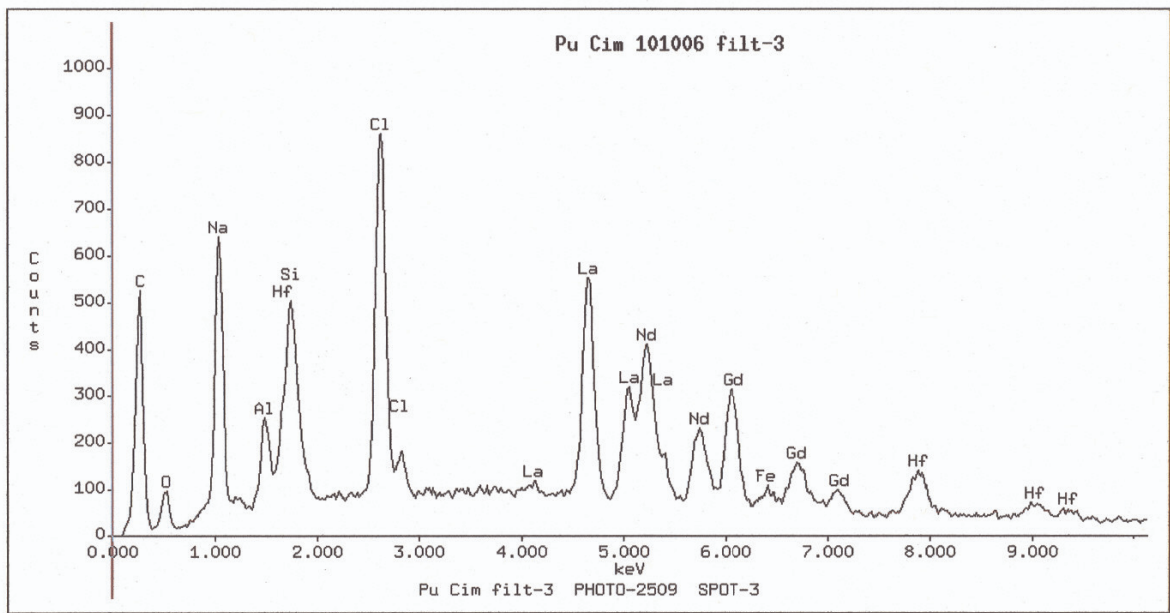

Pu Cim filt-3 PHOTO-2509 SPOT-3

Figure 17 EDS Spectra of Offgas Particulate Samples 
The quartz offgas line was removed after each run and examined. After the $\mathrm{NaCl} \mathrm{Run}$, the inside of the line was coated with a small amount of a brown glassy solid and the top edge was covered with a small amount of gray particulate solids. In the Rocky Flats Run, there was a buildup of reddish brown crystals inside the offgas line and the top edge was again covered with gray particulate solids. A photo of the offgas line from the Rocky Flats Run is shown in Figure 18. The total mass of the crystals recovered was only about $0.05 \mathrm{~g}$.
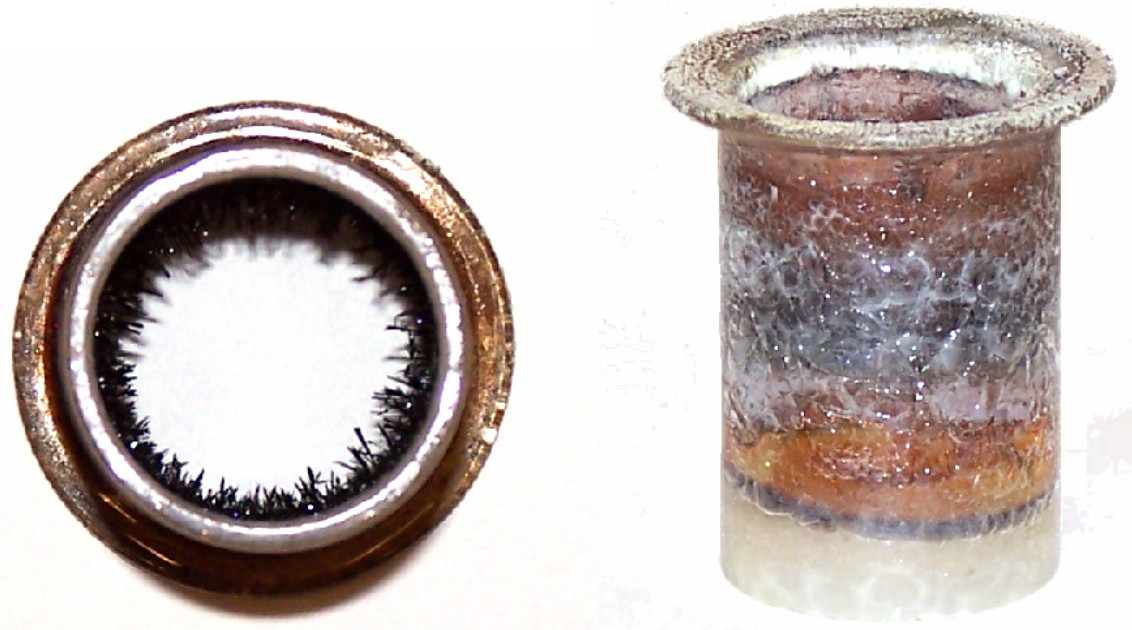

Figure 18 Offgas Line from the Rocky Flats Run Showing Crystalline Buildup and Deposits

The crystalline deposits were analyzed by X-Ray Diffraction (XRD) and X-Ray Fluorescence (XRF) and were also dissolved and analyzed by ICP-AES for elements. The quartz offgas line minus the crystals removed was analyzed by ICP-AES after dissolving much, but not all of the solids deposits in aqua regia. The XRD of the crystals is shown in Figure 19. The crystals were identified as a mixture of $\mathrm{KCl}, \mathrm{NiO}$, and what appears to be a solid solution of metal borates with a ludwigite-like structure such as bonaccordite $\left(\mathrm{Ni}_{2}\right)^{+4}(\mathrm{Fe})^{+3}\left(\mathrm{BO}_{5}\right)^{-7}$. Bonaccordite is a reddish brown crystal.

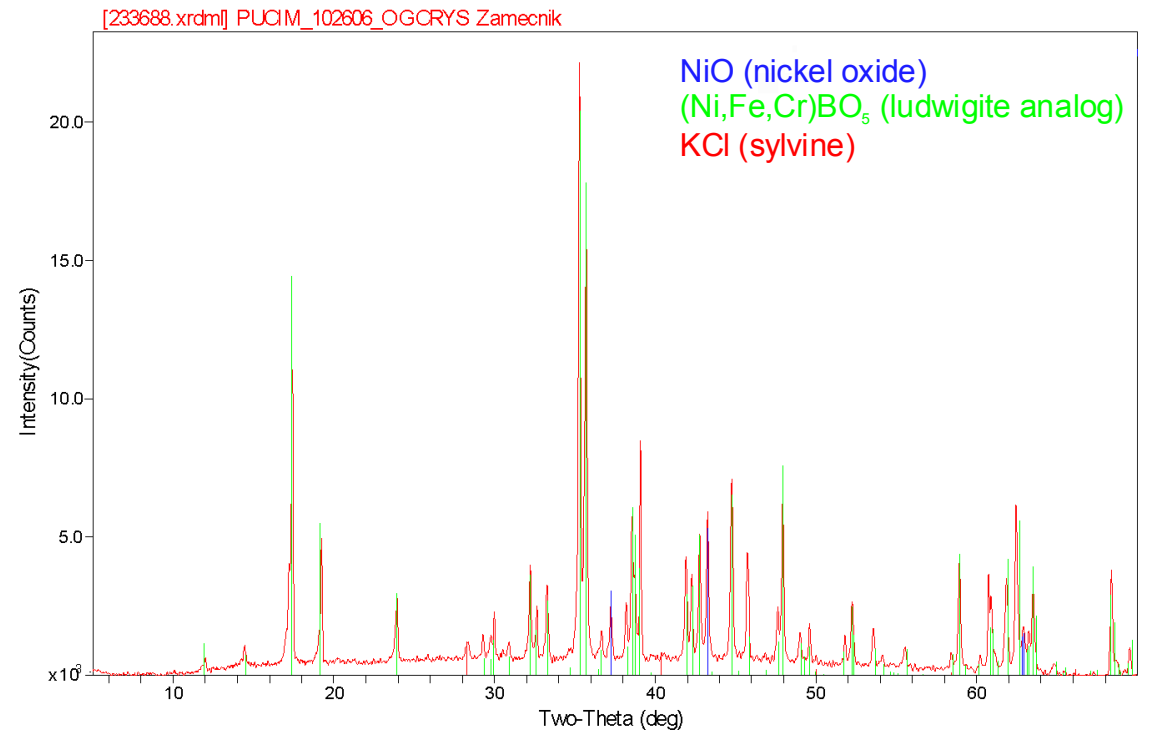

Figure 19 XRD Spectrum of Offgas Crystal Deposits 
The composition of the crystal deposits and the deposits dissolved from the offgas line are shown in Table 22. In both the crystals and the deposits, boron predominated on a molar basis by 2:1 over the combined $\mathrm{Na}+\mathrm{K}$, which were the next most abundant. Because $\mathrm{KCl}$ was identified by XRD it is also likely that $\mathrm{NaCl}$ was present. To account for the significant amount of boron found, the presence of alkali borates $\left(\mathrm{NaB}_{3} \mathrm{O}_{5}, \mathrm{NaBO}_{2}, \mathrm{Na}_{2} \mathrm{~B}_{4} \mathrm{O}_{7}\right)$ is also likely. Iron and nickel were the next most abundant, in accord with the presence of bonaccordite. The transition metals Mo and $\mathrm{W}$ and also Sr were next in abundance, followed by $\mathrm{Cr}$ and $\mathrm{Cu}$. Small amounts of the lanthanides, Hf, Al, and Si were also found. These would be accounted for by entrainment of glass or frit. Si will also be present from dissolution of some of the quartz.

Table 22 Composition of Offgas Crystals and Offgas Deposits from the Rocky Flats Run

\begin{tabular}{|c|c|c|c|c|}
\hline \multirow[b]{2}{*}{ Element } & \multicolumn{2}{|c|}{-----Crystals------- } & \multicolumn{2}{|c|}{------Deposits------ } \\
\hline & $\mathrm{mg} / \mathrm{kg}$ & $\begin{array}{c}\mathrm{mmol} / \mathrm{kg} \\
\text { crystals }\end{array}$ & $\mathrm{mg} / \mathrm{kg}$ & $\begin{array}{c}\mathrm{mmol} / \mathrm{kg} \\
\text { offgas line }\end{array}$ \\
\hline $\mathrm{Al}$ & 820 & 30.4 & 1055 & 39.1 \\
\hline B & 44900 & 4153 & 119000 & 11007 \\
\hline $\mathrm{Ca}$ & $<10$ & NA & $<10$ & NA \\
\hline $\mathrm{Cr}$ & 440 & 8.46 & 1650 & 31.7 \\
\hline $\mathrm{Cu}$ & 330 & 5.19 & 1445 & 22.7 \\
\hline $\mathrm{Fe}$ & 3525 & 63.1 & 11600 & 208 \\
\hline Gd & 220 & 1.40 & 136 & 0.87 \\
\hline Hf & 103 & 0.57 & 59 & 0.33 \\
\hline $\mathbf{K}$ & 25450 & 651 & 189000 & 4834 \\
\hline $\mathrm{La}$ & 220 & 1.58 & 208 & 1.49 \\
\hline $\mathrm{Mg}$ & $<10$ & NA & 152 & 6.25 \\
\hline Mo & 1490 & 15.5 & 2095 & 21.8 \\
\hline $\mathbf{N a}$ & 38900 & 1692 & 129000 & 5611 \\
\hline $\mathrm{Nd}$ & 368 & 2.55 & 180 & 1.25 \\
\hline$N i$ & 3075 & 52.4 & 8460 & 144 \\
\hline $\mathrm{P}$ & $<1000$ & NA & $<1000$ & NA \\
\hline $\mathrm{Pb}$ & $<10$ & NA & $<10$ & NA \\
\hline $\mathrm{S}$ & $<500$ & NA & $<500$ & NA \\
\hline $\mathrm{Si}^{*}$ & 3355 & 119 & 22300 & 794 \\
\hline $\mathrm{Sr}$ & 2140 & 24.4 & 2525 & 28.8 \\
\hline W & 2175 & 11.8 & 829 & 4.51 \\
\hline $\mathrm{Zr}$ & $<10$ & NA & 449 & 4.92 \\
\hline
\end{tabular}

bold: most abundant italic: most abundant metals

shaded: frit components $\quad *$ Si present in quartz offgas line

\subsection{Glass Composition}

The predicted and measured glass compositions for the $\mathrm{NaCl}$ and Rocky Flats Runs are shown in Table 23. The table gives the composition predicted from subtracting the measured offgas species from the feed. Elements that deviated more than $25 \%$ from the predicted composition are shown in bold in the \% Difference column. 
For the $\mathrm{NaCl}$ Run, all species except $\mathrm{Cl}$ were within $25 \%$ of the predicted concentrations. The measured chloride in the glass was lower than predicted because the measured total chloride in the offgas was probably lower than the actual amount in the offgas. Small amounts of $\mathrm{Ca}, \mathrm{Cu}, \mathrm{Fe}$, and $\mathrm{Zr}$ were found in the the $\mathrm{NaCl}$ Run glass even though none was intentionally added in the Frit $\mathrm{X}, \mathrm{HfO}_{2}$, or impurity $\mathrm{NaCl}$. In the Rocky Flats Run, the $\mathrm{Ca}, \mathrm{Cu}, \mathrm{Fe}$, and $\mathrm{Zr}$ were again higher than the amounts added to the feed; in fact, the $\mathrm{Ca}, \mathrm{Cu}$ and $\mathrm{Fe}$ present as impurities were higher than the intended amount to be added. The source of $\mathrm{Zr}$ is most likely the $\mathrm{HfO}_{2}$ used as the surrogate for $\mathrm{PuO}_{2}$ and for the frit; $\mathrm{ZrO}_{2}$ is an impurity at up to $1.5 \mathrm{wt} \%$ in $\mathrm{HfO}_{2}$. As mentioned previously, the source of $\mathrm{Fe}$ is probably processing in ferrous metal equipment, while the $\mathrm{Cu}$ could have come from frit screening on brass sieves. Brass contains both $\mathrm{Cu}$ and $\mathrm{Zn}$, but $\mathrm{Zn}$ would not be found in the glass due to its volatility. Reanalysis of the Frit $\mathrm{X}$ for impurities is pending.

The $\mathrm{Na}$ was also higher than predicted, but only by $27.5 \%$. Na was definitely found in the offgas as $\mathrm{NaCl}$, so the total amount of $\mathrm{Na}$ added may have also been higher than intended. Both $\mathrm{Ni}$ and $\mathrm{Cr}$ were low; both were found to be volatile and were found in both the offgas particulate samples and in offgas line deposits. The amounts of each of these in the offgas line deposits were not accounted for in the material balance; these deposits may account for the missing $\mathrm{Cr}$ and $\mathrm{Ni}$. The balance on chloride was good, with both the measured and predicted concentration in the glass being about 0.4 wt $\%$.

Fluoride and chloride were measured in the glass using a sodium peroxide/sodium hydroxide fusion with water uptake that does not dissolve all of the fused product. It appears that fluoride does not dissolve in the water uptake. For test glasses made with $\mathrm{CaF}_{2}$, the calcium was present at a molar ratio of $\mathrm{Ca}: \mathrm{F}$ of 1:2 and much less than expected fluoride was found in the glass. Analysis of glasses with fluoride in significant excess over calcium give slightly low fluoride measurements. If the fluoride is bound to the calcium in the fusion, the water uptake is not likely to dissolve it, resulting in low measurements of fluoride. Analytical method development will be required to accurately quantify fluoride in the presence of excess calcium. 
Table 23 Predicted and Measured Compositions of Glasses Produced from Runs the NaCl and Rocky Flats Runs.

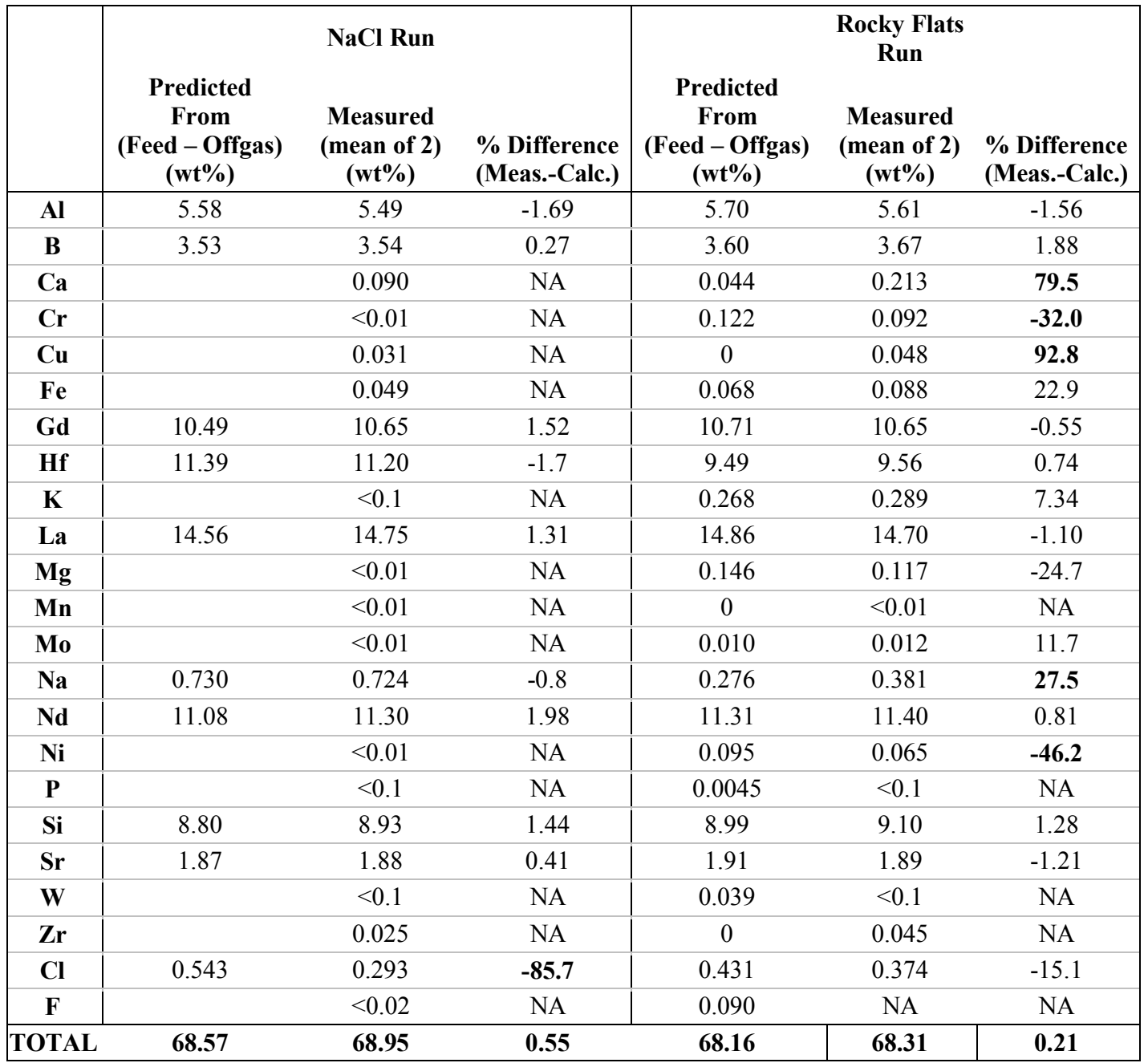


Table 24 shows the predicted composition of the Rocky Flats Run glass assuming incorporation into the glass of 1) all impurities; 2) only the cation (metal impurities) plus phosphorus; 3) no impurities; and 4) impurities predicted by the material balance (feed - offgas); these values are compared to the measured values. This comparison is presented on both elemental and oxide bases.

Table 24 Elemental and Oxide Concentrations Predicted and Measured for Glass from the Rocky Flats Run

\begin{tabular}{|c|c|c|c|c|c|c|c|c|c|c|c|}
\hline Element & $\begin{array}{c}\text { All } \\
\text { Impurities } \\
(\mathbf{w t} \%)\end{array}$ & $\begin{array}{c}\text { Cation } \\
\text { Impurities } \\
+\mathbf{P} \\
(\mathbf{w t} \%) \\
\end{array}$ & $\begin{array}{c}\text { No } \\
\text { Impurities } \\
(\mathbf{w t} \%) \\
\end{array}$ & $\begin{array}{l}\text { Feed - } \\
\text { Offgas } \\
(w t \%)\end{array}$ & $\begin{array}{c}\text { Measured } \\
\text { Mean } \\
(w t \%)\end{array}$ & Oxide & $\begin{array}{c}\text { All } \\
\text { Impurities } \\
(\mathbf{w t} \%)\end{array}$ & $\begin{array}{c}\text { Cation } \\
\text { Impurities } \\
+\mathbf{P} \\
(\mathbf{w t} \%) \\
\end{array}$ & $\begin{array}{c}\text { No } \\
\text { Impurities } \\
(\mathbf{w t} \%) \\
\end{array}$ & $\begin{array}{l}\text { Feed - } \\
\text { Offgas } \\
(w t \%)\end{array}$ & $\begin{array}{c}\text { Measured } \\
\text { Mean } \\
(\mathbf{w t} \%)\end{array}$ \\
\hline Al & 5.63 & 5.70 & 5.81 & 5.70 & 5.61 & $\mathbf{A l}_{2} \mathbf{O}_{3}$ & 10.63 & 10.78 & 10.99 & 10.77 & 10.60 \\
\hline B & 3.56 & 3.61 & 3.68 & 3.60 & 3.67 & $\mathbf{B}_{2} \mathbf{O}_{3}$ & 11.47 & 11.63 & 11.85 & 11.60 & 11.83 \\
\hline $\mathrm{Ca}$ & 0.043 & 0.044 & 0 & 0.044 & 0.213 & $\mathrm{CaO}$ & 0.060 & 0.061 & 0 & 0.061 & 0.298 \\
\hline $\mathrm{Cr}$ & 0.125 & 0.126 & 0 & 0.122 & 0.092 & $\mathrm{Cr}_{2} \mathrm{O}_{3}$ & 0.182 & 0.184 & 0 & 0.178 & 0.135 \\
\hline $\mathrm{Cu}$ & 0.008 & 0.008 & 0 & 0.003 & 0.048 & $\mathrm{CuO}$ & 0.010 & 0.010 & 0 & 0.004 & 0.060 \\
\hline $\mathbf{F e}$ & 0.070 & 0.071 & 0 & 0.068 & 0.088 & $\mathrm{Fe}_{2} \mathrm{O}_{3}$ & 0.099 & 0.101 & 0 & 0.097 & 0.126 \\
\hline Gd & 10.57 & 10.72 & 10.92 & 10.71 & 10.65 & $\mathbf{G d}_{2} \mathrm{O}_{3}$ & 12.18 & 12.35 & 12.59 & 12.34 & 12.28 \\
\hline Hf & 9.38 & 9.51 & 9.69 & 9.49 & 9.56 & $\mathrm{HfO}_{2}$ & 11.06 & 11.21 & 11.43 & 11.19 & 11.27 \\
\hline $\mathbf{K}$ & 0.471 & 0.477 & 0 & 0.268 & 0.289 & $\mathbf{K}_{2} \mathbf{O}$ & 0.567 & 0.575 & 0 & 0.323 & 0.348 \\
\hline La & 14.67 & 14.87 & 15.16 & 14.86 & 14.70 & $\mathrm{La}_{2} \mathrm{O}_{3}$ & 17.21 & 17.44 & 17.78 & 17.43 & 17.24 \\
\hline Mg & 0.144 & 0.146 & 0 & 0.146 & 0.117 & MgO & 0.239 & 0.243 & 0 & 0.242 & 0.194 \\
\hline Mo & 0.014 & 0.014 & 0 & 0.010 & 0.012 & $\mathrm{MoO}_{3}$ & 0.020 & 0.021 & 0 & 0.016 & 0.018 \\
\hline $\mathrm{Na}$ & 0.345 & 0.350 & 0 & 0.276 & 0.381 & $\mathrm{Na}_{2} \mathrm{O}$ & 0.465 & 0.472 & 0 & 0.373 & 0.514 \\
\hline Nd & 11.16 & 11.32 & 11.53 & 11.31 & 11.40 & $\mathbf{N d}_{2} \mathbf{O}_{3}$ & 13.02 & 13.20 & 13.45 & 13.19 & 13.30 \\
\hline $\mathbf{N i}$ & 0.117 & 0.119 & 0 & 0.095 & 0.065 & $\mathrm{NiO}$ & 0.149 & 0.151 & 0 & 0.121 & 0.082 \\
\hline $\mathbf{P}$ & 0.004 & 0.004 & 0 & 0.004 & $<0.1$ & $\mathbf{P}_{2} \mathrm{O}_{5}$ & 0.010 & 0.010 & 0 & 0.010 & $<$ \\
\hline $\mathbf{S i}$ & 8.87 & 8.99 & 9.17 & 8.99 & 9.10 & $\mathrm{SiO}_{2}$ & 18.98 & 19.24 & 19.61 & 19.22 & 19.47 \\
\hline $\mathrm{Sr}$ & 1.89 & 1.91 & 1.95 & 1.91 & 1.89 & SrO & 2.23 & 2.26 & 2.30 & 2.26 & 2.23 \\
\hline $\mathbf{W}$ & 0.039 & 0.040 & 0 & 0.039 & $<0.1$ & $\mathrm{WO}_{3}$ & 0.050 & 0.050 & 0 & 0.050 & $<$ \\
\hline $\mathrm{Zr}$ & 0 & 0 & 0 & 0 & 0.045 & $\mathrm{ZrO}_{2}$ & 0 & 0 & 0 & 0 & 0.061 \\
\hline $\mathrm{Cl}$ & 1.25 & 0 & 0 & 0.431 & 0.374 & Cl & 1.25 & 0 & 0 & 0.431 & 0.374 \\
\hline $\mathbf{F}$ & 0.107 & 0 & 0 & 0.090 & NA & $\mathbf{F}$ & 0.107 & 0 & 0 & 0.090 & $<$ \\
\hline TOTAL & 68.47 & 68.04 & 67.92 & 68.16 & 68.31 & TOTAL & 100 & 100 & 100 & 100 & 100.43 \\
\hline
\end{tabular}

$<$ alone indicates element measured value was below detection limit 
The glass compositions on an elemental and an oxide basis for the $\mathrm{NaCl}$ and Rocky Flats Runs are compared in Table 25 . The oxide totals for both were very close to the expected $100 \%$. The Hf content of the $\mathrm{NaCl}$ Run glass was higher than the Rocky Flats Run glass as expected due to a higher target value. XRD measurements on the glass from the $\mathrm{NaCl}$ Run showed a small amount of crystalline $\mathrm{HfO}_{2}$ present.

Table 25 Measured Compositions of Glass from the NaCl and Rocky Flats Runs

\begin{tabular}{|c|c|c|c|c|c|c|c|c|c|}
\hline Element & Oxide & $\begin{array}{c}\text { Sample 1 } \\
(\mathrm{wt} \%)\end{array}$ & $\begin{array}{c}\text { NaCl Run } \\
\text { Sample } 2 \\
(w t \%)\end{array}$ & Mean & $\begin{array}{c}\text { Oxides } \\
(w t \%)\end{array}$ & $\begin{array}{c}\text { Sample } 1 \\
(\mathrm{wt} \%)\end{array}$ & $\begin{array}{c}\text { Rocky } \\
\text { Flats Run } \\
\text { Sample } 2 \\
(w t \%) \\
\end{array}$ & Mean & $\begin{array}{l}\text { Oxides } \\
(\mathbf{w t} \%)\end{array}$ \\
\hline Al & $\mathbf{A l}_{2} \mathbf{O}_{3}$ & 5.52 & 5.47 & 5.49 & 10.37 & 5.56 & 5.67 & 5.61 & 10.60 \\
\hline B & $\mathbf{B}_{2} \mathbf{O}_{3}$ & 3.54 & 3.54 & 3.54 & 11.40 & 3.64 & 3.71 & 3.67 & 11.83 \\
\hline $\mathbf{C a}$ & $\mathrm{CaO}$ & 0.103 & 0.078 & 0.090 & 0.126 & 0.195 & 0.231 & 0.213 & 0.298 \\
\hline $\mathrm{Cr}$ & $\mathrm{Cr}_{2} \mathrm{O}_{3}$ & $<0.01$ & $<0.01$ & $<0.01$ & 0 & 0.093 & 0.092 & 0.092 & 0.135 \\
\hline $\mathrm{Cu}$ & $\mathrm{CuO}$ & 0.031 & 0.032 & 0.031 & 0.039 & 0.056 & 0.040 & 0.048 & 0.060 \\
\hline $\mathbf{F e}$ & $\mathrm{Fe}_{2} \mathrm{O}_{3}$ & 0.052 & 0.047 & 0.049 & 0.070 & 0.086 & 0.091 & 0.088 & 0.126 \\
\hline Gd & $\mathrm{Gd}_{2} \mathrm{O}_{3}$ & 10.65 & 10.65 & 10.65 & 12.28 & 10.80 & 10.50 & 10.65 & 12.28 \\
\hline Hf & $\mathrm{HfO}_{2}$ & 11.10 & 11.30 & 11.20 & 13.21 & 9.56 & 9.56 & 9.56 & 11.30 \\
\hline $\mathbf{K}$ & $\mathrm{K}_{2} \mathrm{O}$ & $<0.1$ & $<0.1$ & $<0.1$ & 0 & 0.282 & 0.296 & 0.289 & 0.348 \\
\hline La & $\mathrm{La}_{2} \mathrm{O}_{3}$ & 14.75 & 14.75 & 14.75 & 17.30 & 14.95 & 14.45 & 14.70 & 17.24 \\
\hline Mg & MgO & $<0.01$ & $<0.01$ & $<0.01$ & 0 & 0.110 & 0.125 & 0.117 & 0.194 \\
\hline Mo & $\mathrm{MoO}_{3}$ & $<0.01$ & $<0.01$ & $<0.01$ & 0 & 0.012 & 0.012 & 0.012 & 0.018 \\
\hline $\mathbf{N a}$ & $\mathrm{Na}_{2} \mathrm{O}$ & 0.723 & 0.725 & 0.724 & 0.976 & 0.427 & 0.336 & 0.381 & 0.514 \\
\hline Nd & $\mathrm{Nd}_{2} \mathrm{O}_{3}$ & 11.35 & 11.25 & 11.30 & 13.18 & 11.35 & 11.45 & 11.40 & 13.30 \\
\hline $\mathbf{N i}$ & $\mathrm{NiO}$ & $<0.01$ & $<0.01$ & $<0.01$ & 0 & 0.060 & 0.070 & 0.065 & 0.082 \\
\hline $\mathbf{P}$ & $\mathbf{P}_{2} \mathbf{O}_{5}$ & $<0.1$ & $<0.1$ & $<0.1$ & 0 & $<0.1$ & $<0.1$ & $<0.1$ & 0 \\
\hline $\mathbf{S i}$ & $\mathrm{SiO}_{2}$ & 8.96 & 8.90 & 8.93 & 19.10 & 9.03 & 9.18 & 9.10 & 19.47 \\
\hline $\mathrm{Sr}$ & SrO & 1.88 & 1.88 & 1.88 & 2.22 & 1.92 & 1.86 & 1.89 & 2.23 \\
\hline $\mathbf{W}$ & $\mathrm{WO}_{3}$ & $<0.1$ & $<0.1$ & $<0.1$ & 0 & $<0.1$ & $<0.1$ & $<0.1$ & 0 \\
\hline $\mathbf{Z r}$ & $\mathrm{ZrO}_{2}$ & 0.025 & 0.025 & 0.025 & 0.034 & 0.069 & 0.021 & 0.045 & 0.061 \\
\hline CI & Cl & 0.294 & 0.291 & 0.293 & 0.293 & 0.370 & 0.379 & 0.374 & 0.374 \\
\hline $\mathbf{F} *$ & $\mathbf{F}$ & $<0.02$ & $<0.02$ & $<0.02$ & 0 & $<0.02$ & $<0.02$ & NA & 0 \\
\hline & TOTAL & & & & 100.6 & & & & 100.4 \\
\hline
\end{tabular}

* measured; based on material balance (feed $\&$ offgas), estimate $\mathrm{F}$ in glass to be $\sim 0.09 \mathrm{wt} \%$

\subsection{SUMMARY \& CONCLUSIONS}

The following summarizes the results of these tests and conclusions that can be drawn.

- Approximately $72 \%$ of $\mathrm{NaCl}$ added as an impurity at $2.5 \mathrm{wt} \%$ in the feed was emitted into the offgas as particulate $\mathrm{NaCl}, \mathrm{HCl}$, or $\mathrm{Cl}_{2}$.

- About $54-61 \%$ of an impurity mixture added at $3.16 \mathrm{wt} \%$ in the feed was emitted into the offgas as particulate or vapor.

- Particulate generated was mostly $\mathrm{NaCl}$ and $\mathrm{KCl}$ (these were the major impurities added).

- Offgas vapors consisted of $\mathrm{HCl}, \mathrm{Cl}_{2}$, and $\mathrm{HF}$. $\mathrm{HCl}$ and $\mathrm{Cl}_{2}$ could not be totally distinguished.

- Feed entrainment as indicated by frit elements in the offgas particulate was $<0.03 \mathrm{wt} \%$ except for $\mathrm{Sr}(<0.1 \mathrm{wt} \%), \mathrm{B}(0.13-0.16 \mathrm{wt} \%)$, and $\mathrm{Hf}(0.16 \mathrm{wt} \%)$. Sr and B are the most volatile components of the frit. $\mathrm{HfO}_{2}$ surrogate may have been entrained. 
- About $65 \%$ of the $\mathrm{Cl}, 20-25 \%$ of the $\mathrm{Na}$, and $45 \%$ of the $\mathrm{K}$ fed were evolved into the offgas system.

- The elements $\mathrm{Cu}, \mathrm{Mo}, \mathrm{Ni}, \mathrm{Fe}$, and $\mathrm{Cr}$ were also volatile $(60,25,20,4,3 \%$, respectively).

- Crystalline deposits found in the offgas line consisted of $\mathrm{KCl}, \mathrm{NiO}$, and $\mathrm{Ni}_{2} \mathrm{FeBO}_{5}$ and similar compounds with $\mathrm{Cr}$.

- About $83 \%$ of $\mathrm{F}$ fed, or $0.09 \mathrm{wt} \%$ in glass, was retained in the glass (by material balance; $\mathrm{F}$ at this concentration could not be quantified directly).

- Chloride $(\mathrm{Cl})$ in the glass ranged from $0.29-0.37 \mathrm{wt} \%$.

- Particulate consisted of water insoluble $\mathrm{Al}, \mathrm{Fe}, \mathrm{Mo}, \mathrm{W}, \mathrm{PO}_{4}^{-3}$, partially soluble $\mathrm{F}, \mathrm{Cr}$, $\mathrm{K}$, and soluble $\mathrm{Cl}, \mathrm{B}, \mathrm{Cu}, \mathrm{Ni}, \mathrm{Na}, \mathrm{Sr}$.

- Approximately $99.2 \mathrm{wt} \%$ of volatilized species (excluding $\mathrm{HCl}, \mathrm{Cl}_{2}, \mathrm{HF}$ ) were collected on the nominal $0.3 \mu \mathrm{m}$ filter.

- Visible particulate was evolved 1) from the impurity mixture at $\left.680{ }^{\circ} \mathrm{C}, 2\right)$ from $\mathrm{NaCl}$ only at $980{ }^{\circ} \mathrm{C}$, and 3 ) from the remelt of the impurity mixture at $1170{ }^{\circ} \mathrm{C}$ (indicating salt impurities were trapped within the glass matrix).

- Particulate emission rates were $0.8-2.6 \mathrm{~g} / \mathrm{kg}$ glass $/ \mathrm{h}$.

- Particulate generated was mostly spherical salt particles as small as $0.2 \mu \mathrm{m}$, with an approximate median size of about $0.5 \mu \mathrm{m}$. Larger agglomerates may have also been present.

- Particulate particles stick together by forming bridges between them when caught on the filter.

- $\mathrm{NaCl}$ forms $\mathrm{Na}_{2} \mathrm{O}$ and $\mathrm{Cl}$ in the glass, $\mathrm{NaCl}$ particulate, and $\mathrm{HCl}+\mathrm{Cl}_{2}$ gas. $(\mathrm{KCl}$ behaves similarly.)

- Fluorides are retained in the glass (F) and also emitted to the offgas as salts (e.g., NaF, KF) and HF gas.

- Melter runs with LaBS Frit X exhibited consistent behavior allowing repeatable temperature profiles for offgas testing.

- Use of batch chemicals including boric acid for frit production required additional soak time at low power to avoid bed expansion.

- Pouring behavior was consistent and yielded complete discharge of glass from the melter while leaving a sufficient plug in the drain tube for the following run.

\subsection{RECOMMENDATIONS}

1. Measure the aerodynamic particle size distribution of the offgas particulate with a cascade impactor.

2. Perform offgas characterization tests with all compounds that could be washed out with water removed (e.g., $\mathrm{NaCl}, \mathrm{KCl})$.

3. Test salt feed concentrations near their apparent "solubility limit" in the glass (e.g. $\sim 0.3 \mathrm{wt} \% \mathrm{Cl}$ ) 
4. Test simple impingement devices for collection of particulate salts from the offgas.

5. Determine if the bubbler is required for thorough mixing to be achieved in the CIM.

6. Measure the particle size distribution of the $\mathrm{HfO}_{2}$ used.

7. Add additional thiosulfate reductant and repeat measurements of chloride in offgas samples where incomplete conversion of $\mathrm{Cl}_{2}$ to $\mathrm{Cl}^{-}$is suspected.

\subsection{REFERENCES}

1 T.M. Jones, J.C. Marra, D.M. Immel and B.Z. Meers, Glass Macrocracking Determination in Prototypic Canisters Containing Lanthanide Borosilicate Glass, WSRC-TR-2006-00015, January 2006.

2 J.C. Marra, D.K. Peeler, and C.M. Jantzen, Development of an Alternative Glass Formulation for Vitrification of Excess Plutonium, WSRC-TR-2006-00031, January 2006.

3 T.M. Jones, Americium-Curium Stabilization - 5" Cylindrical Induction Melter System Design Basis (U), SRT-AMC-99-0001, January 1999.

4 T.M. Jones, D.H. Miller, J.W. Duval, R.F. Schumacher and J.M. Marra, ITS Research and Development - ACTL CIM5 Operation Laboratory Notebook, WSRC-NB-2001-00086, July 2005 - October 2006.

5 T.M. Jones and D.H. Miller, Pu Immobilization Program CIM Testing Laboratory Notebook, WSRC-NB-2006-00144, November 2006.

6 J.R. Zamecnik, S. Jung, Analysis of Characterization Data for Surrogate Plutonium Glasses with Impurities, M\&O-PUD-2006-00067, Rev. 0.

$7 \quad$ D.T. Herman, Trip Report from Travel to Union Process, M\&O-PUD-2006-00094.

8 (EPA) Method 26 - Determination of Hydrogen Halide and Halogen Emissions from Stationary Sources Non-Isokinetic Method, 40 CFR 60 Appendix A.

9 Job Hazards Analysis, SRNL-PSE-2006-00232.

10 Environmental Evaluation Checklist, TC-W-2006-104.

11 J.M. Tingey and S.A. Jones, Chemical and Radiochemical Composition of Thermally Stabilized Plutonium Oxide from the Plutonium Finishing Plant Considered as Alternate Feedstock for the Mixed Oxide Fuel Fabrication Facility, PNNL-15421, July 2005.

12 J.R. Zamecnik and V.J. Williams, Plutonium Vitrification Testing Laboratory Notebook, WSRC-NB-2006-00030, October - November 2006. 


\subsection{APPENDIX}

\section{Table $26 \quad 9 / 05 / 06$ Run Data (1/10 ${ }^{\text {th }}$ Data Shown)}

\begin{tabular}{|c|c|c|c|c|c|c|c|c|c|c|c|c|c|c|c|c|}
\hline Minutes & $\begin{array}{l}\text { Glass Temp } \\
\text { deg C }\end{array}$ & $\begin{array}{l}\text { Melter Top T2 } \\
\operatorname{deg} \text { C }\end{array}$ & $\begin{array}{l}\text { Melter Midpoint T3 } \\
\quad \operatorname{deg} \text { C }\end{array}$ & $\begin{array}{l}\text { Control T4 } \\
\operatorname{deg} C\end{array}$ & $\begin{array}{l}\text { Cyl Bottom T5 } \\
\operatorname{deg} C\end{array}$ & $\begin{array}{c}\text { Cone Midpoint T6 } \\
\operatorname{deg} \text { C }\end{array}$ & $\begin{array}{c}\text { Cone Midpoint T7 } \\
\operatorname{deg} C\end{array}$ & $\begin{array}{c}\text { Drain Top T8 } \\
\operatorname{deg} \text { C }\end{array}$ & $\begin{array}{l}\text { XP20 } \\
\text { volts }\end{array}$ & $\begin{array}{l}\text { XP20 } \\
\text { amps }\end{array}$ & $\begin{array}{l}\text { XP20 } \\
\text { KVA }\end{array}$ & $\begin{array}{l}\mathrm{XP2O} \\
\mathrm{KHz}\end{array}$ & $\begin{array}{l}\text { XP5 } \\
\text { volts }\end{array}$ & $\begin{array}{l}\text { XP5 } \\
\text { amps }\end{array}$ & $\begin{array}{l}\text { XP5 } \\
\text { KVA }\end{array}$ & $\begin{array}{l}\text { XP5 } \\
\text { KHZ }\end{array}$ \\
\hline 1 & 19 & 18 & 17 & 21 & 20 & 18 & 17 & 17 & 35 & 2 & 0.07 & 350 & 2 & 0 & 0 & 0 \\
\hline 10 & 27 & 81 & 105 & 103 & 96 & 95 & 87 & 87 & 70 & 8 & 0.56 & 96 & 69 & 4 & 0 & 0.27 \\
\hline 20 & 73 & 131 & 154 & 154 & 151 & 150 & 146 & 147 & 70 & 9 & 0.63 & 97 & 68 & 4 & 0 & 0.27 \\
\hline 30 & 136 & 163 & 187 & 188 & 188 & 189 & 187 & 182 & 70 & 9 & 0.63 & 97 & 68 & 4 & 0 & 0.27 \\
\hline 40 & 151 & 210 & 258 & 261 & 259 & 252 & 243 & 238 & 93 & 12 & 1.11 & 97 & 86 & 6 & 0 & 0.51 \\
\hline 50 & 167 & 273 & 335 & 343 & 343 & 332 & 325 & 315 & 97 & 13 & 1.26 & 97 & 91 & 6 & 0 & 0.54 \\
\hline 60 & 201 & 336 & 411 & 420 & 424 & 406 & 400 & 392 & 103 & 13 & 1.33 & 97 & 95 & 6 & 0 & 0.57 \\
\hline 70 & 250 & 396 & 483 & 496 & 495 & 475 & 468 & 458 & 110 & 14 & 1.54 & 97 & 99 & 7 & 0 & 0.69 \\
\hline 80 & 315 & 458 & 557 & 569 & 570 & 544 & 537 & 519 & 117 & 15 & 1.75 & 97 & 107 & 7 & 0 & 0.74 \\
\hline 90 & 377 & 522 & 631 & 644 & 644 & 616 & 609 & 590 & 124 & 16 & 1.98 & 97 & 113 & 7 & 0 & 0.79 \\
\hline 100 & 453 & 586 & 717 & 729 & 702 & 680 & 689 & 665 & 131 & 17 & 2.22 & 97 & 119 & 7 & 212 & 0.83 \\
\hline 110 & 563 & 668 & 809 & 821 & 824 & 782 & 781 & 754 & 137 & 19 & 2.6 & 97 & 126 & 9 & 240 & 1.13 \\
\hline 120 & 681 & 723 & 893 & 916 & 905 & 858 & 859 & 836 & 144 & 20 & 2.88 & 98 & 131 & 9 & 213 & 1.17 \\
\hline 130 & 778 & 780 & 959 & 976 & 967 & 917 & 916 & 890 & 151 & 20 & 3.02 & 97 & 135 & 8 & 228 & 1.08 \\
\hline 140 & 873 & 831 & 1013 & 1034 & 1024 & 972 & 970 & 940 & 157 & 22 & 3.45 & 97 & 139 & 9 & 235 & 1.25 \\
\hline 150 & 959 & 881 & 1051 & 1076 & 1071 & 1022 & 1018 & 989 & 164 & 23 & 3.77 & 98 & 147 & 9 & 229 & 1.32 \\
\hline 160 & 1048 & 936 & 1064 & 1102 & 1109 & 1064 & 1057 & 1029 & 171 & 24 & 4.1 & 98 & 153 & 10 & 252 & 1.53 \\
\hline 170 & 1109 & 1013 & 1078 & 1118 & 1139 & 1103 & 1086 & 1061 & 177 & 24 & 4.24 & 98 & 157 & 11 & 225 & 1.72 \\
\hline 180 & 1127 & 1101 & 1166 & 1151 & 1162 & 1142 & 1110 & 1082 & 184 & 26 & 4.78 & 98 & 163 & 11 & 237 & 1.79 \\
\hline 190 & 1147 & 1165 & 1233 & 1214 & 1218 & 1189 & 1147 & 1113 & 190 & 27 & 5.13 & 98 & 167 & 11 & 237 & 1.83 \\
\hline 200 & 1224 & 1211 & 1277 & 1254 & 1262 & 1235 & 1205 & 1180 & 197 & 28 & 5.51 & 98 & 170 & 13 & 225 & 2.21 \\
\hline 210 & 1281 & 1264 & 1335 & 1307 & 1318 & 1282 & 1251 & 1229 & 203 & 30 & 6.09 & 98 & 181 & 12 & 217 & 2.17 \\
\hline 220 & 1363 & 1315 & 1386 & 1352 & 1367 & 1340 & 1314 & 1298 & 210 & 31 & 6.51 & 98 & 187 & 12 & 240 & 2.24 \\
\hline 230 & 1424 & 1359 & 1433 & 1393 & 1410 & 1389 & 1371 & 1359 & 216 & 31 & 6.69 & 98 & 190 & 13 & 241 & 2.47 \\
\hline 240 & 1420 & 1368 & 1447 & 1405 & 1422 & 1378 & 1340 & 1328 & 219 & 32 & 7 & 98 & 191 & 13 & 251 & 2.48 \\
\hline 250 & 1401 & 1362 & 1448 & 1404 & 1418 & 1365 & 1324 & 1310 & 221 & 32 & 7.07 & 98 & 191 & 13 & 251 & 2.48 \\
\hline 260 & 1397 & 1361 & 1449 & 1405 & 1418 & 1362 & 1320 & 1306 & 223 & 32 & 7.13 & 98 & 191 & 13 & 251 & 2.48 \\
\hline 270 & 1396 & 1361 & 1449 & 1404 & 1416 & 1361 & 1319 & 1304 & 222 & 32 & 7.1 & 98 & 191 & 13 & 251 & 2.48 \\
\hline 280 & 1395 & 1360 & 1449 & 1404 & 1415 & 1360 & 1317 & 1303 & 223 & 32 & 7.13 & 98 & 191 & 13 & 251 & 2.48 \\
\hline 290 & 1394 & 1360 & 1448 & 1403 & 1414 & 1360 & 1317 & 1302 & 222 & 32 & 7.1 & 98 & 191 & 13 & 251 & 2.48 \\
\hline 300 & 1394 & 1360 & 1449 & 1402 & 1414 & 1359 & 1317 & 1302 & 223 & 32 & 7.13 & 98 & 191 & 13 & 251 & 2.48 \\
\hline 310 & 1393 & 1360 & 1449 & 1402 & 1414 & 1359 & 1316 & 1301 & 222 & 32 & 7.1 & 98 & 191 & 13 & 251 & 2.48 \\
\hline 320 & 1393 & 1360 & 1448 & 1401 & 1413 & 1359 & 1316 & 1301 & 223 & 32 & 7.13 & 98 & 191 & 13 & 251 & 2.48 \\
\hline 330 & 1393 & 1361 & 1448 & 1401 & 1412 & 1359 & 1316 & 1300 & 223 & 32 & 7.13 & 98 & 191 & 13 & 251 & 2.48 \\
\hline 340 & 1393 & 1360 & 1449 & 1401 & 1413 & 1359 & 1316 & 1300 & 223 & 32 & 7.13 & 98 & 191 & 13 & 251 & 2.48 \\
\hline 350 & 1393 & 1360 & 1448 & 1400 & 1412 & 1359 & 1315 & 1300 & 223 & 32 & 7.13 & 98 & 191 & 13 & 251 & 2.48 \\
\hline 360 & 1393 & 1360 & 1448 & 1399 & 1412 & 1359 & 1315 & 1300 & 222 & 32 & 7.1 & 98 & 191 & 13 & 251 & 2.48 \\
\hline 370 & 1393 & 1360 & 1448 & 1399 & 1412 & 1358 & 1315 & 1299 & 223 & 32 & 7.13 & 98 & 191 & 13 & 251 & 2.48 \\
\hline 380 & 1393 & 1360 & 1448 & 1399 & 1411 & 1358 & 1315 & 1299 & 223 & 32 & 7.13 & 98 & 191 & 13 & 251 & 2.48 \\
\hline 390 & 1393 & 1360 & 1447 & 1399 & 1412 & 1358 & 1315 & 1299 & 222 & 32 & 7.1 & 98 & 191 & 13 & 251 & 2.48 \\
\hline 400 & 1393 & 1360 & 1448 & 1399 & 1412 & 1358 & 1315 & 1298 & 222 & 32 & 7.1 & 98 & 191 & 13 & 251 & 2.48 \\
\hline 410 & 1394 & 1360 & 1448 & 1399 & 1412 & 1359 & 1316 & 1301 & 223 & 32 & 7.13 & 98 & 191 & 13 & 251 & 2.48 \\
\hline 420 & 1419 & 1369 & 1451 & 1405 & 1424 & 1377 & 1332 & 1308 & 223 & 32 & 7.13 & 98 & 191 & 13 & 251 & 2.48 \\
\hline 430 & 1321 & 1275 & 1345 & 1303 & 1319 & 1275 & 1226 & 1211 & 193 & 28 & 5.4 & 98 & 191 & 13 & 251 & 2.48 \\
\hline 440 & 1140 & 1103 & 1163 & 1129 & 1141 & 1099 & 1057 & 1044 & 159 & 22 & 3.49 & 98 & 191 & 13 & 251 & 2.48 \\
\hline 450 & 944 & 915 & 964 & 937 & 946 & 909 & 873 & 862 & 126 & 18 & 2.26 & 97 & 191 & 13 & 251 & 2.48 \\
\hline 460 & 125 & 720 & 753 & 732 & 737 & 706 & 678 & 669 & 93 & 13 & 1.2 & 97 & 191 & 13 & 251 & 2.48 \\
\hline
\end{tabular}

